Florida International University FIU Digital Commons

10-26-2009

\title{
An Integrated Flow and Transport Model to Study the Impact of Mercury Remediation Strategies for East Fork Poplar Creek Watershed, Oak Ridge, Tennessee
}

Stephanie Long

Florida International University, slong001@fiu.edu

DOI: $10.25148 /$ etd.FI09121604

Follow this and additional works at: https://digitalcommons.fiu.edu/etd

Part of the Environmental Engineering Commons

\section{Recommended Citation}

Long, Stephanie, "An Integrated Flow and Transport Model to Study the Impact of Mercury Remediation Strategies for East Fork Poplar Creek Watershed, Oak Ridge, Tennessee" (2009). FIU Electronic Theses and Dissertations. 141.

https://digitalcommons.fiu.edu/etd/141 
FLORIDA INTERNATIONAL UNIVERSITY

Miami, Florida

\section{AN INTEGRATED FLOW AND TRANSPORT MODEL TO STUDY THE \\ IMPACT OF MERCURY REMEDIATION STRATEGIES FOR EAST FORK POPLAR \\ CREEK WATERSHED, OAK RIDGE, TENNESSEE}

A thesis submitted in partial fulfillment of the

requirements for the degree of

MASTER OF SCIENCE

in

ENVIRONMENTAL ENGINEERING

by

Stephanie Long

2009 
To: Dean Amir Mirmiran

College of Engineering and Computing

This thesis, written by Stephanie Long, and entitled An Integrated Flow and Transport Model to Study the Impact of Mercury Remediation Strategies for East Fork Poplar Creek Watershed, Oak Ridge, Tennessee, having been approved in respect to style and intellectual content, is referred to you for judgment.

We have read this thesis and recommend that it be approved.

Georgio Tachiev

Hector Fuentes

\section{Fernando Miralles-Wilhelm, Major Professor}

Date of Defense: October 26, 2009

The thesis of Stephanie Long is approved.

Dean Amir Mirmiran
College of Engineering and Computing

Florida International University, 2009 


\section{ACKNOWLEDGMENTS}

I would like to thank my committee for all of their guidance and knowledge, Georgio for his mentoring and perspective, my peers for their sympathy and friendship, and most importantly my amazing parents for their unwavering support and love. 


\author{
ABSTRACT OF THE THESIS \\ AN INTEGRATED FLOW AND TRANSPORT MODEL TO STUDY THE \\ IMPACT OF MERCURY REMEDIATION STRATEGIES FOR EAST FORK POPLAR \\ CREEK WATERSHED, OAK RIDGE, TENNESSEE \\ by
}

Stephanie Long

Florida International University, 2009

Miami, Florida

Professor Fernando Miralles-Wilhelm, Major Professor

An integrated flow and transport model using MIKE SHE/MIKE 11 software was developed to predict the flow and transport of mercury, $\mathrm{Hg}(\mathrm{II})$, under varying environmental conditions. The model analyzed the impact of remediation scenarios within the East Fork Poplar Creek watershed of the Oak Ridge Reservation with respect to downstream concentration of mercury. The numerical simulations included the entire hydrological cycle: flow in rivers, overland flow, groundwater flow in the saturated and unsaturated zones, and evapotranspiration and precipitation time series. Stochastic parameters and hydrologic conditions over a five year period of historical hydrological data were used to analyze the hydrological cycle and to determine the prevailing mercury transport mechanism within the watershed. Simulations of remediation scenarios revealed that reduction of the highly contaminated point sources, rather than general remediation of the contaminant plume, has a more direct impact on downstream mercury concentrations. 


\section{TABLE OF CONTENTS}

CHAPTER

PAGE

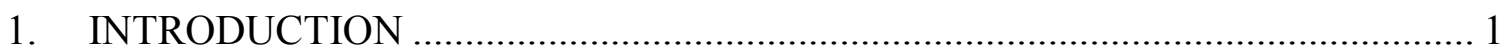

$1.1 \quad$ Research objectives and hypothesis .........................................................

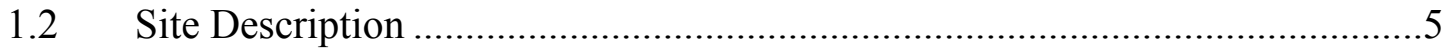

2. DEVELOPMENT OF THE FLOW MODEL_.................................................... 15

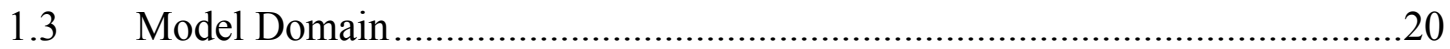

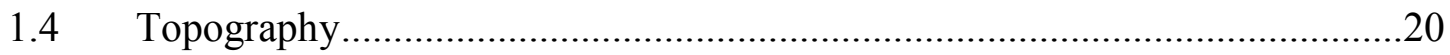

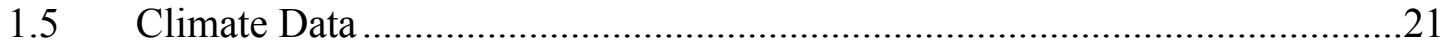

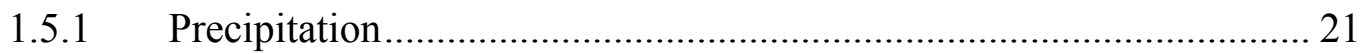

1.5.2 Evapotranspiration...................................................................... 22

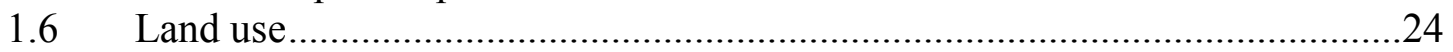

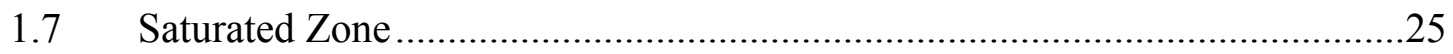

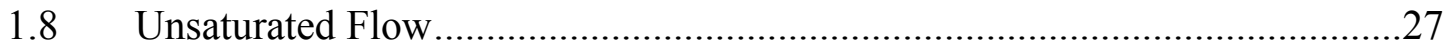

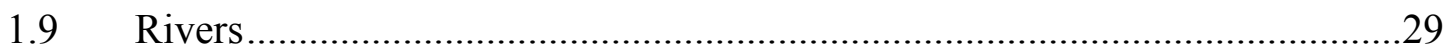

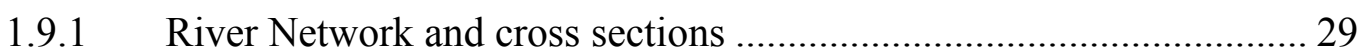

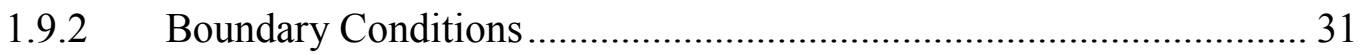

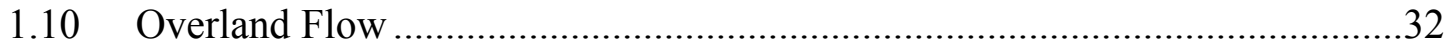

1.11 Calibration of the Hydrological Model …………........................................34

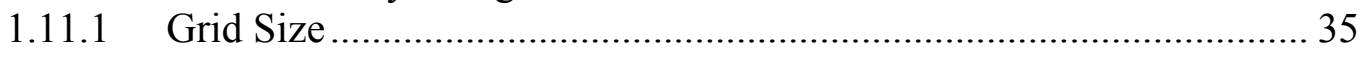

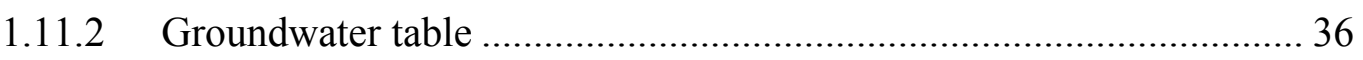

1.11.3 Hydrologic simulations................................................................. 38

3. DEVELOPMENT OF THE MERCURY TRANSPORT MODEL ........................... 46

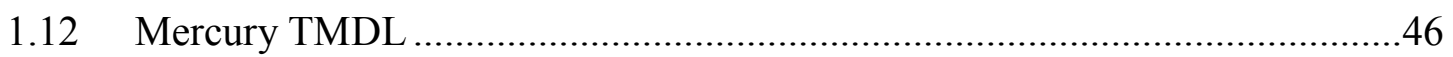

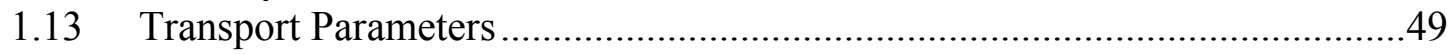

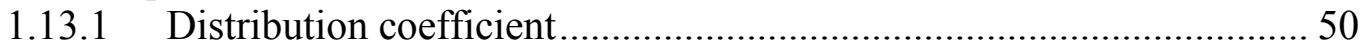

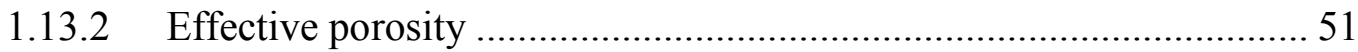

1.13.3 Matrix porosity ................................................................................. 51

1.13.4 Dual porosity transport ………………………………………..... 52

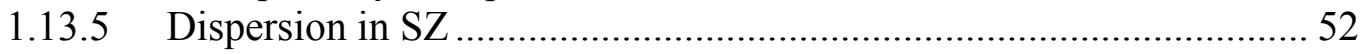

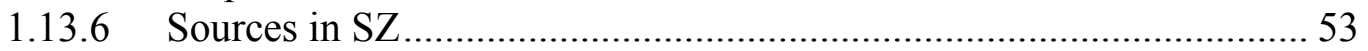

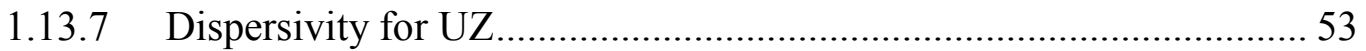

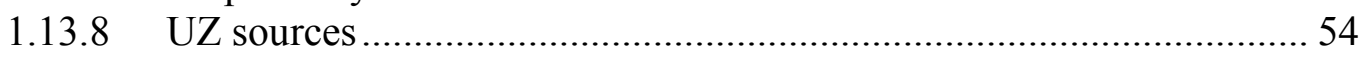

1.13.9 Dispersion in overland flow ………………………………….... 55

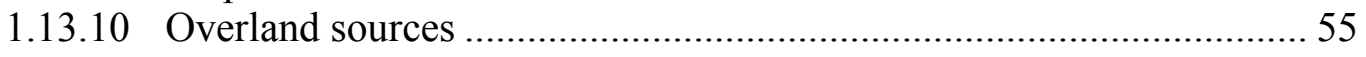

1.14 Mercury Transport Model Calibration ………………..................................55

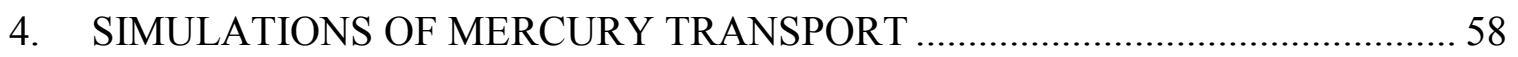

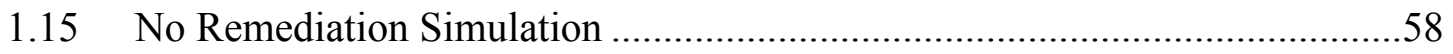

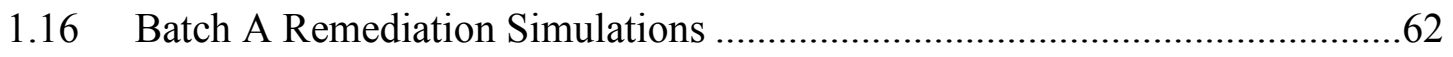

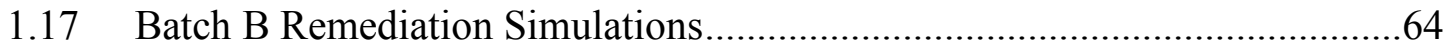




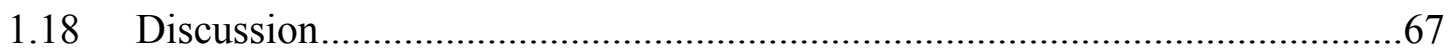

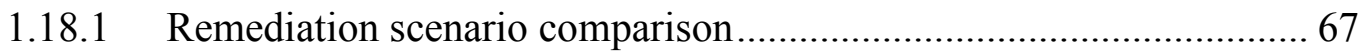

1.18.2 Mercury transport timeseries ........................................................... 69

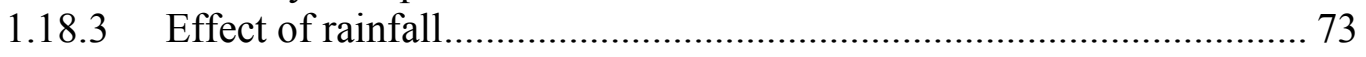

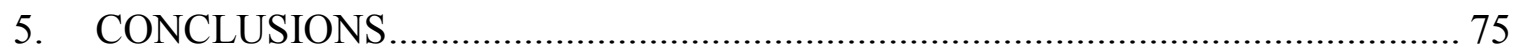

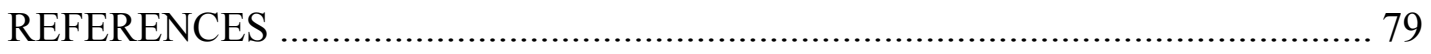

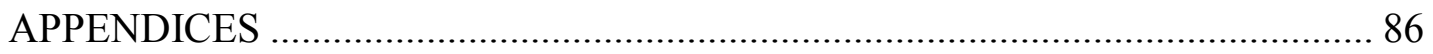




\section{LIST OF TABLES}

TABLE

PAGE

Table 1 NLCD 2001 Land use classification and Manning's number........................... 13

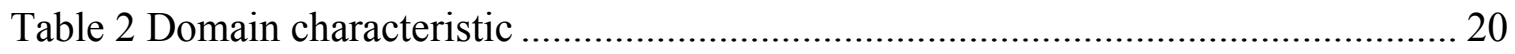

Table 3 Vegetation data and Manning's number ...................................................... 24

Table 4 Van Genuchten's soil hydraulic parameters ............................................. 28

Table 5 Boundary conditions for select rivers ..................................................... 31

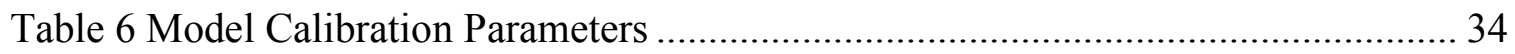

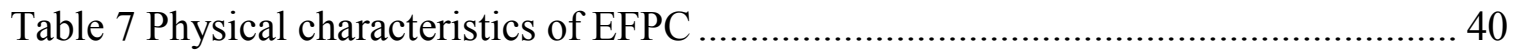

Table 8 Transport parameters used in the model ................................................. 49

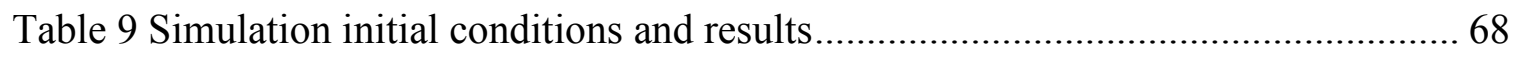

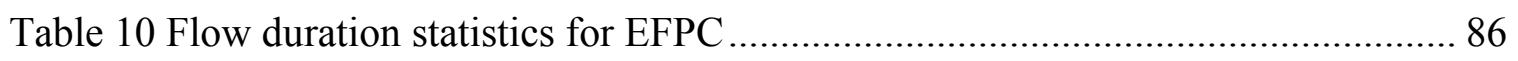

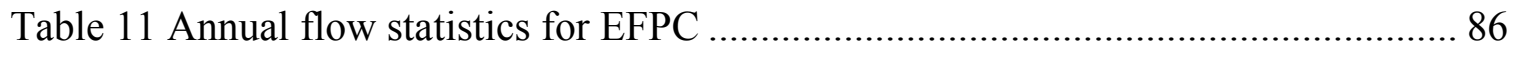

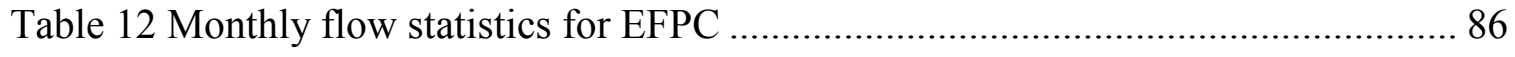

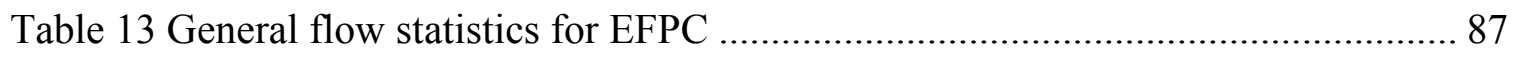

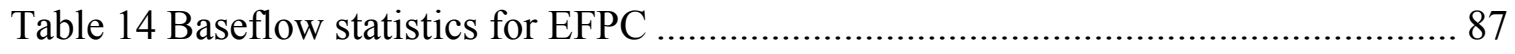

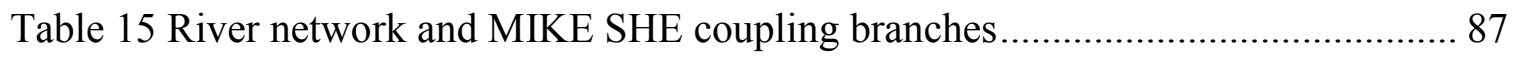




\section{LIST OF FIGURES}

FIGURE

PAGE

Figure 1 Total mercury concentration $(\mathrm{mg} / \mathrm{kg})$ used in the model (modified from

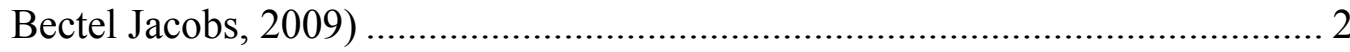

Figure 2 Location of the Oak Ridge Reservation (ATSDR, 2006)................................ 5

Figure 3 Lower Clinch River watershed in Tennessee ........................................... 6

Figure 4 DEM of East Fork Poplar Creek watershed ............................................ 7

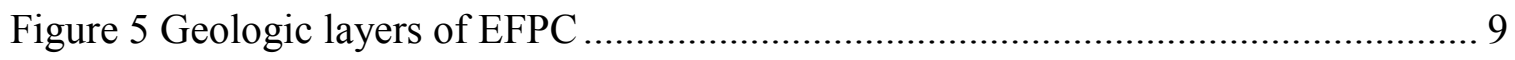

Figure 6 Primary streams within EFPC watershed .................................................. 12

Figure 7 Percent imperviousness for EFPC watershed........................................... 14

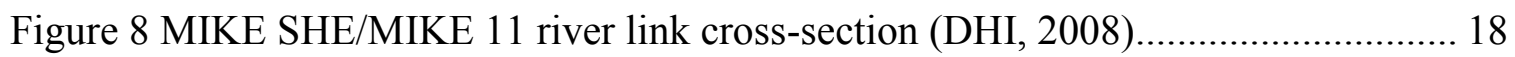

Figure 9 Topography of the study area represented in the software ............................. 21

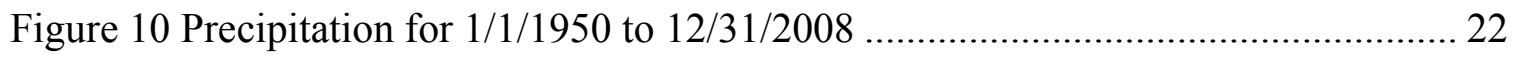

Figure 11 Discretization of landuse data used for the hydrological model .................... 25

Figure 12 River Network and domain with cross section locations, boundaries

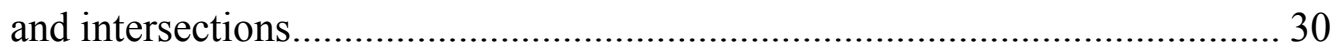

Figure 13 Calculated groundwater table elevations............................................. 36

Figure 14 Observed and computed values for levels in GW-281 ............................... 37

Figure 15 Observed and computed values for levels in GW-294 ............................... 37

Figure 16 Observed and computed values for levels in GW-276 .............................. 38

Figure 17 Location of USGS Stations and DOE stations used for data comparison ........ 39

Figure 18 USGS stations used for calibration of discharges in EFPC streams .............. 40

Figure 19 Computed and observed discharge values at USGS station $03238230 \ldots \ldots \ldots . . .41$

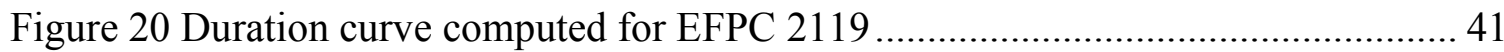


Figure 21 Location of USGS station 03538235 and Station 17 (EFK 23.4) 42

Figure 22 Computed and measured discharges at EFPC 3209, EFK 23.4, and USGS station 03538235 .

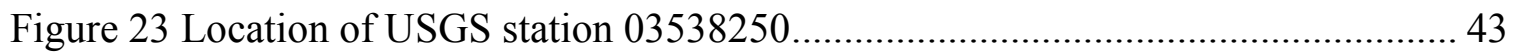

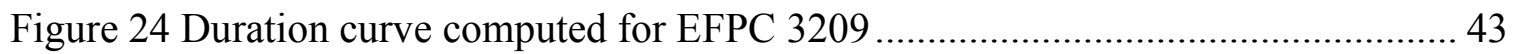

Figure 25 Computed and measured discharges at EFPC 20267 and USGS

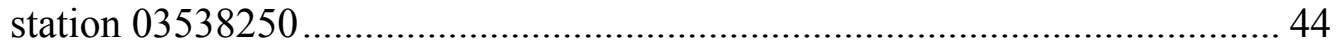

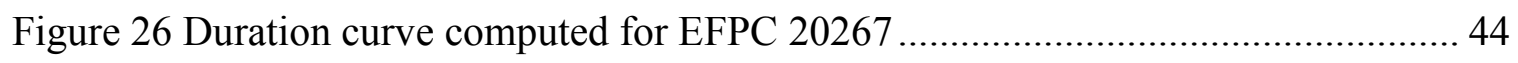

Figure 27 Cumulative distribution of computed and observed discharge at EFPC 20267 45

Figure 28 Boxplot of Computed and observed discharge at EFPC 20267 ..................... 45

Figure 29 Observed and computed mercury concentration at Station $17 \ldots \ldots \ldots \ldots \ldots \ldots \ldots . . . . . . . . . . . .66$

Figure 30 Observed and computed mercury at the outfall for existing conditions........... 56

Figure 31 Flow Duration Curve at Station 17 (1997-2007)........................................ 57

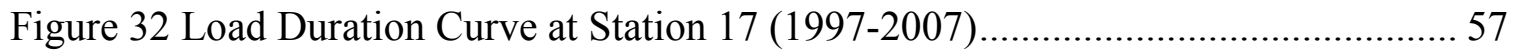

Figure 33 Measured mercury (mg/L) and discharge (cfs) at Station 17 ....................... 59

Figure 34 Initial concentrations for the no-remediation simulation ............................. 59

Figure 35 Simulated distribution of overland mercury transport mass per unit area....... 60

Figure 36 Observed and calculated mercury concentrations at Station 17 during year 2002 .

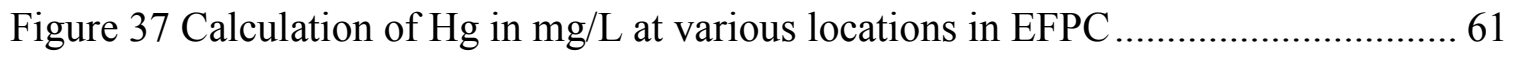

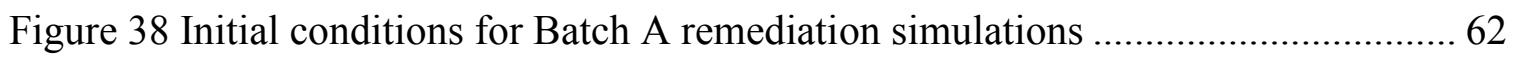

Figure $39 \mathrm{Hg}$ concentrations (mg/L) at the EFPC outfall for the Batch A simulations

Figure $40 \mathrm{Hg}$ Accumulated Mass $(\mathrm{kg})$ at the EFPC outfall for the Batch A simulations 
Figure 41 Initial conditions for Batch B remediation simulations............................... 65

Figure $42 \mathrm{Hg}$ concentrations $(\mathrm{mg} / \mathrm{L})$ at the EFPC outfall for Batch B simulations.......... 66

Figure $43 \mathrm{Hg}$ Accumulated Mass (kg) at the EFPC outfall for Batch B simulations ....... 66

Figure 44 Comparison of percent removal and percent reduction................................ 68

Figure 45 Mercury storage rates in SZ, UZ, and OL zone for Batch A simulations ........ 70

Figure 46 Exchange rates between hydrologic zones for Batch A simulations............... 71

Figure 47 Mercury storage rates in SZ, UZ, and OL zone for Batch B simulations ........ 72

Figure 48 Exchange rates between hydrologic zones for Batch B simulations ................ 73

Figure 49 The affect of rainfall on mercury transport to the SZ for September .............. 74

Figure 50 The affect of rainfall on mercury transport to the UZ for February …............ 75

Figure 51 Typical stratigraphic section for EFPC watershed (ORNL, 1992)................. 91 


\section{LIST OF ACRONYMS}

\begin{tabular}{|c|c|}
\hline $\mathrm{AD}$ & Advection-Dispersion \\
\hline ATSDR & Agency for Toxic Substances and Disease Registry \\
\hline $\mathrm{CT}$ & Cumulative Time \\
\hline DEM & Digital Elevation Model \\
\hline DHI & Danish Hydraulic Institute \\
\hline EFPC & East Fork Poplar Creek \\
\hline EPA & Environmental Protection Agency \\
\hline ET & Evapotranspiration \\
\hline EUM & Engineering Unit Management \\
\hline GIS & Geographic Information System \\
\hline HD & Hydrodynamic \\
\hline HUC & Hydrologic Unit Code \\
\hline IDW & Inverse Distance Weighted \\
\hline LAI & Leaf Area Index \\
\hline $\mathrm{MCT}$ & Maximum Continuous Time \\
\hline NAD & North American Datum \\
\hline NHD & National Hydrography Dataset \\
\hline NLCD & National Land Cover Dataset \\
\hline NOAA & National Oceanic and Atmospheric Administration \\
\hline $\mathrm{OC}$ & Open Channel \\
\hline $\mathrm{OL}$ & Overland Flow \\
\hline OREIS & Oak Ridge Environmental Information System \\
\hline
\end{tabular}




$\begin{array}{ll}\text { ORNL } & \text { Oak Ridge National Laboratory } \\ \text { ORR } & \text { Oak Ridge Reservation } \\ \text { RD } & \text { Root Depth } \\ \text { SZ } & \text { Saturated Zone } \\ \text { TDEC } & \text { Tennessee Department of Environment and Conservation } \\ \text { TMDL } & \text { Total Maximum Daily Load } \\ \text { USGS } & \text { United States Geologic Survey } \\ \text { UZ } & \text { Unsaturated Zone } \\ \text { WCS } & \text { Watershed Characterization System } \\ \text { WOC } & \text { White Oak Creek }\end{array}$




\section{INTRODUCTION}

The environment in the vicinity of the Y-12 National Security Complex and East Fork Poplar Creek (EFPC) watershed at the Oak Ridge Reservation (ORR) has been contaminated by thousands of pounds of mercury as a result of nuclear processing activities. The Y-12 complex is situated in the northeast section of the EFPC watershed; a watershed of about $77 \mathrm{sq} \mathrm{km}(19,000$ acres). In 1943, the complex served as the first offensive of the Manhattan Project with the primary mission of separating uranium-235 from natural uranium via electromagnetic separation (Y-12 Fact Sheet, 2008). Additionally, Y-12 used mercury to separate isotopes of lithium associated with thermonuclear weapons production at the site. It is estimated that over one hundred metric tons of mercury was released during the 1950's and 60's in the Oak Ridge region (Turner, 1985). As a result, mercury contamination is seemingly ubiquitous in the Y-12 watershed and in the upper reaches of EFPC and has been identified as a key contamination in soil, sediment, surface water, groundwater, buildings, and other infrastructure (Han et al., 2006). Studies have shown that contamination from Y-12 (over $77,000 \mathrm{~kg}$ of $\mathrm{Hg}$ ) is present in the upper 10 feet of soils along a 15-mile long stretch of EFPC (Han et al., 2006). Figure 1 shows a map of the contamination in the saturated zone within the vicinity of the Y-12 complex. Mercury loading on East Fork Poplar Creek is carried downstream to Poplar Creek, the Clinch River, and Watts Bar Reservoir; affecting over 50 river miles in length and 2,336 lake acres in surface area. In 2008 the State of Tennessee listed portions of EFPC as not supporting designated use classifications (including fish and aquatic life, irrigation, livestock watering and wildlife, and recreation) due to mercury contamination. 


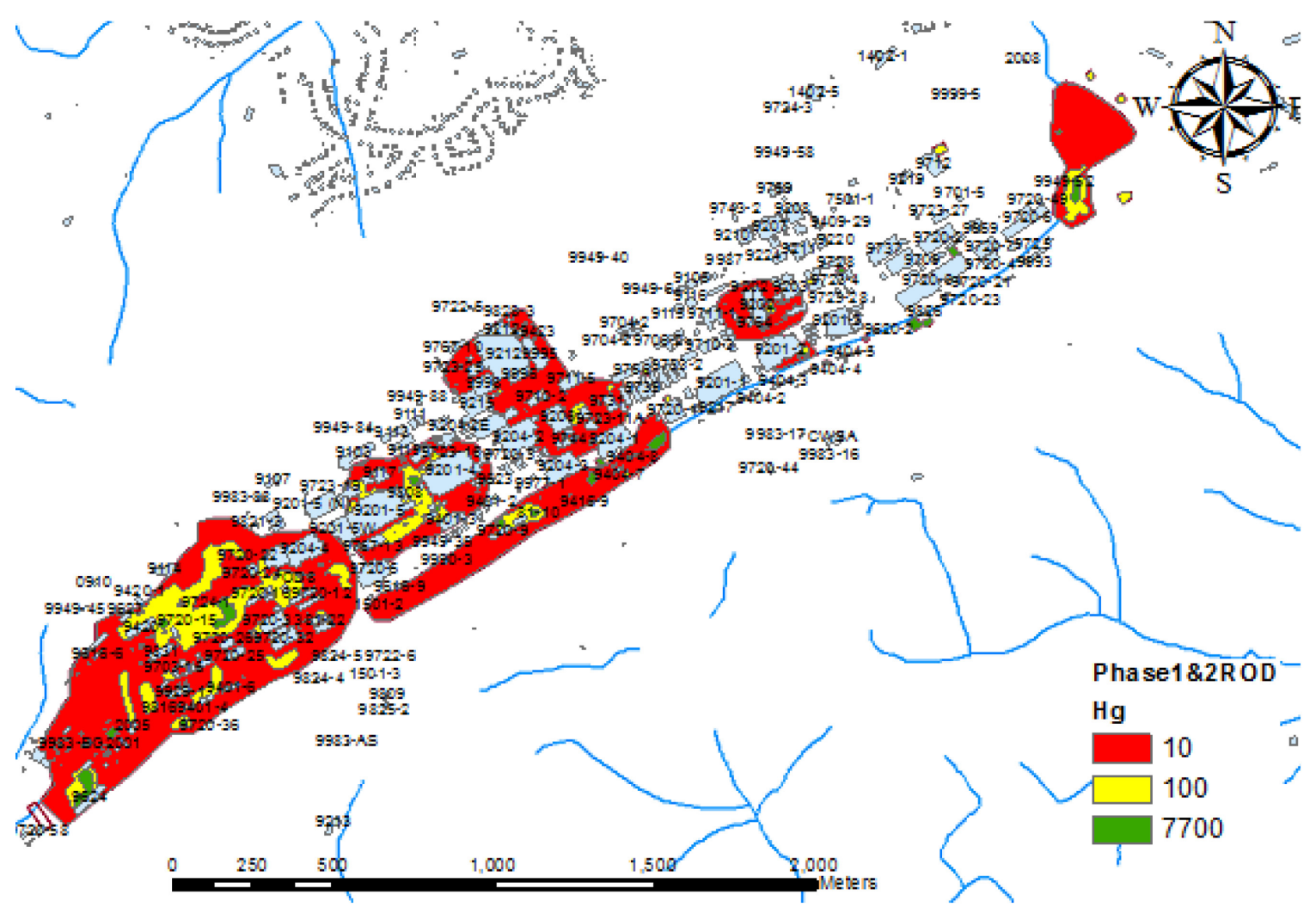

Figure 1 Total mercury concentration $(\mathrm{mg} / \mathrm{kg})$ used in the model (modified from Bectel Jacobs, 2009)

The transport of mercury in the watershed can be determined using advanced watershed modeling software. The Danish Hydraulic Institute's (DHI) MIKE SHE software is an integrated surface water and groundwater software that can simulate the entire land phase of the hydrologic cycle. The model offers the ability to input relevant hydrologic parameters to create a watershed model which is capable of simulating flow in the subsurface (saturated and unsaturated zones) and surface sub-domains (overland and river) and contaminant transport and exchange between various sub-domains using an advection-dispersion module.

In a study performed by Camp Dresser \& McKee in 2001, several integrated watershed modeling tools were evaluated based on performance. The primary objective 
of the evaluation was to rank current technologies which effectively integrated groundwater and surface water simulations. The results of the evaluation gave MIKE SHE the highest ranking, with high grades for GIS integration, intermodal connectivity, minimum model limitations, and platform flexibility of the operating system, and low grades for cost and limited code availability. MODFLOW (a 3-D groundwater model developed by the USGS) and DYNFLOW (a finite element model from Camp Dresser and McKee, Inc.) were also ranked highly for the open source availability of the models and their codes; however, these models lacked GIS integration and had some model limitations. The study addressed each model with the focus on the interaction of surface water and groundwater systems where changes in one system have a significant influence on the other and, in fact, change in response to changes in the other. If one system is modeled independently, a technique must be used to represent changes in the other system in the model; this process generally incurs model limitations. A more refined and natural approach is to model both the surface water and groundwater systems as a single integrated system, where mutual interactions during process fluctuations are modeled (Camp Dresser \& McKee, 2001).

MIKE SHE can simulate all the hydrologic processes using physics-based methods or combine conceptual and physics-based methods-based on data availability and project needs. MIKE SHE's process-based framework allows each process to be solved at its own relative spatial and temporal scale. Temporal relativity is important when modeling quick responding parameters such as overland flow which responds quickly to rainfall events, with groundwater flow which reacts much slower (Graham and Butts, 2005). 


\subsection{Research objectives and hypothesis}

The research hypothesis is that a more effective cleanup effort of mercury contaminated soil and groundwater at the Y-12 Complex in EFPC watershed will be achieved by a control source strategy focused on remediating existing hot spots of mercury contamination, rather than through a strategy focused on capturing and treating contaminated groundwater. The research hypothesis is supported by the development and implementation of a model as outlined by the objectives.

The primary objective of this research is to develop an integrated flow and transport model which is capable of analyzing remediation strategies by predicting the transport of

mercury in the soil, groundwater and surface water in the EFPC watershed at Oak Ridge Reservation (ORR). To achieve this objective, the research will be guided by the following processes.

\section{Characterize data}

II. Establish a conceptual model

III. Select and develop a numerical model

IV. Conduct sensitivity and uncertainty analysis

V. Simulate and analyze remediation scenarios

The specific tasks are to provide critical data on the spatial distribution of mercury species, to develop a three-dimensional model of the site, and to allow improved understanding of the fluxes across the model domain and the effect of hydrology on mercury transport. 


\subsection{Site Description}

East Fork Poplar Creek watershed is enclosed by the City of Oak Ridge in Tennessee. Oak Ridge is divided by Anderson County to the north and east and Roane County to the south and west. The entire city is about $233 \mathrm{sq} \mathrm{km}$, or $122 \mathrm{sq} \mathrm{km}$ in Anderson County and $112 \mathrm{sq} \mathrm{km}$ in Roane County. Figure 2 shows the location of ORR with the Y-12 complex is shown in the northeast corner.

For the EFPC watershed, the population as of 1990 was 15,483 people. This number is obtained from the Tennessee Block Centroid Populations produced by ESRI in 2000. Tennessee Block Centroid Populations provides population for each U.S. Census block centroid within Tennessee.

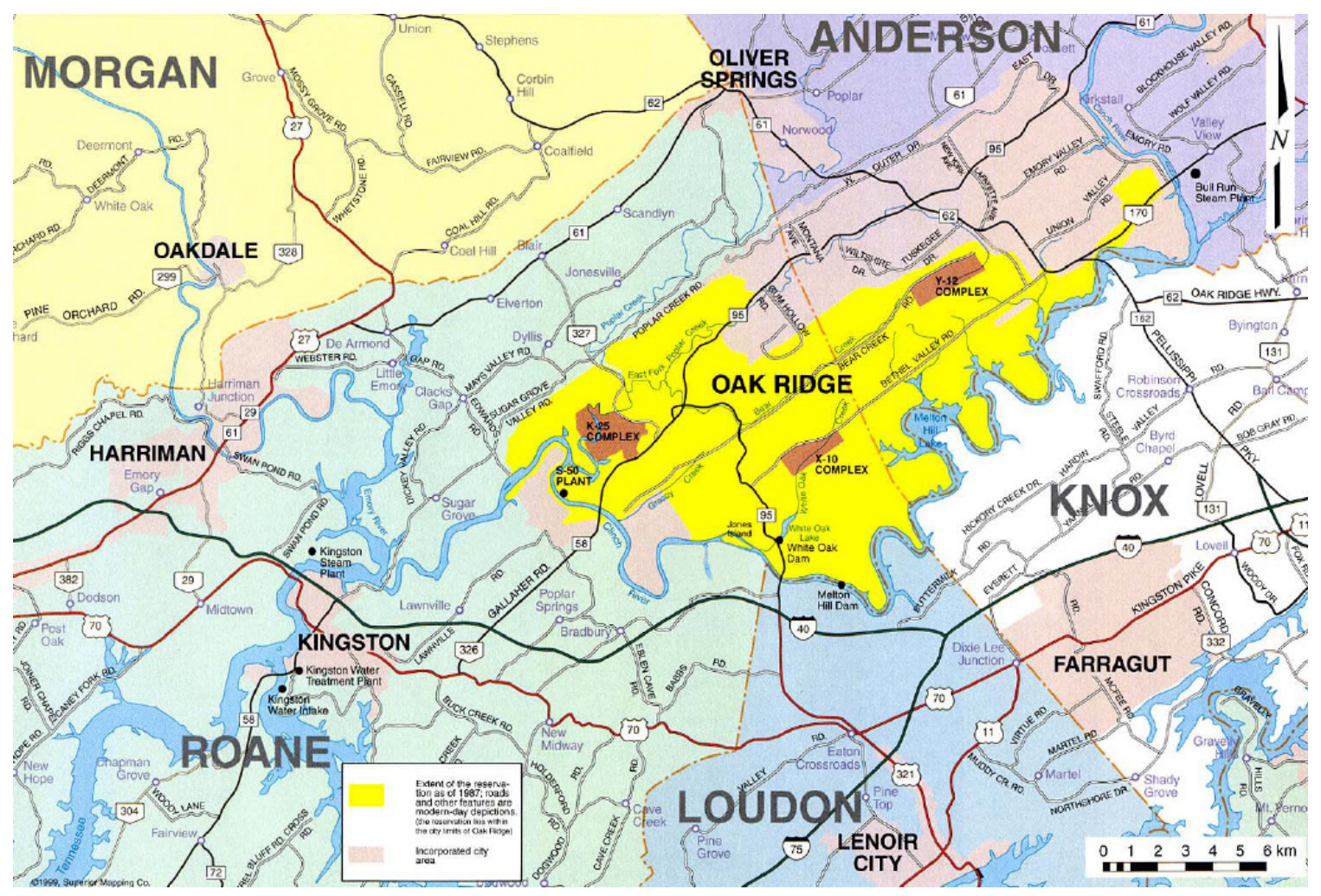

Figure 2 Location of the Oak Ridge Reservation (ATSDR, 2006) 
EFPC watershed is a sub-watershed within the Poplar Creek watershed, which is one of four sub-watersheds of the Lower Clinch River watershed in eastern Tennessee. Figure 3 shows the location of EFPC watershed within the Lower Clinch River watershed.

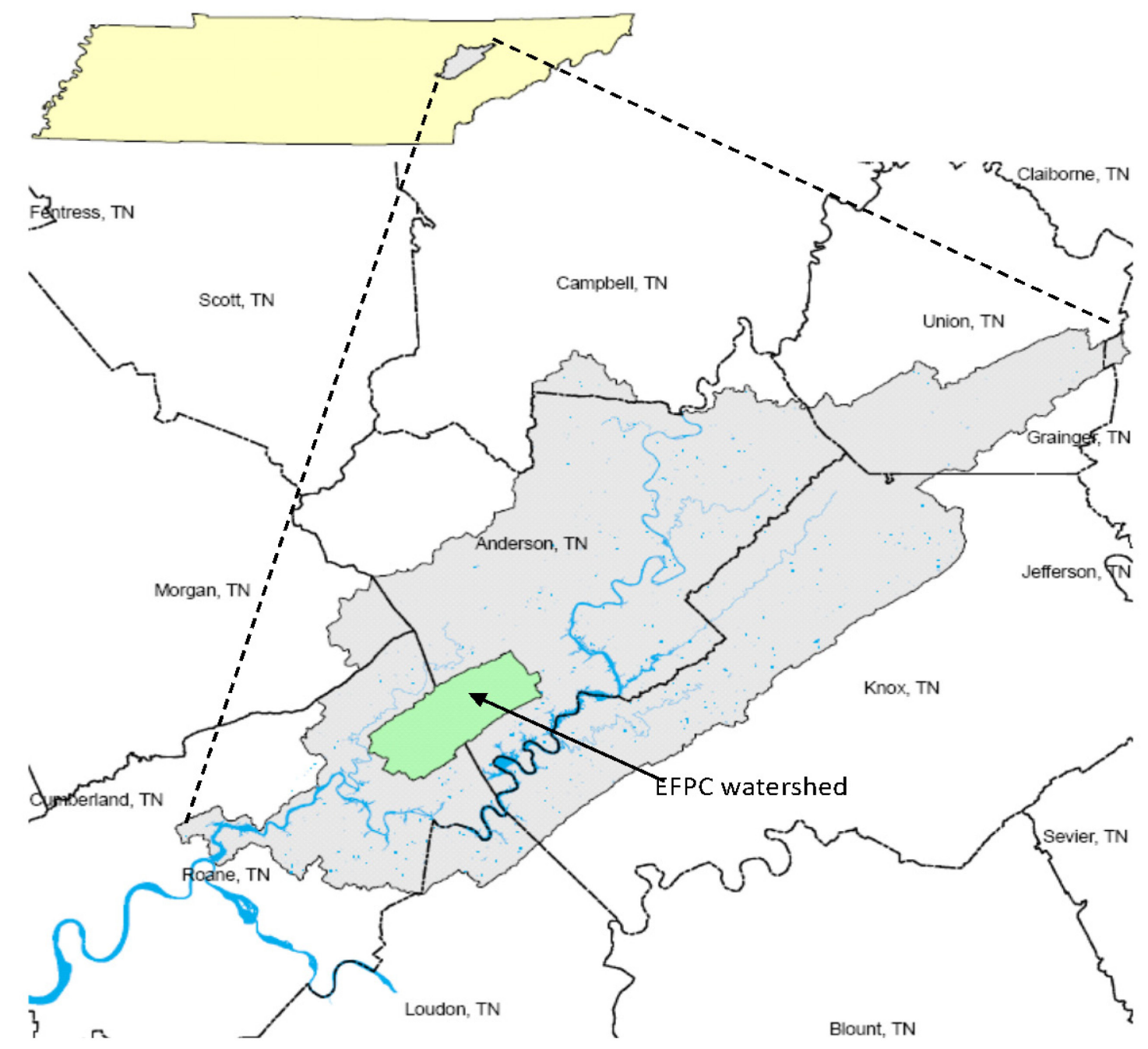

Figure 3 Lower Clinch River watershed in Tennessee

The City of Oak Ridge lays on relatively even surface at around 270 to 280 meters above mean sea level. The corduroy-like features of the Appalachian Valley and Ridge Province are visible from the Digital Elevation Model (DEM) of EFPC watershed in Figure 4. The Appalachian Valley and Ridge Province consists of alternating beds of hard 
and soft Paleozoic sedimentary rocks, which have been folded as a result of several continental collisions that formed the Appalachian chain and the Pangaea supercontinent 300 to 400 million years ago. Small rivers, such as East Fork Poplar Creek and Bear Creek, have taken their shape and direction from the valleys of the region where the soft sedimentary rock is easily eroded. Black Oak Ridge to the northwest and Chestnut Ridge to the southeast form the two major hydrologic boundaries of the EFPC watershed.

The EFPC watershed is characterized with high drainage density (EFPC has $29.3 \mathrm{mi}^{2}$ with $88 \mathrm{mi}$ of streams), implying increased surface runoff and steeper hydrographs.

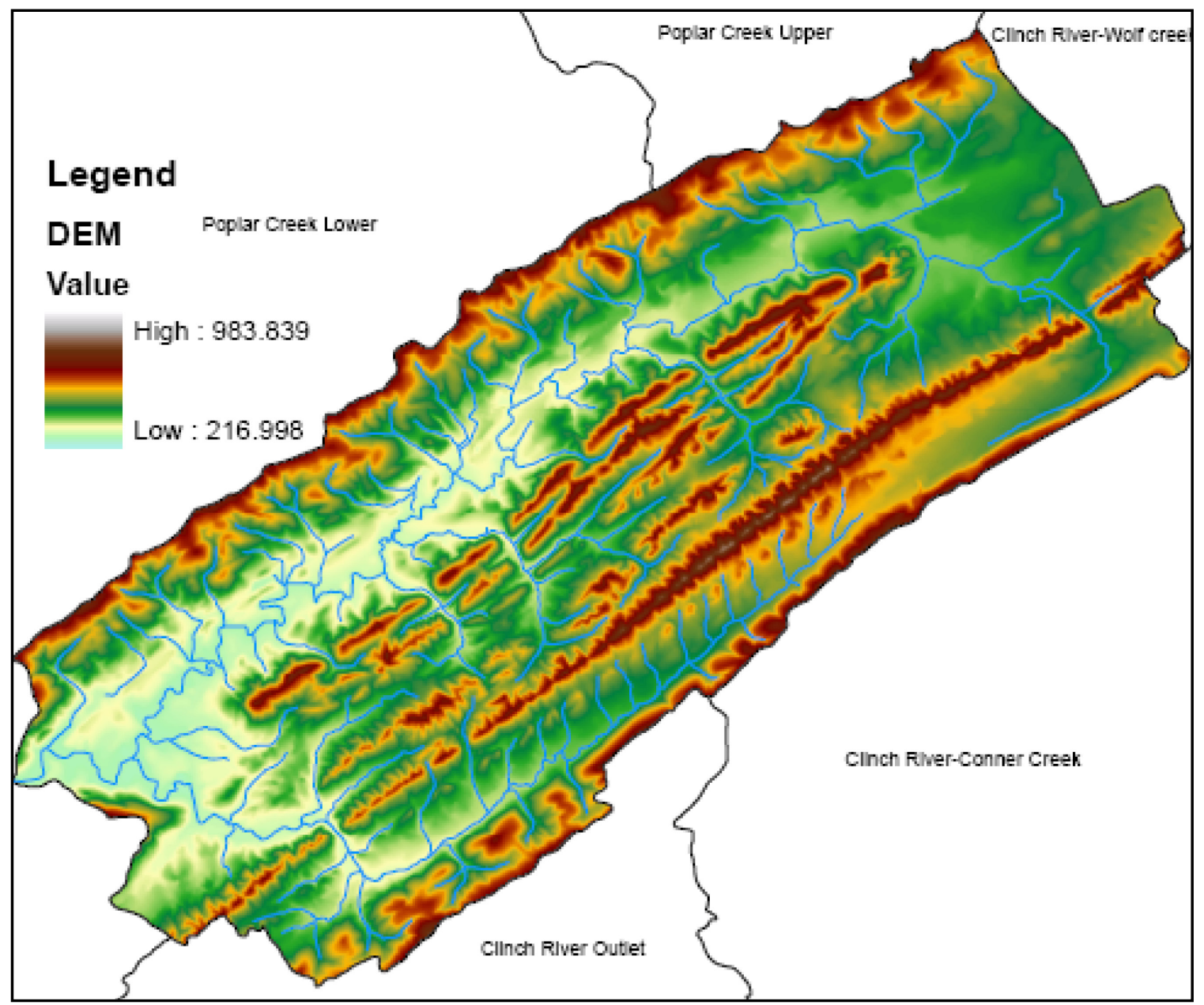

Figure 4 DEM of East Fork Poplar Creek watershed 
The watershed lies within the Ridge and Valley Level III ecoregion and contains two Level IV ecoregions as defined by the U.S. EPA National Health and Environmental Effects Research Laboratory (US EPA, 2007):

- The Southern Limestone /Dolomite Valleys and Low Rolling Hills predominately limestone or cherty dolomite in low rolling ridges and valleys

- The Southern Dissected Ridges and Knobs - crenulated, broken, or hummocky ridges; shale is common, mixed with other geologic materials

The defined ecoregions provide information about the geology which affects the subsurface hydrology. For example, the Level I ecoregion is characterized by nonhomogeneous subsurface hydrology, cavernous formations, etc.

Development of site-specific hydrological models requires knowledge of the ORR geology to adequately correlate the composition of soil material with soil hydrological properties. Soil geologic properties also provide basic information about factors controlling groundwater flow. Figure 5 shows the geological layers which have been identified according to the classification found in the Geologic Map of Tennessee, Tennessee Division of Geology, published by the Tennessee Division of Geology (Hardeman, 1966).

A variety of geological formations lies beneath ORR, including the primary group formations known as the Knox (OCk), Rome (Cr), Chickamauga (Och), and Conasuaga (Cc) Group Formations. Other geologic layers include the Sequatchie Formation (Os), Fort Payne Chert (Mfp), Rockwood Formation (Sr), Copper Ridge Dolomite (Ccr), Maynardville Limestone (Cmn). A geological profile, included in the Appendix (Figure 51), describes the average characteristics of the site subsurface with more detail. 


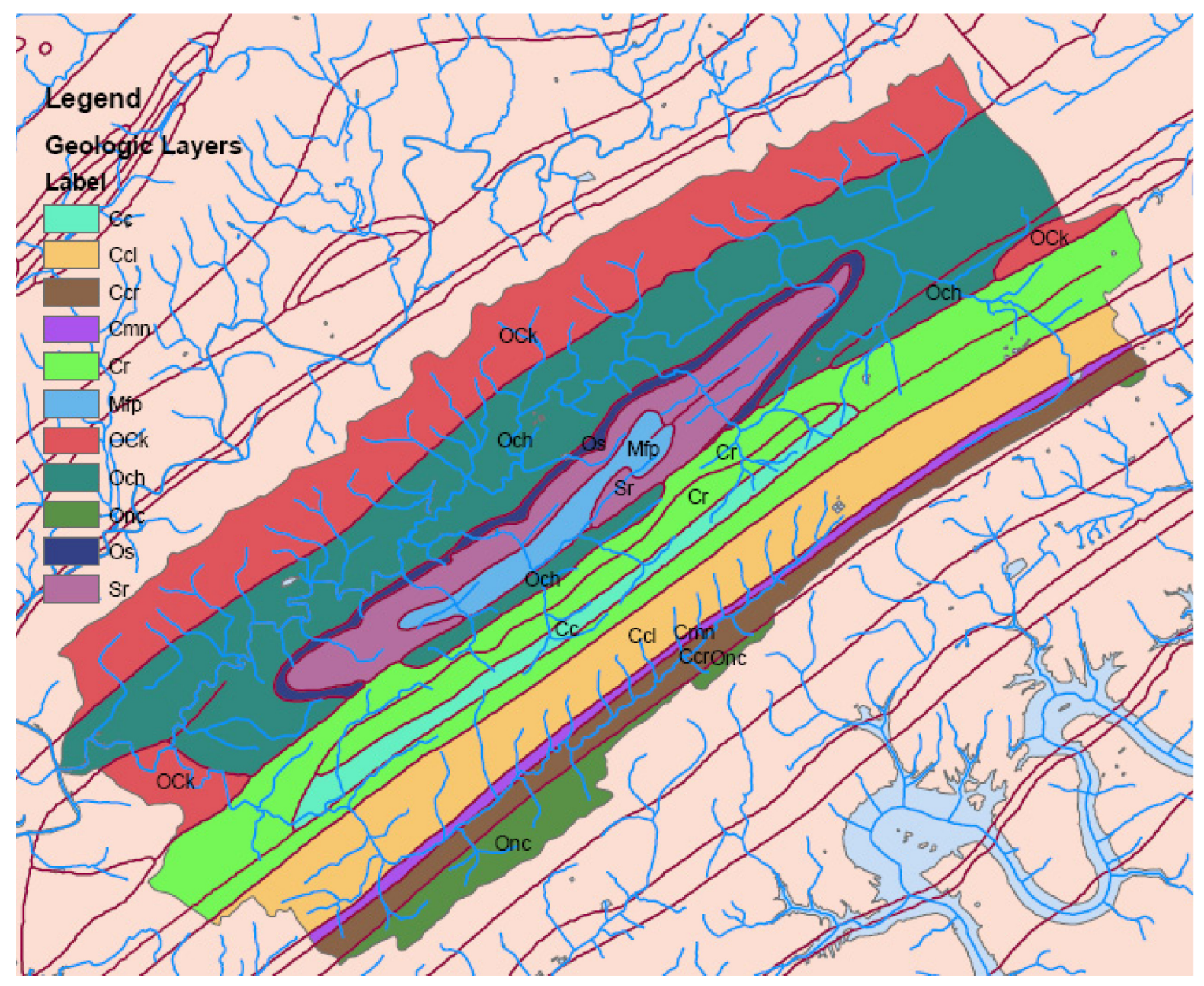

Figure 5 Geologic layers of EFPC

In ORR, two broad hydrologic units dominate the subsurface landscape: the Knox (OCk) aquifer in which flow is controlled by solution conduits, and the leaky confining units of ORR in which flow is dominated by fractures. Both groups are described by a stormflow zone, a vadose zone, a groundwater zone, and the confining unit (ORNL, 1992).

The groundwater flow on the ORR is primarily influenced by topography, surface cover, geologic structure, and lithology. ORR lies above the geologic formation known as the Chickamauga Group, which is leaky confining unit with flow limiting strata and relatively low hydraulic conductivity (ATSDR, 2006). 
Shallow groundwater from the Y-12 Complex drains via gravity to the upper reaches of EFPC. Any contamination from the area first reaches the water table or runoff via overland flow where it is then captured in storm drains or catch basins. These structures are situated above the water table and are therefore considered perennially losing. The contamination then drains to the groundwater. Water movement in the lower shales and limestones is notably small, forcing contaminant transport in the faster moving water table. As the water reaches the lower valley, Karst-like conduits can rapidly transport contaminants. Some groundwater is pumped and treated before being released to the creek.

A shallow subsurface stormflow zone (1-2 m thick), which approximately translates to the root zone, is underlain by an unsaturated zone of variable thickness (1-15 $\mathrm{m})$ which separates the stormflow zone and the water table. Approximately $95 \%$ of all groundwater flow in the ORR occurs in the shallow saturated zone (i.e., the upper 15-30 m) and ends up either as diffuse discharge to surface waters or discharge via springs and seeps (ORNL, 2006).

EFPC watershed contains two small rivers $(>12,500 \mathrm{~km}$ long) and several tributaries which are illustrated in Figure 6. Stream data was obtained from USGS. The tributaries with nationally recognized names are described in detail below:

- East Fork Poplar Creek runs primarily in a NE to SW direction and is about 24,610 meters long. The creek bottom begins at a depth of about $287 \mathrm{~m}$ above sea level and ends at about $226 \mathrm{~m}$ near the river's hydrologic boundary, for a general slope of about $0.23 \%$ or 0.13 degrees. Stream valley widths, along East Fork Poplar Creek, range from about 60 to 300 meters. EFPC receives discharge from 
four major streams (Bear Creek, Gum Hollow Branch, Mill Branch, and Pin Hook Branch) and about 30 unnamed tributaries. In total, East Fork Poplar Creek receives discharge from about 107 kilometers of streams.

- Bear Creek is the second largest stream in the watershed at about 12,700 meters long. This stream runs mostly parallel to East Fork Poplar Creek. The creek bottom begins at a depth of about $309 \mathrm{~m}$ above sea level and ends at about $227 \mathrm{~m}$ where the river discharges to EFPC, for a general slope of about $0.62 \%$ or $0.354^{\circ}$. Stream valley widths, along Bear Creek, range from about 50 to 300 meters. Bear Creek receives discharge from about 28 unnamed tributaries for a total of about 24 kilometers of streams.

- Gum Hollow Branch is the third largest stream in the watershed at about 4,130 meters long. This stream receives discharge from about 8 unnamed tributaries. In total, Gum Hollow Branch receives discharge from about 6.7 kilometers of streams before discharging to EFPC.

- Mill Branch is about 3,270 meters long and receives discharge from about 5 unnamed tributaries. In total, Mill Branch receives discharge from about 7.2 kilometers of streams before discharging to EFPC.

- Pin Hook Branch is about 2,040 meters long and receives discharge from about 4 unnamed tributaries. In total, Pin Hook Branch receives discharge from about 1.8 kilometers of streams before discharging to EFPC. 


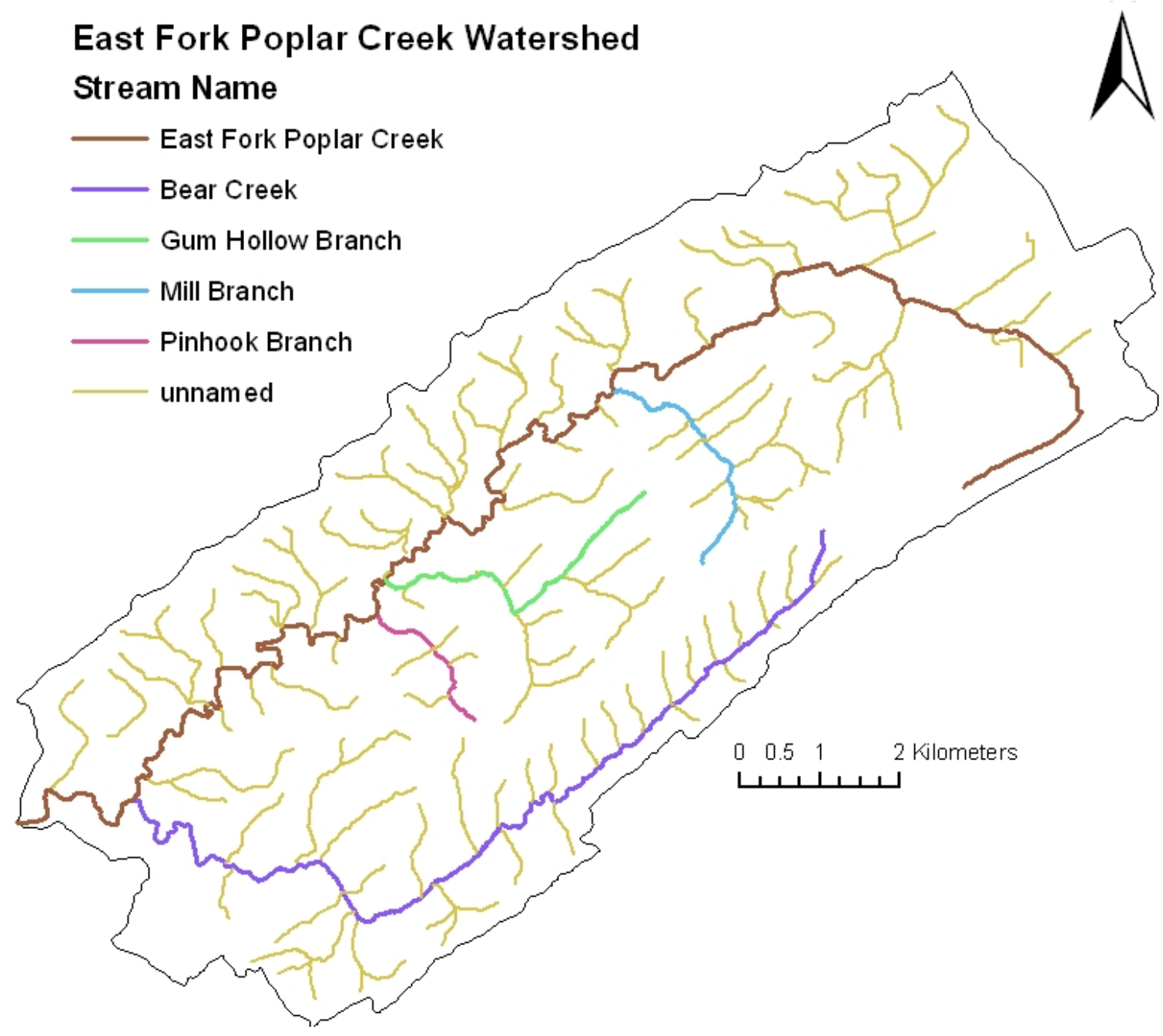

Figure 6 Primary streams within EFPC watershed

The 2001 National Land Cover Dataset (NLCD) provides 21 classifications of land uses for the US, as shown in Table 1. The Dataset is gathered over large areas using Landsat imagery and high-altitude, infrared photography.

Vegetation plays an important role on the hydrology of the watershed by affecting the speed of overland flow due to friction (Manning's number) and by changing the path of water by plant uptake and transpiration (evapotranspiration), The watershed is over $55 \%$ forest land, with about $87 \%$ of the forested areas considered deciduous forests (typical 
hardwoods such as oaks, maples, hickories, etc.). About one third of EFPC watershed is used for agricultural purposes. The agricultural area is somewhat evenly divided between cropland and pasture (i.e. wheat fields and grazing pastures), orchards and groves (fruit and nut crops), and confined feeding operations (livestock pens).

Table 1 NLCD 2001 Land use classification and Manning's number

\begin{tabular}{|c|c|c|c|c|c|}
\hline $\begin{array}{l}\text { Classification } \\
\text { (NLCD2001) }\end{array}$ & $\begin{array}{c}\text { NLCD } \\
2001 \\
\text { Code } \\
\end{array}$ & $\begin{array}{c}\text { Anderson } \\
\text { Level } 1 \\
\text { Code } \\
\end{array}$ & $\operatorname{Area}\left(m^{2}\right)$ & $\%$ /Area & $\begin{array}{l}\text { Manning's } \\
\text { M number }\end{array}$ \\
\hline Open Water & 11 & 1 & 11410200 & $4 \%$ & 50 \\
\hline $\begin{array}{l}\text { Developed, Open } \\
\text { Space }\end{array}$ & 21 & 2 & 28142100 & $10 \%$ & 50 \\
\hline $\begin{array}{l}\text { Developed, Low } \\
\text { Intensity }\end{array}$ & 22 & 2 & 23315400 & $8 \%$ & 20 \\
\hline $\begin{array}{l}\text { Developed, Medium } \\
\text { Intensity }\end{array}$ & 23 & 2 & 11262600 & $4 \%$ & 10 \\
\hline $\begin{array}{l}\text { Developed, High } \\
\text { Intensity }\end{array}$ & 24 & 2 & 5488200 & $2 \%$ & 7 \\
\hline $\begin{array}{l}\text { Barren Land, Rock, } \\
\text { Sand, Clay }\end{array}$ & 31 & 3 & 1053900 & $0 \%$ & 11 \\
\hline Deciduous Forest & 41 & 4 & 124686000 & $45 \%$ & 10 \\
\hline Evergreen Forest & 42 & 4 & 15189300 & $5 \%$ & 9 \\
\hline Mixed Forest & 43 & 4 & 9044100 & $3 \%$ & 10 \\
\hline Shrub, Scrub & 52 & 5 & 300600 & $0 \%$ & 20 \\
\hline $\begin{array}{l}\text { Grassland, } \\
\text { Herbaceous }\end{array}$ & 71 & 5 & 4901400 & $2 \%$ & 29 \\
\hline Pasture, Hay & 81 & 6 & 34282800 & $12 \%$ & 30 \\
\hline Cultivated Crops & 82 & 6 & 799200 & $0 \%$ & 27 \\
\hline Woody Wetlands & 90 & 7 & 9374400 & $3 \%$ & 10 \\
\hline $\begin{array}{c}\text { Emergent } \\
\text { Herbaceous Wetlands }\end{array}$ & 95 & 7 & 5400 & $0 \%$ & 22 \\
\hline
\end{tabular}




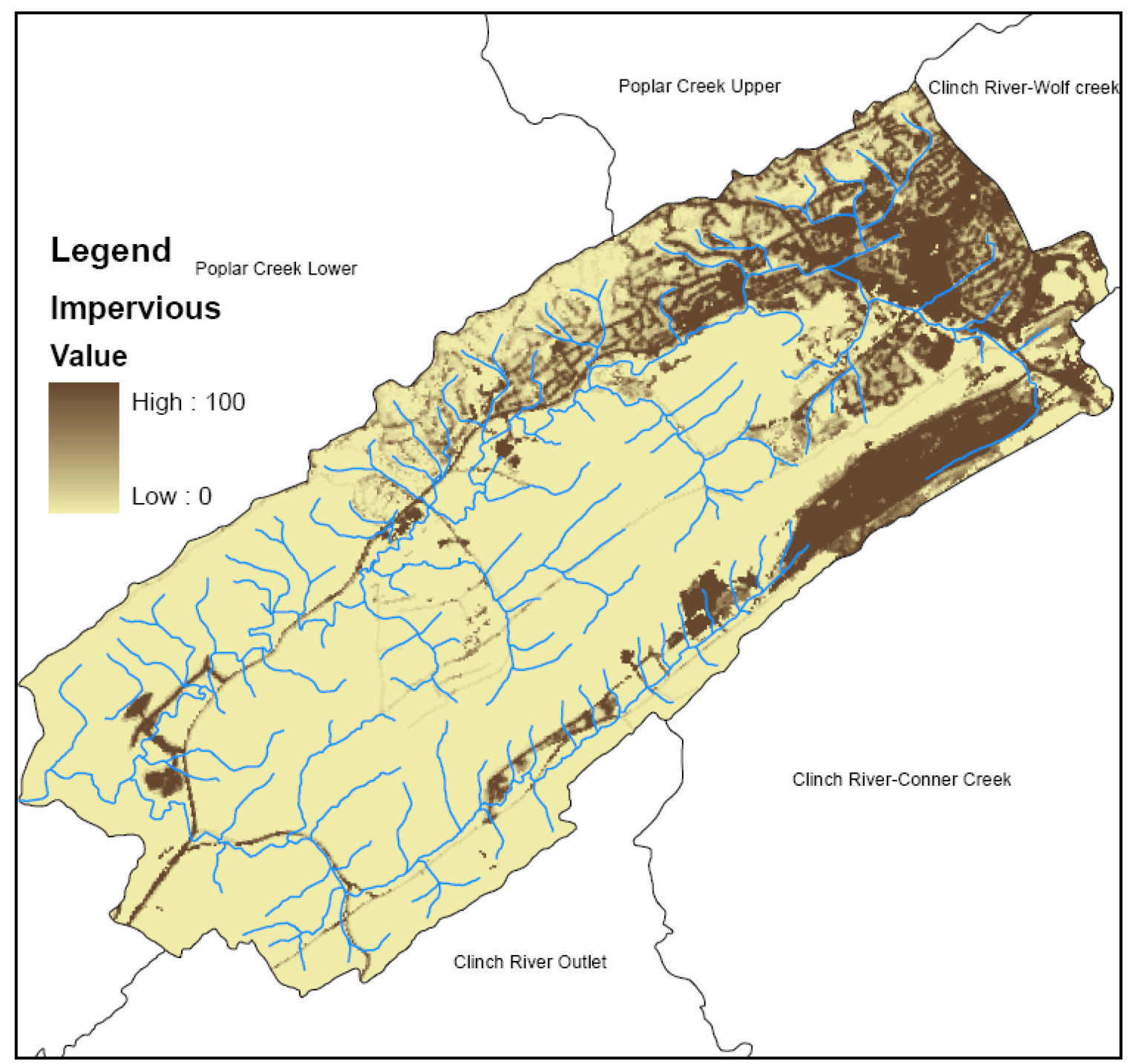

Figure 7 Percent imperviousness for EFPC watershed

The 2001 NLCD Impervious Surface raster was analyzed using GIS. About 9.3\% of the total watershed area has an imperviousness of $50 \%$ or greater. The impervious percentage mainly comes from residential areas, cities, and highways. About $4.4 \%$ of the total area has an imperviousness of $75 \%$ or greater, this includes most of the Y-12 National Security Complex and the commercial areas in the City of Oak Ridge. These areas of high imperviousness may tend to transport contaminants more rapidly due to increased rate of overland flow and infrastructure facilitation. Figure 7 maps the 
developed areas of EFPC watershed, including roads and buildings, by illustrating the percent of impervious cover. Over $82.3 \%$ of the total area of EFPC watershed has an imperviousness of $25 \%$ or less. This indicates that, overall, the watershed is mostly undeveloped or agricultural land. This conclusion is compatible with the land use data, which establishes that about $88.6 \%$ of the watershed is forested or agricultural.

\section{DEVELOPMENT OF THE FLOW MODEL}

The modeling system consists of coupled MIKE SHE (a 3-dimensional saturated and unsaturated groundwater flow, 2-dimensional overland flow model) and MIKE 11 (1dimensional river flow model). MIKE SHE is a deterministic, physically based \& fully distributed hydrological modeling system (Abbott and Refsgaard, 1996). It consists of the Water Movement and Water Quality modules. The hydrological processes are described mostly by physical laws (laws of conservation of mass, momentum and energy).

The one-dimensional and two-dimensional diffusive wave Saint Venant equations describe channel and overland flow, respectively. The Kristensen and Jensen methods are used for evapotranspiration, the one-dimensional Richards's equation for unsaturated zone flow, and a three-dimensional Boussinesq equation for saturated zone flow. These partial differential equations are solved by finite difference methods, while other methods (interception, evapotranspiration and snowmelt) in the model are empirical equations obtained from independent experimental research (DHI, 2006).

MIKE 11 is a one-dimensional modeling tool for the detailed analysis, design, management and operation of both simple and complex river and channel systems. The MIKE 11 Hydrodynamic (HD) module solves the vertically integrated equations for the conservation of continuity and momentum, i.e. the Saint Venant equations (DHI, 2008). 
The HD module is the nucleus of the MIKE 11 modeling system and forms the basis for most modules including Flood Forecasting, Advection-Dispersion, Water Quality and Non-cohesive sediment transport modules. The basic steps for modeling the surface and subsurface hydrology include:

a. Modeling of the subsurface saturated flow using MIKE SHE.

b. Incorporation of evapotranspiration and unsaturated flow into MIKE SHE.

c. Modeling the river flow using MIKE 11.

d. Adding the advection and dispersion component into MIKE SHE and MIKE 11.

e. Coupling MIKE SHE and MIKE 11 to create an integrated hydrological model.

f. Uncertainty analysis of hydrologic and advection-dispersion parameters, model calibration and verification.

g. Simulation of the mapped mercury contamination due to historical spills at the Y12 Complex.

h. Simulation and analysis of various remediation strategies.

MIKE SHE and MIKE 11 were coupled by defining branches (reaches) where MIKE 11 HD interacts with MIKE SHE; which, for this model, was every stream within the domain. The list of streams and the coupling with MIKE SHE is shown in the appendix in Table 15 on page 87 . The hydrologic components of MIKE SHE are directly coupled to DHI's river hydraulic program MIKE 11. The MIKE SHE/MIKE 11 coupling enables:

- One-dimensional simulation of river flows and water levels using the fully dynamic Saint Venant equations.

- Simulation of a wide range of hydraulic control structures, such as weirs, gates and culverts. 
- Area-inundation modeling, using a simple flood-mapping procedure that is based on simulated river water levels and a digital terrain model.

- Dynamic overland flooding flow to and from the MIKE 11 river network.

- Full, dynamic coupling of surface and sub-surface flow processes in MIKE 11 and MIKE SHE.

To simulate flooding on the flood plain the option for Direct Overbank Spilling to and from MIKE 11 was used. In this case the MIKE 11 cross-sections are normally restricted to the main channel. The flood plain is defined as part of the MIKE SHE topography. Since, the bank elevation is used to define when a cell floods, a special emphasis was placed on ensuring that that the cross-sections are consistent with the topography, especially in the areas where flooding was simulated. The table in the simulation log file was used to locate any inconsistencies and the elevation data of the cross section was revised. The availability of fine grid and detailed DEM has reduced the inconsistencies and the amount of interpolation and averaging when creating the model topography. Subsequently the MIKE SHE and MIKE 11 models were modified to work together properly by removing the specified groundwater table in MIKE 11 and adjusting the SZ drainage elevations used for testing purposes.

The exchange between the river and groundwater was simulated by modeling the river in full contact with the aquifer material, due lack of low permeable lining of the river bed which is typical for mountain areas. In this case, the only head loss between the river and the grid node is that created by the flow from the grid node to the river itself. This is typical of gaining streams, or streams that are fast moving. 


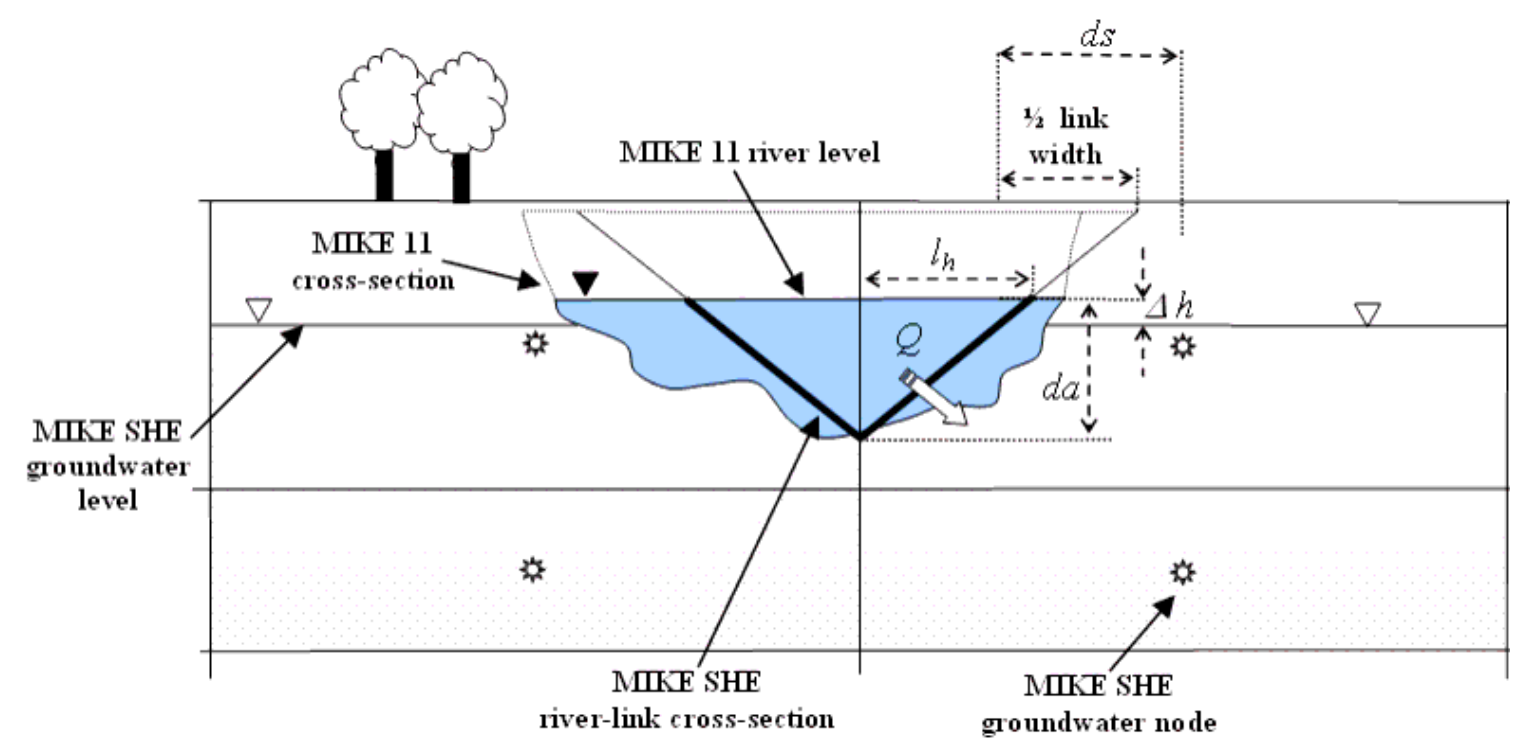

Figure 8 MIKE SHE/MIKE 11 river link cross-section (DHI, 2008)

The typical MIKE SHE river cross section in Figure 8 is compared to an equivalent MIKE $11 \mathrm{HD}$ cross section. In this case, the conductance, $\mathrm{C}$, between the grid node and the river link is given by:

$$
C=\frac{K \cdot d a \cdot d x}{d s}
$$

where $K$ is the horizontal hydraulic conductivity in the grid cell, $d a$ is the vertical surface available for exchange flow, $d x$ is the grid size used in the saturated zone component, and $d s$ is the average flow length. The average flow length, $d s$, is the distance from the grid node to the middle of the river bank in the triangular, river-link crosssection. $d s$ is limited to between $1 / 2$ and $1 / 4$ of a cell width, since the maximum river-link width is one cell width (half cell width per side).

The MIKE $11 \mathrm{HD}$ model accounts for the water table level for the watershed using three methods for calculating $d a$ :

- If the water table is higher than the river water level, $d a$ is the saturated aquifer 
thickness above the bottom of the river bed. Note, however, that $d a$ is not limited by the bank elevation of the river cross-section, which means that if the water table in the cell is above the bank of the river, $d a$ accounts for overland seepage above the bank of the river.

- If the water table is below the river level, then $d a$ is the depth of water in the river.

- If the river cross-section crosses multiple model layers, then $d a$ (and therefore $\mathrm{C}$ ) is limited by the available saturated thickness in each layer. The exchange with each layer is calculated independently, based on the $d a$ calculated for each layer. This makes the total exchange independent of the number of layers the river intersects.

- This formulation for $d a$ assumes that the river-aquifer exchange is primarily via the river banks, which is consistent with the limitation that there is no unsaturated flow calculated beneath the river.

The MIKE 11 HD hydraulic model uses the precise cross-sections, as defined in the MIKE 11 .xns11 (cross-section) file, for calculating the river water levels and the river volumes. However, the exchange of water between MIKE 11 and MIKE SHE is calculated based the river-link cross-section. The river-link uses is a simplified, triangular cross-section interpolated (distance weighted) from the two nearest MIKE 11 crosssections. The top width is equal to the distance between the cross-section's left and right bank markers. The elevation of the bottom of the triangle equals the lowest depth of the MIKE 11 cross-section (the elevation of Marker 2 in the cross-section). The left and right bank elevations in MIKE 11 (cross-section markers 1 and 3 in MIKE 11) are used to define the left and right bank elevations of the river link. 


\subsection{Model Domain}

The domain of the project is defined as the entire EFPC watershed as delineated by USGS. It is formally recognized by its assigned 12-digit Hydrologic Unit Code, HUC 060102070302. EFPC watershed has a large drainage area of about 29.7 square miles

$\left(\mathrm{mi}^{2}\right)$, more domain characteristics are shown in Table 2. This domain was chosen to illustrate large-scale fluctuations in the mercury cycling and transport.

Table 2 Domain characteristic

\begin{tabular}{|cc|}
\hline Parameter & Value \\
\hline Total drainage area, in square miles & 28.8 \\
\hline Area that contributes flow to a point on a stream, in square miles & 28.8 \\
\hline Tennessee climate factor, 2-year interval & 2.249 \\
\hline Streamflow-recession index, in days per log cycle of decrease in discharge & 67 \\
\hline Stream slope 10 and 85 method in feet per mile & 11.3 \\
\hline Percent area underlain by soil permeability of at least 2 in $/ \mathrm{hr}$ & 39 \\
\hline Soil Permeability $-\mathrm{in} / \mathrm{hr}$ & 2.43 \\
\hline
\end{tabular}

The domain was created by utilizing a GIS shapefile of the EFPC watershed (derived

from the USGS National Hydrography Dataset) (USGS, 2007). Grid cells inside the model domain are assigned a value of 1 and grid cells on the model boundary are assign a value of 2 as required. This distinction between interior grid cells and boundary cells is to facilitate the definition of boundary conditions. For example, drainage flow can be routed to external boundaries but not to internal boundaries.

\subsection{Topography}

The model input for topography was generated by adding the $2 \mathrm{~m} \mathrm{DEM}$ in text format to MIKE and was then exported as a .dfs2 file, which is a native MIKE SHE file format. The .dfs 2 file was then used to replace the Contour shapefile in the model. Figure 9 shows the topography used for the EFPC region, the watershed is outlined in red. 


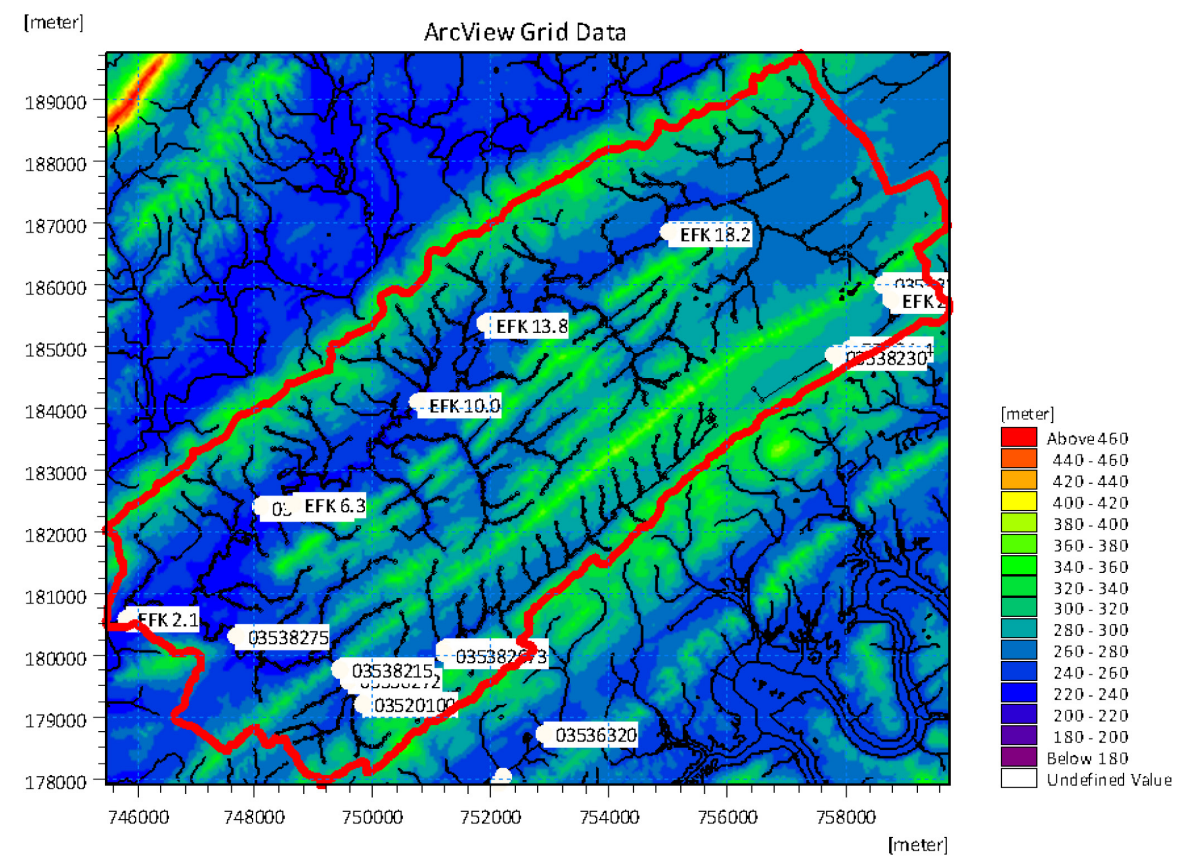

Figure 9 Topography of the study area represented in the software

\subsection{Climate Data}

The climate data was acquired from the National Oceanic and Atmospheric Administration (NOAA) climatological dataset complied for the state of Tennessee. Precipitation data is represented as water equivalent totals and includes liquid and melted frozen precipitation. For the purposes of this project it is unnecessary to include separate snow melt data, as it is summarized in the precipitation data.

\subsubsection{Precipitation}

For use in MIKE SHE, the Precipitation Rate can be specified as a rate (e.g. mm/hr) or as an amount (e.g. mm). If an amount is used, MIKE SHE automatically converts this to a rate during the simulation. If a rate is used, then the EUM Data Units must be Precipitation and the time series must be Mean Step Accumulated. If an amount is used, the EUM Data Units must be Rainfall and the time series must be Step Accumulated. 


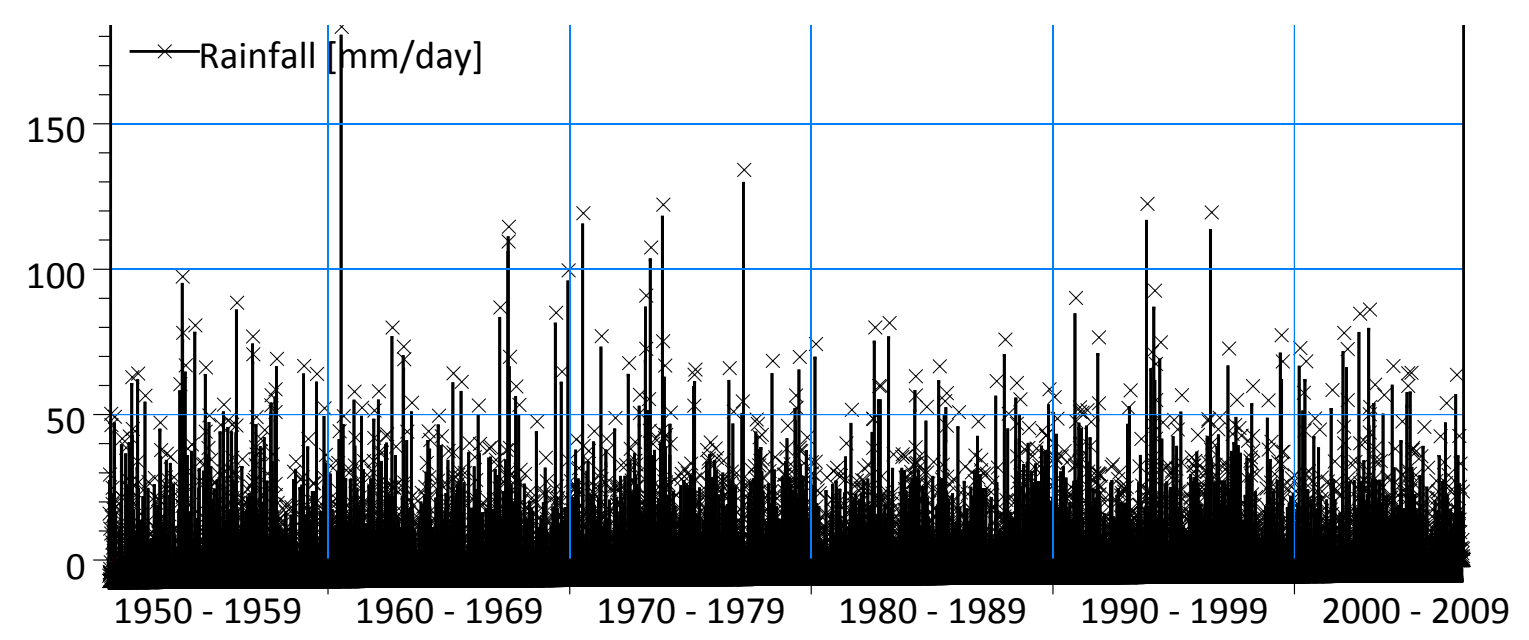

Figure 10 Precipitation for $1 / 1 / 1950$ to $12 / 31 / 2008$

For the model, the Precipitation rate time series used a Step Accumulated Rainfall for the Rainfall data in millimeters for the duration of one day. Figure 10 shows the input rainfall data for approximately 50 years (01/01/1950-12/31/2008); however, MIKE SHE will only use the data within the user-specified Simulation Period.

Precipitation is a critical variable for the model because it determines the surface water flows in the watershed and the dynamics of the groundwater table. For each of the simulation runs, a preliminary simulation was executed starting three months earlier than the specified time period and the results were saved and used for hot start. The purpose of this preliminary simulation was to ensure that the system is fully developed.

\subsubsection{Evapotranspiration}

The calculation of evapotranspiration (ET) uses meteorological and vegetative data to predict the total ET and net rainfall due to:

- Interception of rainfall by the canopy,

- Drainage from the canopy to the soil surface,

- Evaporation from the canopy surface, 
- Evaporation from the soil surface, and

- Uptake of water by plant roots and its transpiration, based on soil moisture in the unsaturated root zone.

MIKE SHE models ET using two distinct methods. The primary ET model is utilizes formulas derived from the work of Kristensen and Jensen (1975). In this model, the actual ET and the actual soil moisture status in the root zone is calculated from the potential evaporation rate, along with maximum root depth and leaf area index for the plants.

The 2-Layer Water Balance Method is an alternative to the more complex unsaturated flow process coupled to the Kristensen and Jensen module for describing ET. The 2Layer Water Balance Method is based on a formulation presented in Yan and Smith (1994), the main purpose of which is to calculate actual ET and the amount of water that recharges the saturated zone. The module is particularly useful for areas with a shallow ground water table, such as swamps or wetlands areas, where the actual ET rate is close to the reference rate. The 2-Layer Water Balance Method includes the processes of interception, ponding, and ET, while considering the entire unsaturated zone to consist of two 'layers' representing average conditions in the unsaturated zone. The vegetation is described in terms of leaf area index (LAI) and root depth (RD).

At this point in the model setup, only a reference ET was needed for the Climate section. The reference ET is the rate of ET from a reference surface with an unlimited amount of water. This value is independent of everything but climate and can be calculated from weather data. Tennessee has an annual ET of about 28.7 inches, therefore a constant reference ET value of $2.01168 \mathrm{~mm} /$ day was used. The reference ET was then 
adjusted according to the vegetation data (leaf area index and root depth) found in the following section (see Land use).

\subsection{Land use}

In MIKE SHE, the ET process proceeds as follows: a portion of rainfall is intercepted by the canopy and evaporates, the remainder reaches the soil and adds to runoff or percolates into the upper soil layer, part of the infiltrating water is either transpired by plant roots or evaporated, and the remaining water recharges the groundwater. The various sections where plants intercept the path of water are spatially distributed by the LAI and RD parameters of the vegetation maps.

The landuse was imported as vegetation maps and assigned Leaf Area Index (LAI) constant values and Root Depth (RD) constant values obtained from USGS. Table 3 shows the LAI and RD values assigned for each feature. These parameters are used to spatially adjust the reference ET described in the Climate section.

Table 3 Vegetation data and Manning's number

\begin{tabular}{|c|c|c|c|c|}
\hline Grid Code & Class Name & LAI & RD (mm) & Manning's M \\
\hline 11 & Open Water & 0 & 0 & 50 \\
\hline 21 & Developed, Open Space & 3 & 2000 & 50 \\
\hline 22 & Developed, Low Intensity & 2.5 & 2000 & 20 \\
\hline 23 & Developed, Medium Intensity & 2 & 2000 & 10 \\
\hline 24 & Developed, High Intensity & 1.5 & 2000 & 7 \\
\hline 31 & Barren Land, Rock, Sand, Clay & 1.31 & 4000 & 11 \\
\hline 41 & Deciduous Forest & 5.5 & 2000 & 10 \\
\hline 42 & Evergreen Forest & 5.5 & 1800 & 9 \\
\hline 43 & Mixed Forest & 5.5 & 2400 & 10 \\
\hline 52 & Shrub, Scrub & 2.08 & 2500 & 20 \\
\hline 71 & Grassland, Herbaceous & 1.71 & 1500 & 29 \\
\hline 81 & Pasture, Hay & 1.71 & 1500 & 30 \\
\hline 82 & Cultivated Crops & 3.62 & 1500 & 27 \\
\hline 90 & Woody Wetlands & 6.34 & 2000 & 10 \\
\hline 95 & Emergent Herbaceous Wetlands & 6.34 & 2400 & 22 \\
\hline
\end{tabular}




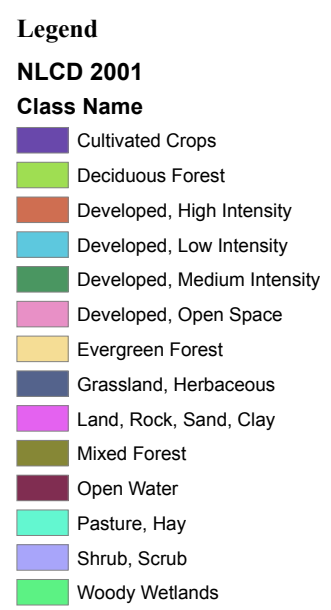

Figure 11 Discretization of landuse data used for the hydrological model

The 2001 National Land Cover Dataset (NLCD) was used in the model to support data that requires landuse information to be spacially adjusted. Figure 11 illustrates the NCLD data that was used for the model development.

\subsection{Saturated Zone}

The vertical discretization of the Saturated Zone includes 2 layers, the lowest level of the upper layer 30 meters below the surface and the lowest level of the lower layer is 100 meters below the ground surface elevation. Horizontal and Vertical Hydraulic Conductivity are functions of the soil texture and are related to the ease with which water can flow through the soil. MIKE SHE assumes that the horizontal conductivity is 
isotropic in the $\mathrm{x}$ and $\mathrm{y}$ directions. For initial approximation of the flow, the horizontal hydraulic conductivity was assumed 10 times higher than the vertical hydraulic conductivity. A horizontal hydraulic conductivity of $1.0 \mathrm{e}-04 \mathrm{~m} / \mathrm{s}$ and a vertical hydraulic conductivity of $1.0 \mathrm{e}-05 \mathrm{~m} / \mathrm{s}$ were used.

In unconfined aquifer, Specific Yield is defined as the volume of water released per unit surface area of aquifer per unit decline in head. It is a dimensionless characteristic that is used only in transient simulations in cells that contain the water table. (See MIKE SHE manual Volume 2 pg 114). Specific Storage is similar, but is defined as the volume of water released per volume of aquifer per unit decline in head and has units of $\mathrm{L}^{-1}$. A Specific Yield of 0.2 and a Specific Storage of $3.0 \times 10^{-5}$ (Engineering Study Work Plan, Appendix D, Table D.1) were used.

MIKE SHE requires a reference system for linking the drainage to a recipient node or cell. The recipient can be a MIKE 11 river node, another SZ grid cell, or a model boundary. Drainage routed downhill based on adjacent drain levels was the option used for all simulations. Whenever drain flow is produced during a simulation, the computed drain flow is routed to the recipient point using a linear reservoir routing technique. The reference system is created automatically by the pre-processor using the slope of the drains calculated from the drainage levels in each cell. Thus, the pre-processor calculates the drainage source-recipient reference system by:

- looking at each cell in turn,

- look for the neighboring cell with the lowest drain level

- if this cell is an outer boundary cell or contains a river link, the search stops.

If the cell does not contain a boundary or river link, then the next search is repeated 
until either a local minimum is found or a boundary cell or river link is located. The result of the above search for each cell is used to build the source recipient reference system. If local depressions in the drainage levels exist, the SZ nodes in these depressions may become the recipients for a number of drain flow producing nodes. This often results in the creation of a small lake at such local depressions. If overland flow is simulated, then the drainage water will become part of the local overland flow system. The drainage level was assumed $-1.0 \mathrm{~m}$ relative to the ground, the drainage time constant was assumed $1.0 \times 10^{-6} \mathrm{sec}^{-1}$, after performing calibration studies and uncertainty analysis.

\subsection{Unsaturated Flow}

MIKE SHE was applied to a two-layer surficial aquifer profile, an unsaturated layer which incorporates an approximated $1 \mathrm{~m}$ root zone and a $5 \mathrm{~m}$ underlying soil matrix, and the upper shallow saturated zone with a groundwater depth of 17 meters.

Each soil textural type has certain hydrological properties which are essential for the solute transport theory. The soil literature contains numerous assessments of soil water characteristics and hydraulic conductivity values, which are often not easy to determine experimentally. The van Genuchten model (1976) is a simplified widely used approach for prediction of soil water content as a function of pressure head. This model is represented by the following algorithm:

$$
\theta=\theta r+\frac{(\theta s-\theta r)}{\left[1+(\alpha h)^{N}\right]^{M}}
$$

Where: $\theta$-water content; $\theta r$-residual water content; $\theta s$-total saturated water content; $\alpha$ -

empirical constant, $\mathrm{cm}^{-1}$; N-empirical constant; M-empirical constant; $h$-capillary head, $\mathrm{cm}$. The correlation between $\mathrm{N}$ and $\mathrm{M}$ is as follows: 


$$
M=1-1 / N
$$

Hydraulic conductivity is expressed by:

$$
\frac{K(\theta)}{K s}=\left\{\frac{\theta-\theta r}{\theta s-\theta r}\right\}^{1 / 2}\left\{1-\left[1-\left(\frac{\theta-\theta r}{\theta s-\theta r}\right)^{1 / M}\right]^{M}\right\}^{2}
$$

Where $\mathrm{K}(\theta)$ is the hydraulic conductivity for a given water content $\left(\mathrm{cm} \mathrm{h}^{-1}\right)$ and $\mathrm{Ks}$ is the saturated hydraulic conductivity $\left(\mathrm{cm} \mathrm{h}^{-1}\right)$. Parameters for equation (1) were obtained from the Carsel and Parrish database (1988). All acquired values of saturated hydraulic conductivities (Ks) and van Genuchten water retention parameters $(\theta r, a, \mathrm{~N})$ for each of the soil texture types identified in the study area are presented in Table 4 .

The identified soil groups were further categorized into the five textural types such as loam, silt loam, clay loam, silty clay loam, and clay (Hatcher et al, 1992) presented in Table 4.

\begin{tabular}{|c|c|c|c|c|c|c|}
\hline Texture & Loam & $\begin{array}{c}\text { Silt } \\
\text { Loam }\end{array}$ & $\begin{array}{l}\text { Clay } \\
\text { Loam }\end{array}$ & $\begin{array}{l}\text { Silty } \\
\text { Clay } \\
\text { Loam }\end{array}$ & Clay & No data \\
\hline $\begin{array}{l}\text { Residual Water } \\
\text { Content, } \theta \mathrm{r} \\
\end{array}$ & 0.078 & 0.067 & 0.095 & 0.089 & 0.068 & \\
\hline $\begin{array}{c}\text { Saturated Water } \\
\text { Content, } \theta \mathrm{s}\end{array}$ & 0.43 & 0.45 & 0.41 & 0.43 & 0.38 & \\
\hline $\begin{array}{c}\text { Water Retention } \\
\text { Parameter, a, } \mathrm{cm}^{-1}\end{array}$ & 0.036 & 0.02 & 0.019 & 0.01 & 0.008 & \\
\hline $\begin{array}{c}\text { Water Retention } \\
\text { Model Parameter, } \\
\mathrm{N} \\
\end{array}$ & 1.56 & 1.41 & 1.31 & 1.23 & 1.09 & \\
\hline $\begin{array}{c}\text { Hydraulic } \\
\text { Conductivity, Ks, } \\
\mathrm{cm} \mathrm{hr}^{-1}\end{array}$ & 1.04 & 0.45 & 0.26 & 0.07 & 0.2 & \\
\hline $\begin{array}{c}\text { Area near WOC, } \\
\mathrm{m}^{2}\end{array}$ & 276,990 & 909,296 & 377,262 & 203,360 & 602,150 & 165,583 \\
\hline $\begin{array}{c}\% \text { Total Soil Area } \\
\text { near WOC }\end{array}$ & 10.9 & 35.9 & 14.9 & 8 & 23.8 & 6.5 \\
\hline
\end{tabular}

Table 4 Van Genuchten's soil hydraulic parameters 


\subsection{Rivers}

The morphological characteristics of a river channel and floodplain are important parameters needed to create an accurate hydraulic simulation. These characteristics include channel width and depth, as well as floodplain cross-section area. Geometry data was developed by utilizing a high resolution DEM with an approximate resolution of two meters. The first step was to identify cross sections locations that would accurately depict the morphological characteristics of the channels in the EFPC watershed.

\subsubsection{River Network and cross sections}

The major streams in EFPC were identified using a shape file from USGS. Streams identified in the shapefile include up to 115 tributaries. Figure 12 shows the river network file in MIKE 11.

After inspecting the profile of each tributary and determining the locations of slope changes, a significant number of cross sections were gathered for each stream to accurately reproduce the river profile. Using the 3-D Analyst extension in ArcGIS, profile graphs were created by interpolating lines along the established cross section locations. These lines depicted a horizontal profile of the channel when intersected by the DEM. Cross section lines were drawn perpendicular to the direction of flow by visualizing the topographic features. A key step involved drawing all the lines from left

bank to right bank when facing upstream. Cross sections were wide enough to cover the entire floodplain. Cross sections of approximately 100 meters wide were gathered. 


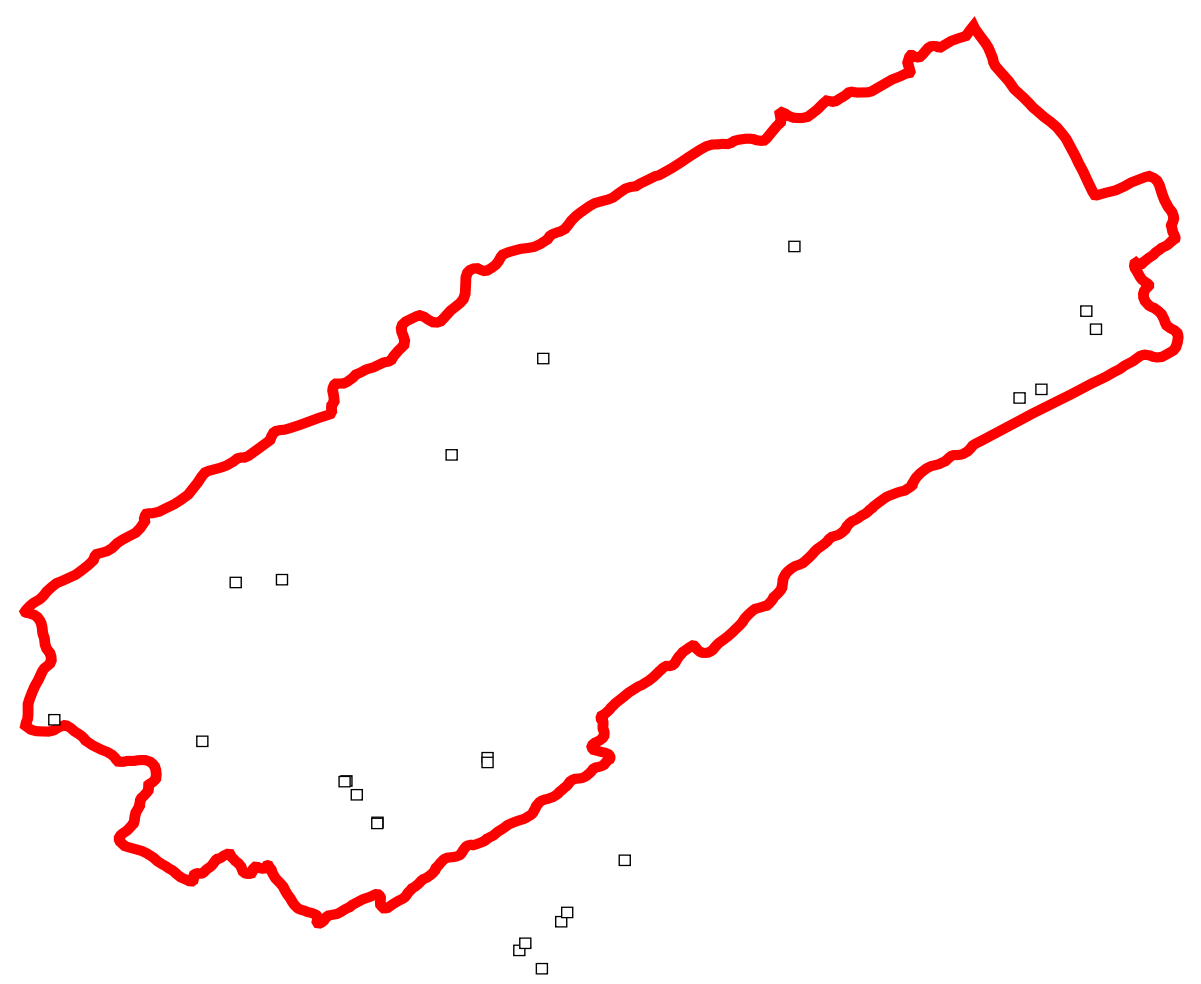

Figure 12 River Network and domain with cross section locations, boundaries and intersections

Although the discharge on the tributaries is minimal, years of scouring have formed clearly defined channels in the area. Once a cross section profile was established, the 3-D Analyst tool in ArcGIS allowed exporting the data as elevation points. A separate spreadsheet was created for each cross section containing between 35 to 50 points. By adding the cross sections locations GIS shapefile to the MIKE 11 network editor, cross sections were established precisely at the point where they were drawn on GIS. The data for the cross section coordinates were further transferred in the river cross sectional editor of MIKE 11. A reasonably high number of river cross-sections were included to ensure that the river elevations are consistent with the surface topographic features in the MIKE SHE model. Many of the smaller reaches showed no significant channel bed in GIS, and 
were assigned generalized trapezoidal cross-sections which provided average conveyance for that reach. More than 800 cross sections were created and entered into the MIKE 11 model.

\subsubsection{Boundary Conditions}

An Open Boundary was specified assuming free upstream and downstream ends of the model domain. Some of the boundary conditions used in the river model are shown in Table 5. The remaining branches, listed in Table 15 in the Appendix, were listed as Open with a constant inflow of zero.

Table 5 Boundary conditions for select rivers

\begin{tabular}{|cccc|}
\hline River Name & Boundary Description & Boundary Type & Chainage \\
\hline East Fork Poplar Creek & Open & Q-h & 25485.2 \\
\hline East Fork Poplar Creek & Open & Point Source & 3120.175 \\
\hline East Fork Poplar Creek & Open & Inflow & 0 \\
\hline Bear Creek & Open & Inflow & 0 \\
\hline Mill Branch & Open & Inflow & 0 \\
\hline Gum Hollow Branch & Open & Inflow & 0 \\
\hline Pinhook Branch & Open & Inflow & 0 \\
\hline
\end{tabular}

An open boundary condition has the following valid Boundary Types:

- Inflow was specified when a time-varying or constant flow hydrograph condition (for the HD model) is required with or without a solute component (for the AD model)

- Q-h was specified when the relationship between the discharge and the water level (HD model) is known and used with or without a solute component (used in the AD model);

After establishing a MIKE 11 HD hydraulic model as a stand-alone model a series of performance tests were executed and a rough calibration using prescribed inflow and 
stage boundaries was conducted. After testing the MIKE 11 HD hydraulic model as a stand-alone model a MIKE SHE model was established that includes the overland flow component, the saturated zone and unsaturated zone components. SZ drainage boundaries were used to prevent excessive surface flows in low lying areas and the river flood plain.

\subsection{Overland Flow}

When the net rainfall rate exceeds the infiltration capacity of the soil, water is ponded on the ground surface. This water is available as surface runoff, to be routed downhill towards the river system. The exact route and quantity is determined by the topography and flow resistance, as well as the losses due to evaporation and infiltration along the flow path. If it is unnecessary to simulate overland flow, a Manning's M of 0 will disable overland flow.

The overland flow can be calculated using either a semi-distributed method or a finite difference method using the diffusive wave approximation. The finite difference method should be used when calculating detailed overland flow, while the semi-distributed, simplified method should be used for regional applications where detailed overland flow is not required.

The outer boundary condition for the overland flow solver is a specified head, based on the initial water depth in the outer nodes of the model domain. Thus, if the water depth inside the model domain is greater than the initial depth on the boundary, water will flow out of the model. If the water depth is less than the initial depth on the boundary, the boundary will act as a source of water. The domain of the model is a delineated watershed, which should indicate that all of the water that falls within the domain flows to the rivers and out toward Poplar Creek. For this reason all of the overland flow within 
the domain is treated as a source of water and the Initial Water Depth is set to zero to ensure flow in this direction and not out of the domain. Detention Storage is used to limit the amount of water that can flow over the ground surface. For the model, detention storage is set to zero.

When the net rainfall rate exceeds the infiltration capacity of the soil, water is ponded on the ground surface. This water is available as surface runoff, to be routed downhill towards the river system. The exact route and quantity is determined by the topography and flow resistance, as well as the losses due to evaporation and infiltration along the flow path. The water flow on the ground surface is calculated by MIKE SHE's Overland Flow Module, using the diffusive wave approximation of the Saint Venant equations, or using a semi-distributed approach based on the Manning's equation. USGS has described a procedure for estimating the roughness factor (Manning's number) for densely vegetated flood plains (USGS, 1989). The $\mathrm{n}$ value is determined from the values of the factors that affect the roughness of channels and flood plains. In densely vegetated flood plains, the major roughness is caused by trees, vines, and brush. The $\mathrm{n}$ value for this type of flood plain can be determined by measuring the vegetation density of the flood plain.

MIKE SHE assumes Manning's number equal to: 1/n (i.e., inverse of Manning n); Manning n units $=\mathrm{s} / \mathrm{m}^{1 / 3}$, in software, Manning M units $=\mathrm{m}^{1 / 3} / \mathrm{s}$. For a planar surface of infinite width with uniform rainfall; precipitation falls on the plane, builds on the surface in response to the surface roughness, and flows down the slope in the positive x-direction. Where $y$ is the local depth of water on the surface at any point along the surface and $\alpha$ is the slope:

$$
q=M \cdot y^{5 / 3} \sqrt{\alpha}
$$


Assumed values for Manning n (Chow, 1959 and U.S. EPA, 2004) range between 0.01-0.05 (i.e., range between concrete and vegetated area, heavily vegetated areas can have $\mathrm{n}$ as high as 0.20 ).

\subsection{Calibration of the Hydrological Model}

Model calibration was carried out to evaluate and refine parameter values by comparing simulated and observed values in an attempt to generate a model that is closely representative of reality within a certain level of accuracy. This process was intended to improve the predictive reliability of the model. The main steps used for model calibration include:

1. Identification of calibration parameters.

2. Sensitivity Analysis - to identify parameters to which model predictions are most sensitive.

3. Numerical optimization - to determine a set of optimal or best-fit parameters which can be used to evaluate the model's predictive capability for certain hydrological or meteorological processes.

Table 6 Model Calibration Parameters

\begin{tabular}{|c|c|}
\hline Model component & Calibration Parameters \\
\hline River discharges & $\begin{array}{r}\text { Watershed hydrology (Manning's number, drainage constant, } \\
\text { drainage level, hydraulic conductivities) }\end{array}$ \\
\hline Saturated zone & Hydraulic Conductivity \\
\hline Unsaturated zone & Saturated hydraulic conductivity \\
\hline Drainage system & Drainage Constant \\
\hline Drainage system & Drainage Level \\
\hline Evapotranspiration & Crop coefficient \\
\hline Unsaturated zone & Saturated hydraulic conductivity \\
\hline
\end{tabular}


Table 6 lists some of the calibration parameters used in the development of the model. Variation of the selected calibration parameters in the range of 2 to $50 \%$ required several simulations to be carried out. The results obtained from these simulations provide the deviations observed between the simulated and the observed values and aid in determination of the optimal parameter values to be used for calibrating the model (Roelant et al., 2009).

The "stormflow zone", also known as the vadose zone or the shallow aquifer, is the upper layer in EFPC watershed with a hydraulic conductivity of $1 \mathrm{e}-04 \mathrm{~m} / \mathrm{s}$. The stormflow zone is the pathway for transporting and retention of contaminants from the subsurface sources to the local streams, which occurs through a 1-2 m thick zone approximately corresponding to the root zone of the vegetation. Most of the groundwater flow and the transport of the contaminants occur through a few widely spaced (10-50 m) permeable regions. The horizontal conductivities of these storm flow zones and the groundwater zones are subject to calibration. Two soil profiles which are used in the model are the silty clay loam and clay loam to a depth of 5 meters. The hydraulic conductivities and the soil moisture content of these soil types are also subject to calibration.

\subsubsection{Grid Size}

The objective of these series of simulations was to determine if variable grid cell size values of the model domain would have an effect on the computed discharge, surface and groundwater levels and depth of overland flow. Tests were performed using grid size to determine the most optimal conditions. Sufficient spatial resolution is required to show the contaminant plume in the Y-12 complex. The final simulations were obtained from a 
$50 \mathrm{~m}$ cell size with dimensions of 290 horizontal by 240 vertical cells (Roelant et al., 2009).

\subsubsection{Groundwater table}

Figure 13 shows the calculation of the groundwater table, including the vectors showing the groundwater movement in XY direction, for EFPC watershed. The groundwater tends to be parallel the topography of the watershed. The observed and computed values of the water table elevation are shown for three wells: GW-281 (Figure 14), GW-294 (Figure 15) and GW-276 (Figure 16).

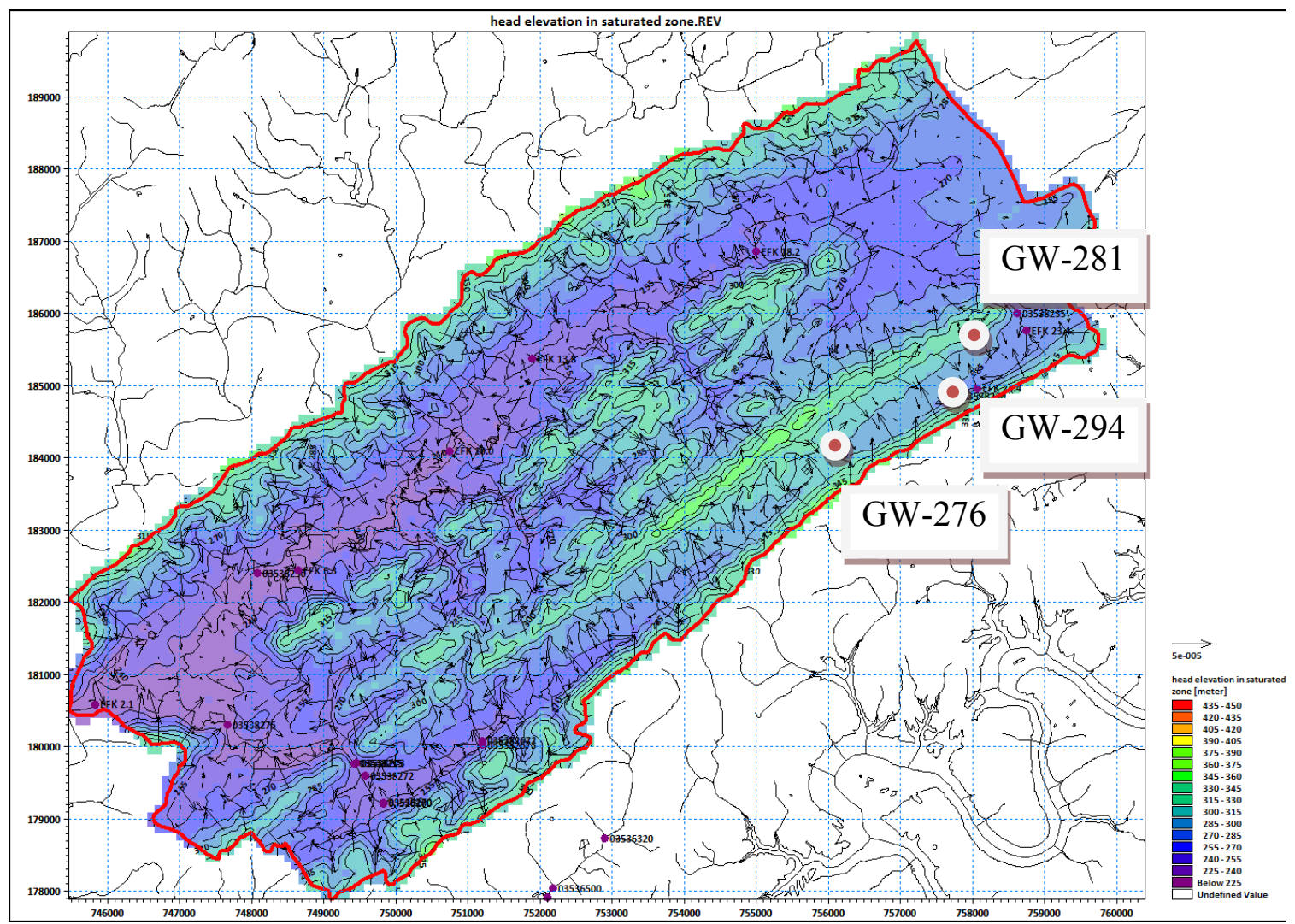

Figure 13 Calculated groundwater table elevations 


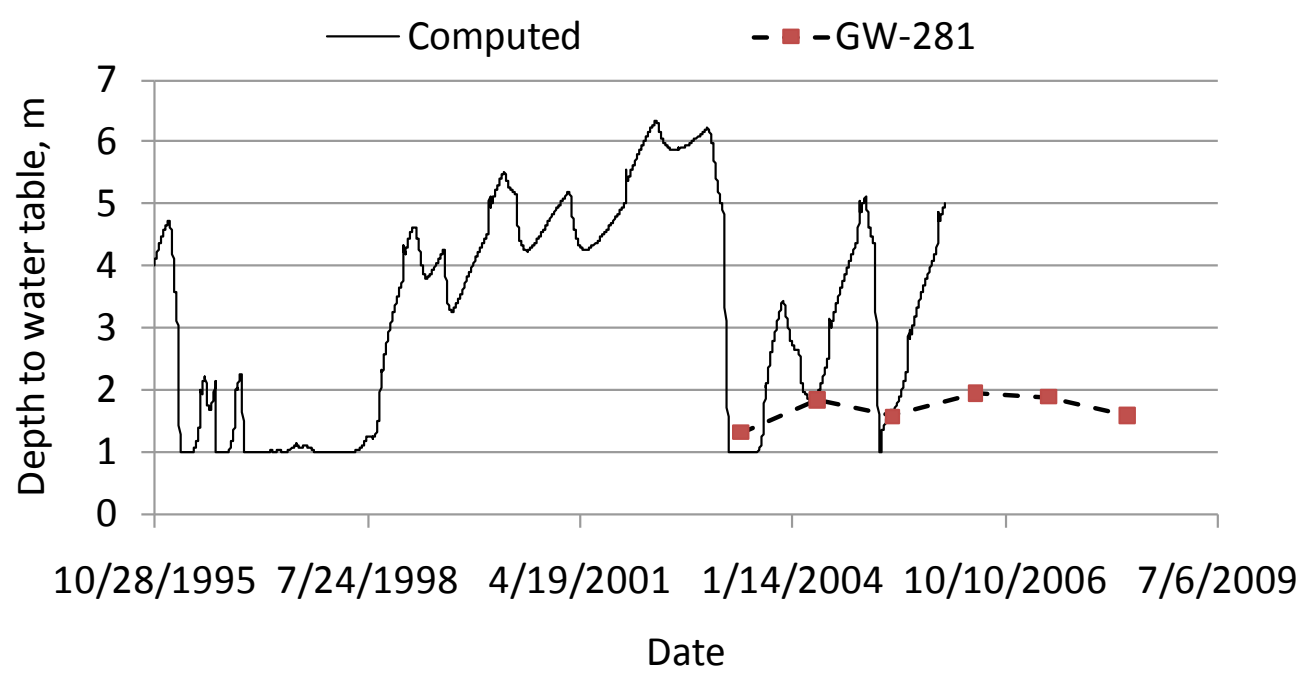

Figure 14 Observed and computed values for levels in GW-281

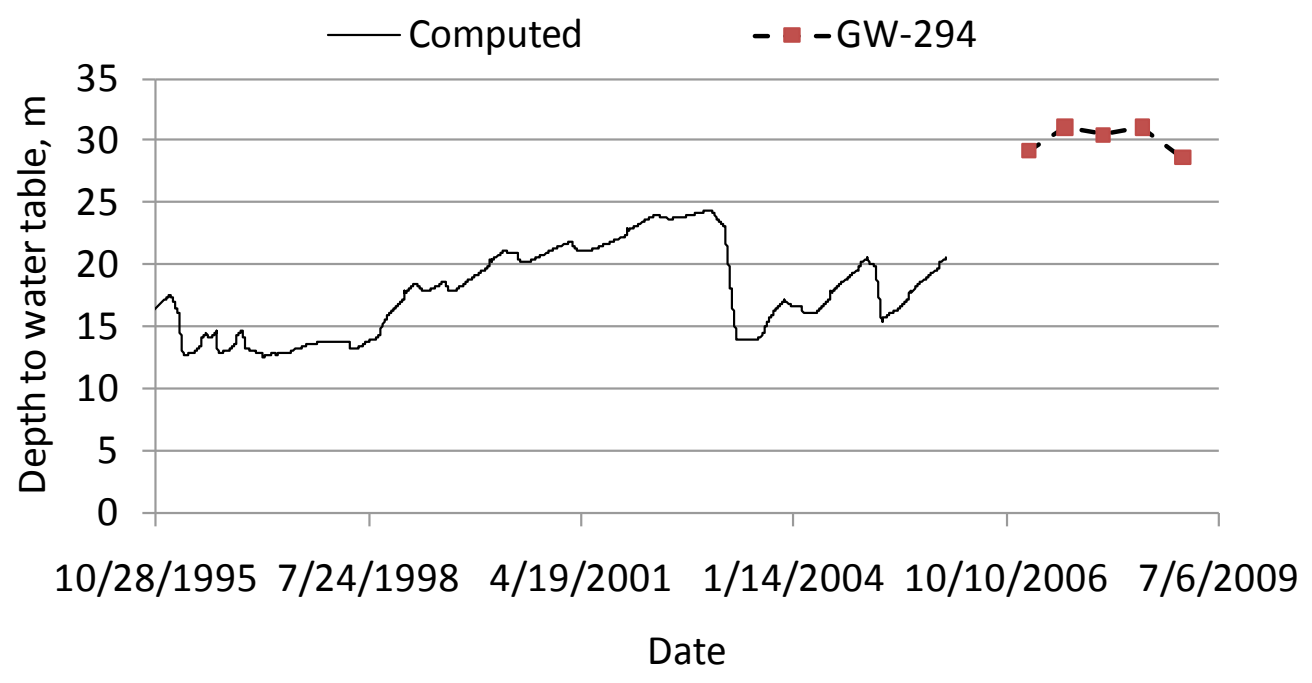

Figure 15 Observed and computed values for levels in GW-294 


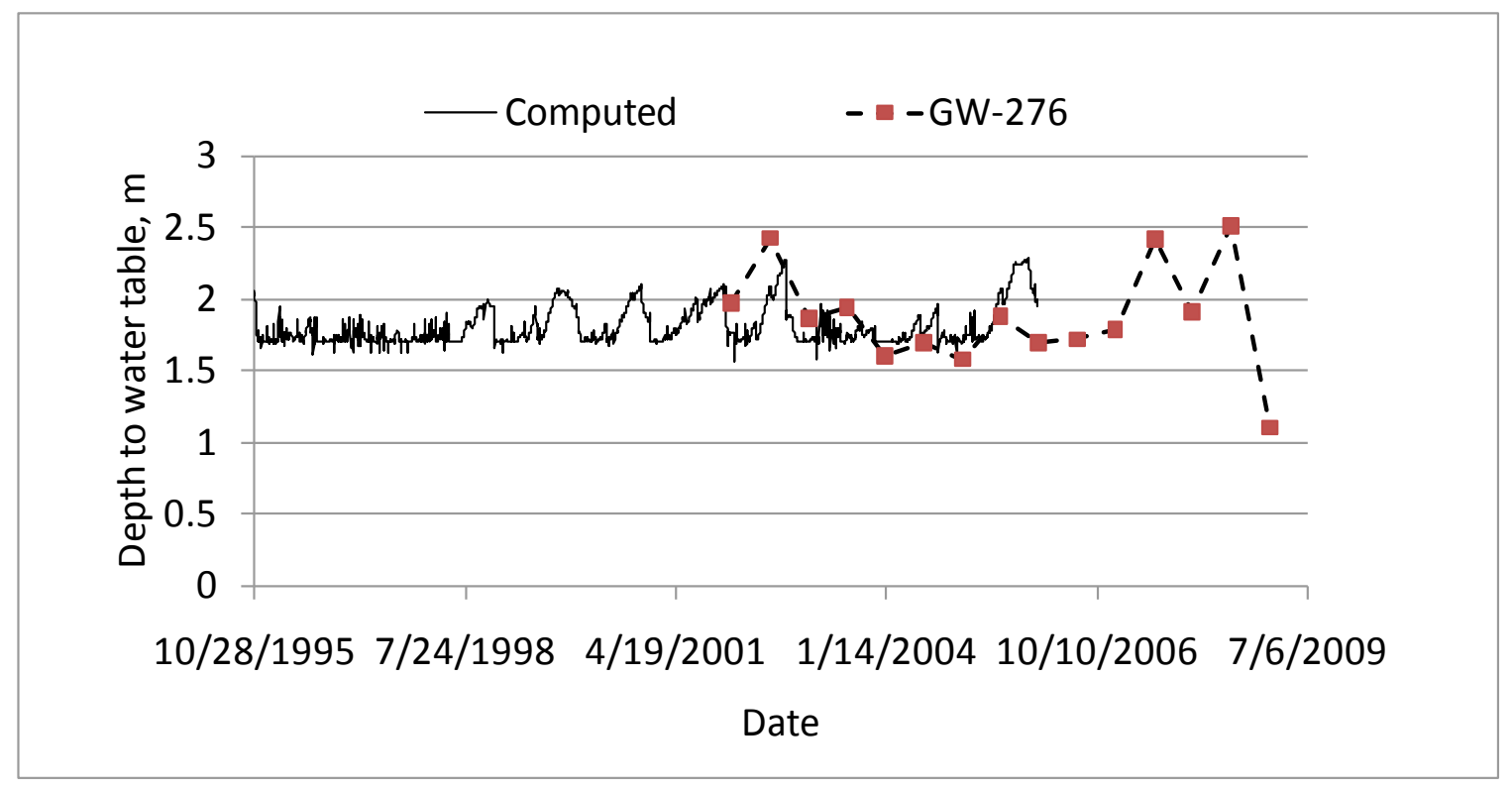

Figure 16 Observed and computed values for levels in GW-276

All groundwater table calculations were within the range of expected values. Groundwater table calculations also showed expected hydrologic responses in well GW276 which is primarily influenced by recharge.

\subsubsection{Hydrologic simulations}

The flow model calibration was carried out by performing hydrologic simulations. The flow fields were computed for a fifty year period (1951-2001) using the calibrated model. Simulations of advection-dispersion were conducted with the computed flow fields (including overland, subsurface and river flow).

The model has been calibrated using historical hydrological data. More details for the results obtained from the simulations and comparison with the discharges from each station are shown below. 


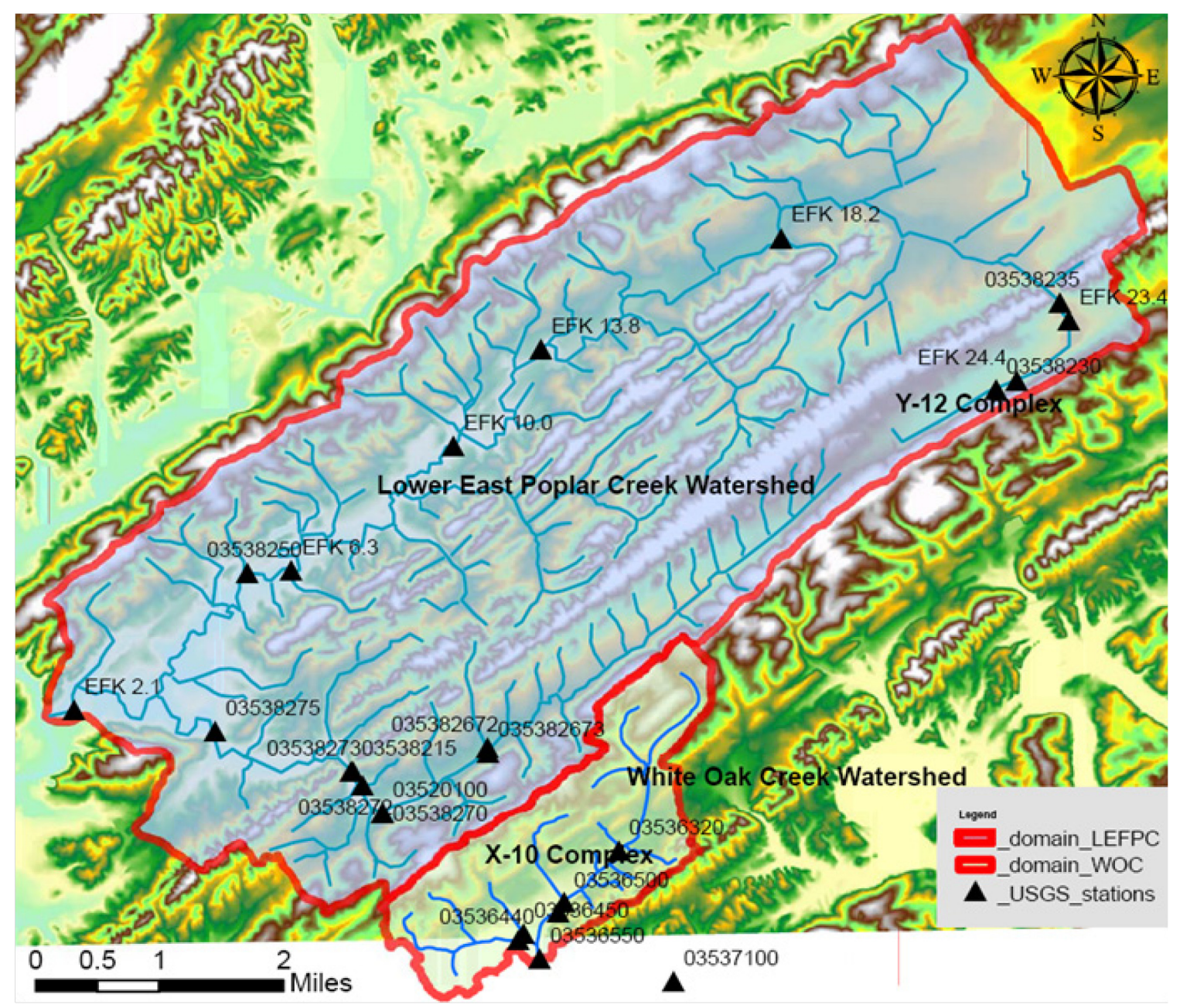

Figure 17 Location of USGS Stations and DOE stations used for data comparison

Available data was obtained from Tennessee StreamStat for Latitude (NAD83):

35.9189 (35 55 08) and Longitude (NAD83): -84.3168 (-84 19 00). The locations of the USGS stations are shown in Figure 17. 


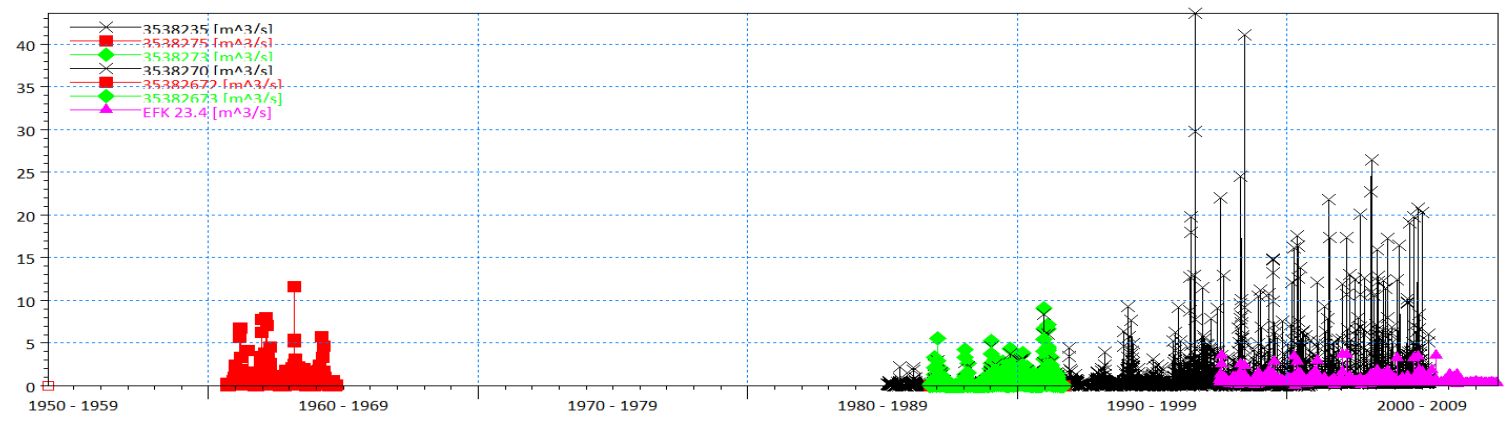

Figure 18 USGS stations used for calibration of discharges in EFPC streams

Figure 18 shows the discharge data from various USGS stations that were used to calibrate the flow model and Table 7 lists the physical characteristics of the EFPC.

Table 7 Physical characteristics of EFPC

\begin{tabular}{|cccc|}
\hline Characteristic Name & Value & Units & Reference \\
\hline Drainage_Area & 19.5 & square miles & a \\
\hline Main_Channel_Length & 12.65 & miles & a \\
\hline Mean_Basin_Elevation & 910 & feet & a \\
\hline Shape_Factor & 0.121857864 & dimensionless & b \\
\hline Percent_Forest & 24.2 & percent & a \\
\hline Percent_Storage & 0 & percent & a \\
\hline Soil_Infiltration & 3.89 & inches & a \\
\hline Stream_Slope_10_and_85_Method & 12.87 & feet per mi & a \\
\hline Tennessee_Climate_Factor_2_Year & 2.248 & dimensionless & b \\
\hline Tennessee_Physiographic_Factor & 0.737544002 & dimensionless & b \\
\hline \multicolumn{4}{r}{ Data from: a. (Moore, 1988) } \\
& b. (Sarkar, Essington et al., 1999) & \\
\hline
\end{tabular}

Available discharge data at USGS 03538230 was obtained from Tennessee StreamStat (USGS, 2007) for Latitude (NAD83): 35.9189 (35 55 08) and Longitude (NAD83): -84.3168 (-84 1900$)$. 


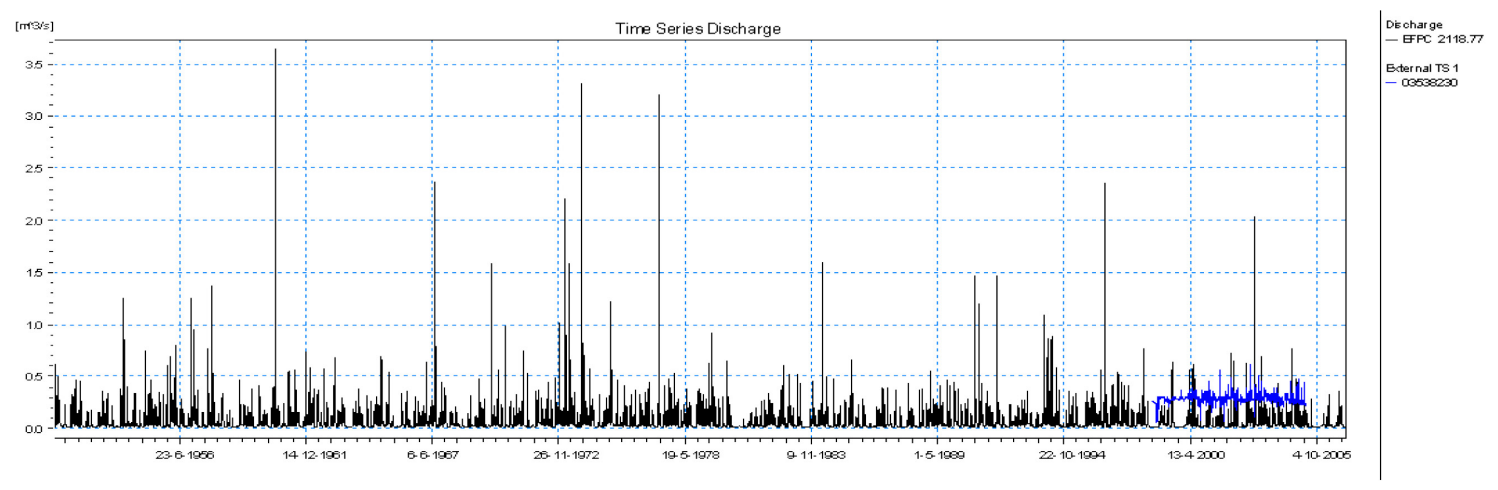

Figure 19 Computed and observed discharge values at USGS station 03238230

The blue line shows the observed discharges, which had a baseline of approximately $0.30 \mathrm{~m}^{3} / \mathrm{s}$. The model did not account for this baseline, which is most likely a result from additional discharges in the river.

The duration curve for EFPC 2119 (near EFK 24.4, and USGS station 03538230) is shown Figure 20, illustrating the actual values in black, the Cumulative Time (CT) in red, and the Maximum Continuous Period (MCP) in blue.

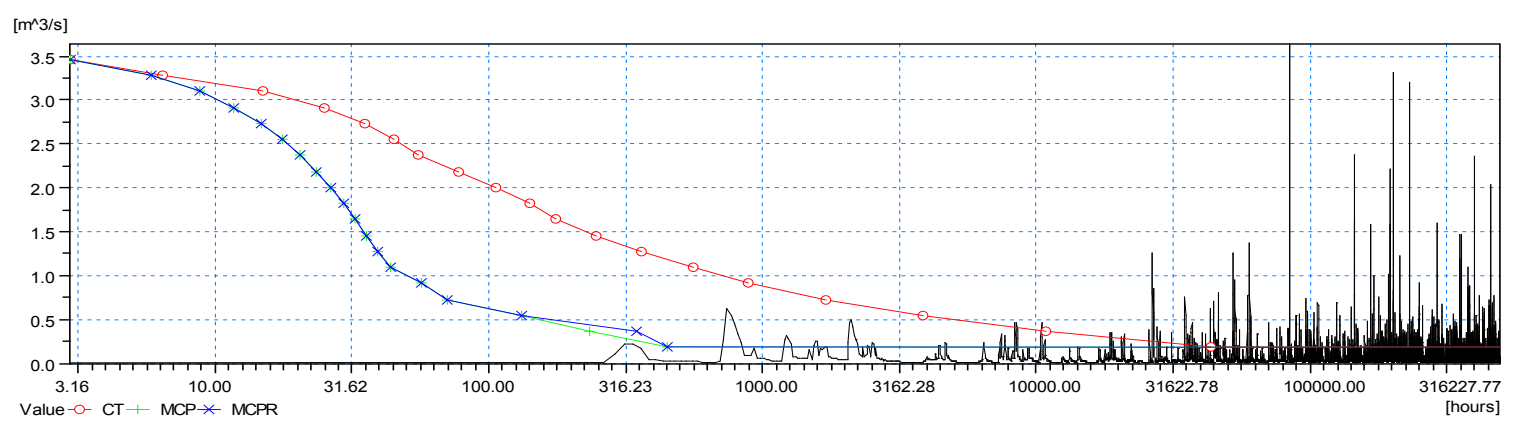

Figure 20 Duration curve computed for EFPC 2119

Computed data was compared with measurements from USGS station 03539235 and Station 17 (EFK 23.4) which is positioned approximately 0.2 miles downstream. 


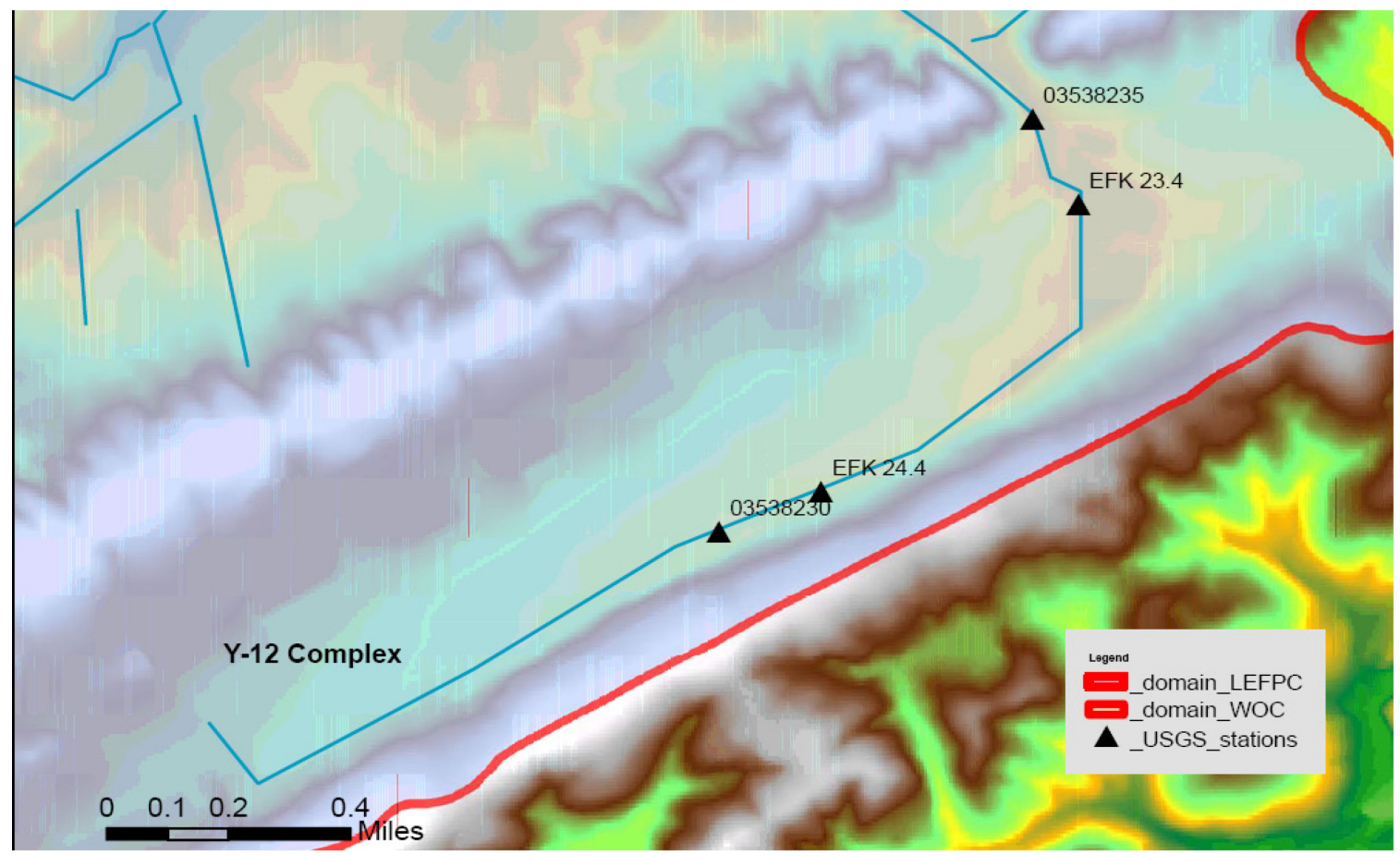

Figure 21 Location of USGS station 03538235 and Station 17 (EFK 23.4)

Figure 22 shows how the computed discharges at EFPC 3209 compare with the measured discharges at EFK 32.4 (in green) and at USGS station 03538235 (in blue).

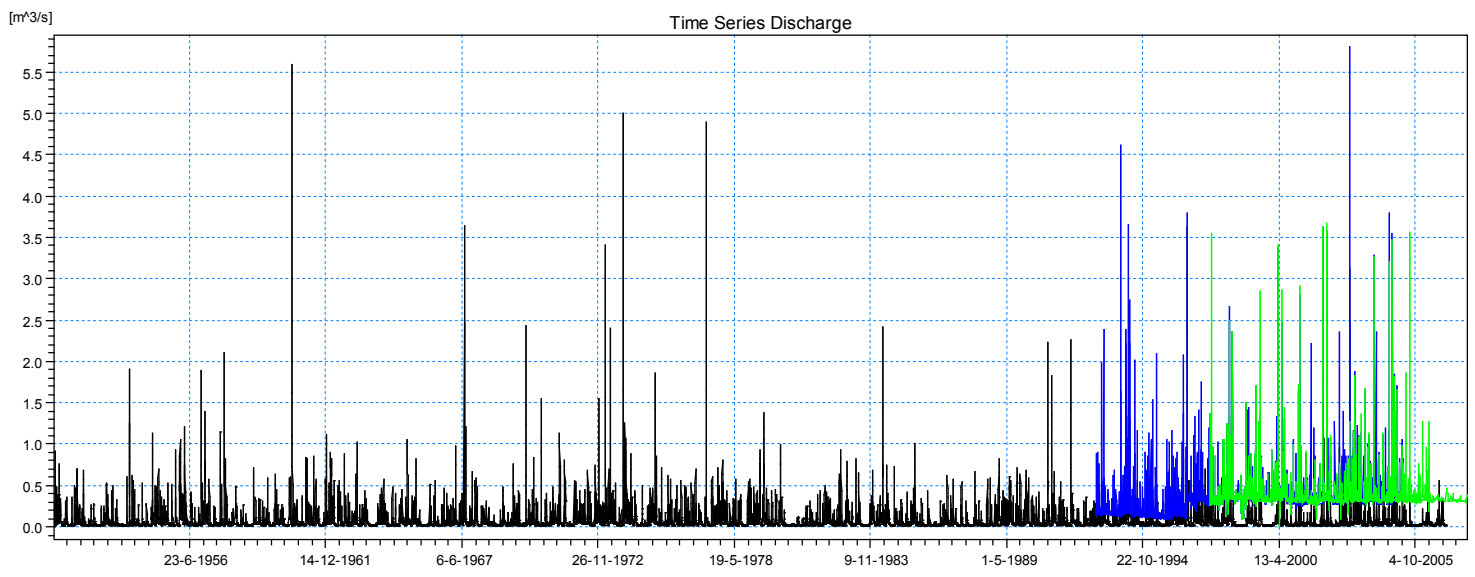

Figure 22 Computed and measured discharges at EFPC 3209, EFK 23.4, and USGS station 03538235 


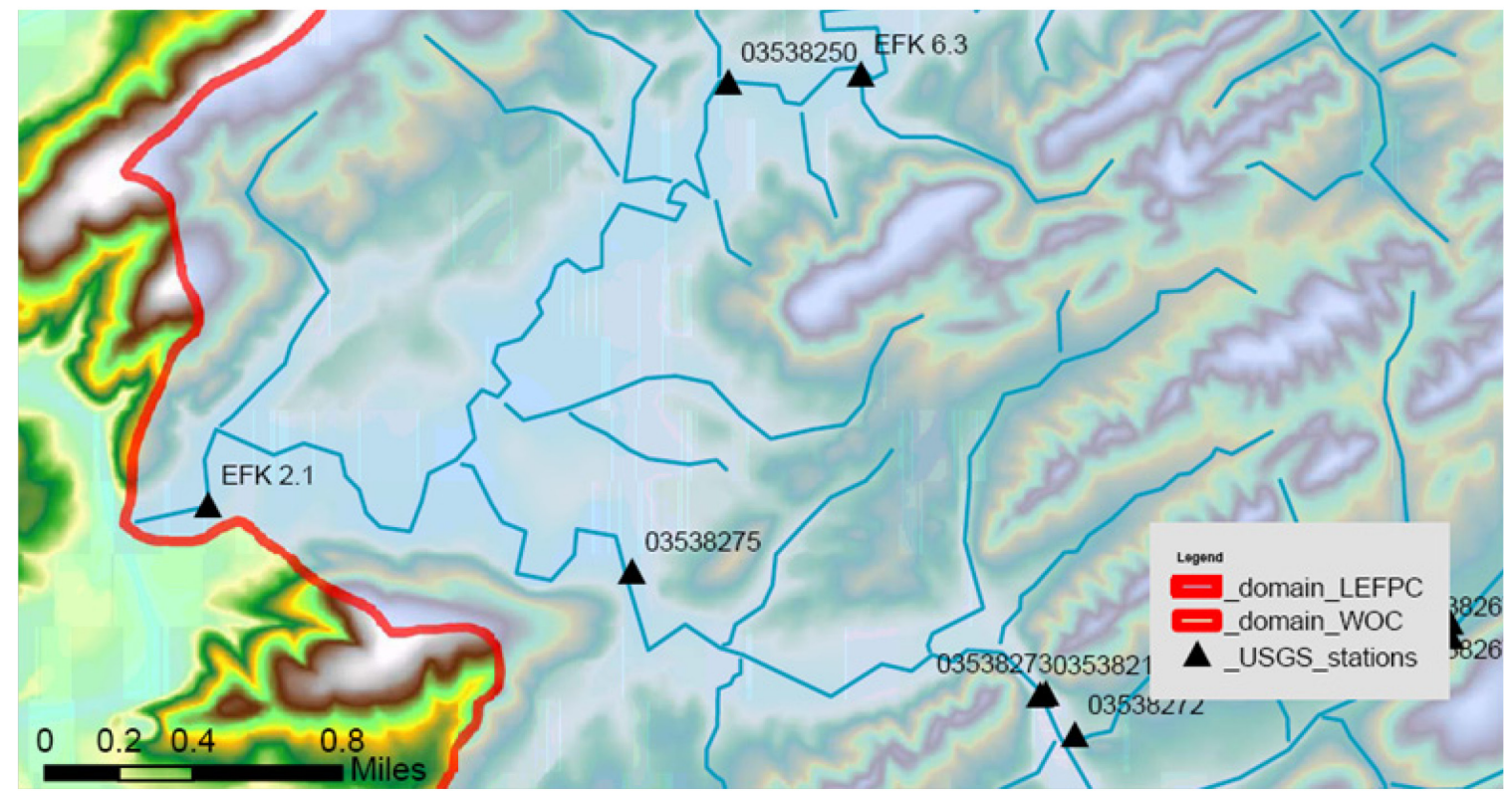

Figure 23 Location of USGS station 03538250

The duration curve for EFPC 3209 (near EFK 23.4, and USGS station 03538235) is shown Figure 24, illustrating the actual values in black, the Cumulative Time (CT) in red, and the Maximum Continuous Period (MCP) in blue.

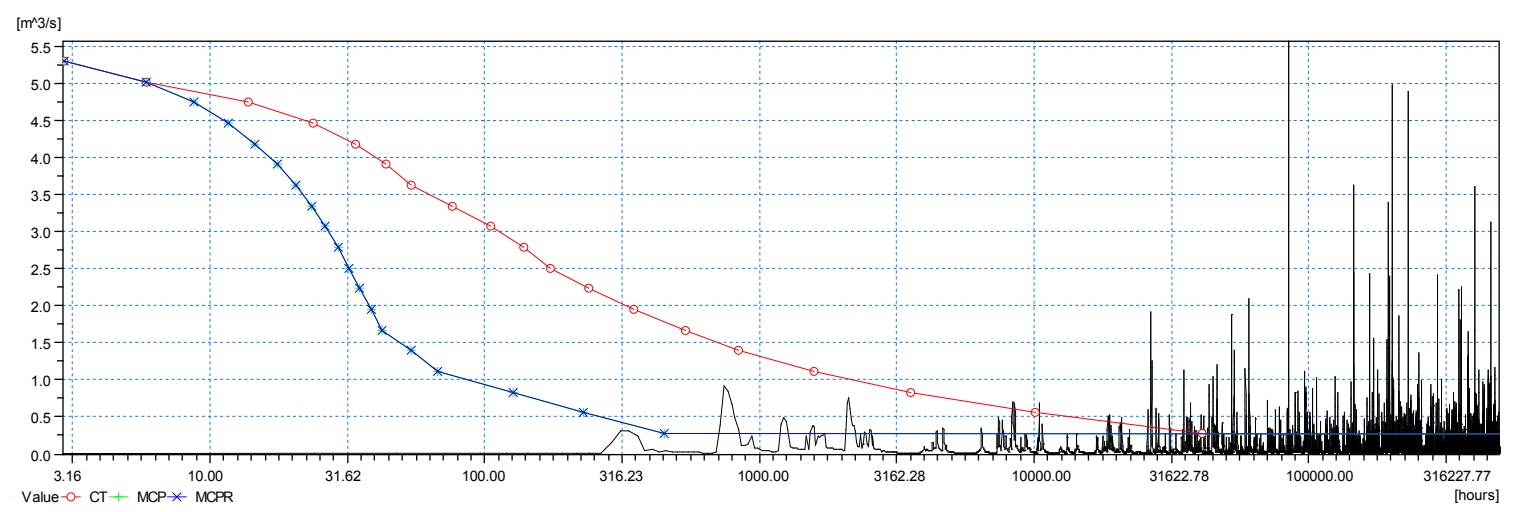

Figure 24 Duration curve computed for EFPC 3209

The discharges at USGS station 03538250, 0.4 miles downstream of EFK 6.3 (the location of these stations is shown on Figure 23) have been compared with computed values. 


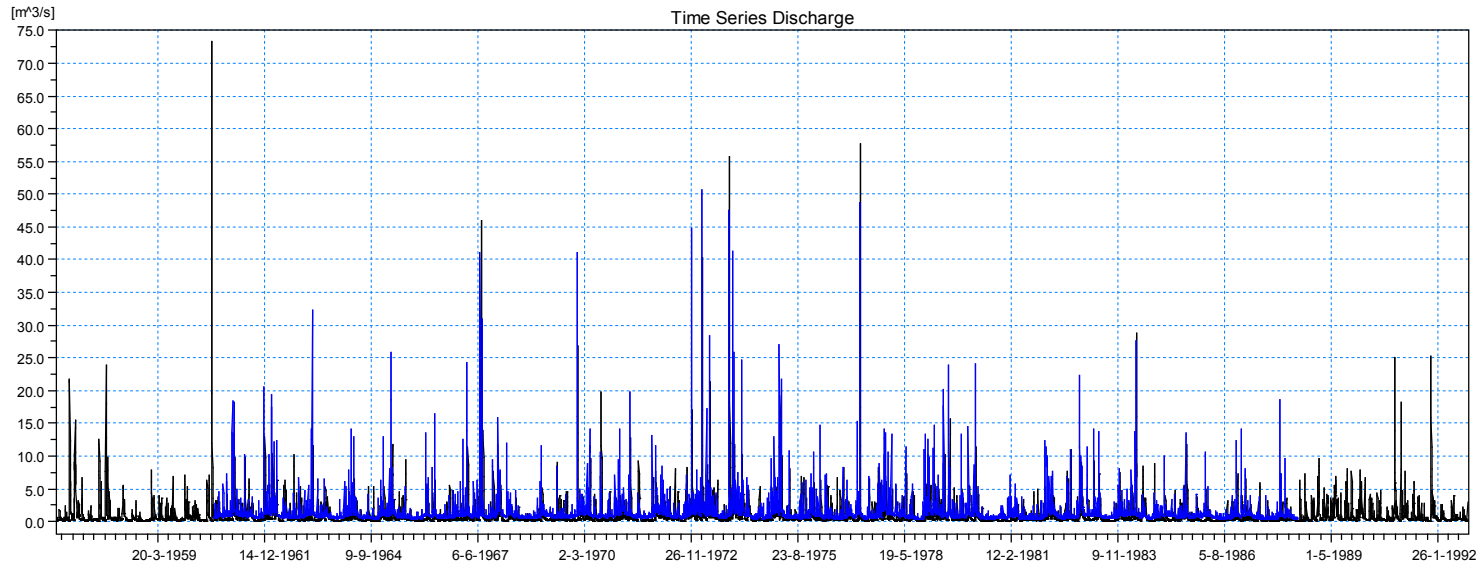

Figure 25 Computed and measured discharges at EFPC 20267 and USGS station 03538250

The data in Figure 25 shows excellent match between computed (in blue) and observed (in black) values. The duration curve for EFPC 20267 (near EFK 6.3, and USGS station 03538250) is shown Figure 26, illustrating the actual values in black, the Cumulative Time (CT) in red, and the Maximum Continuous Period (MCP) in blue.

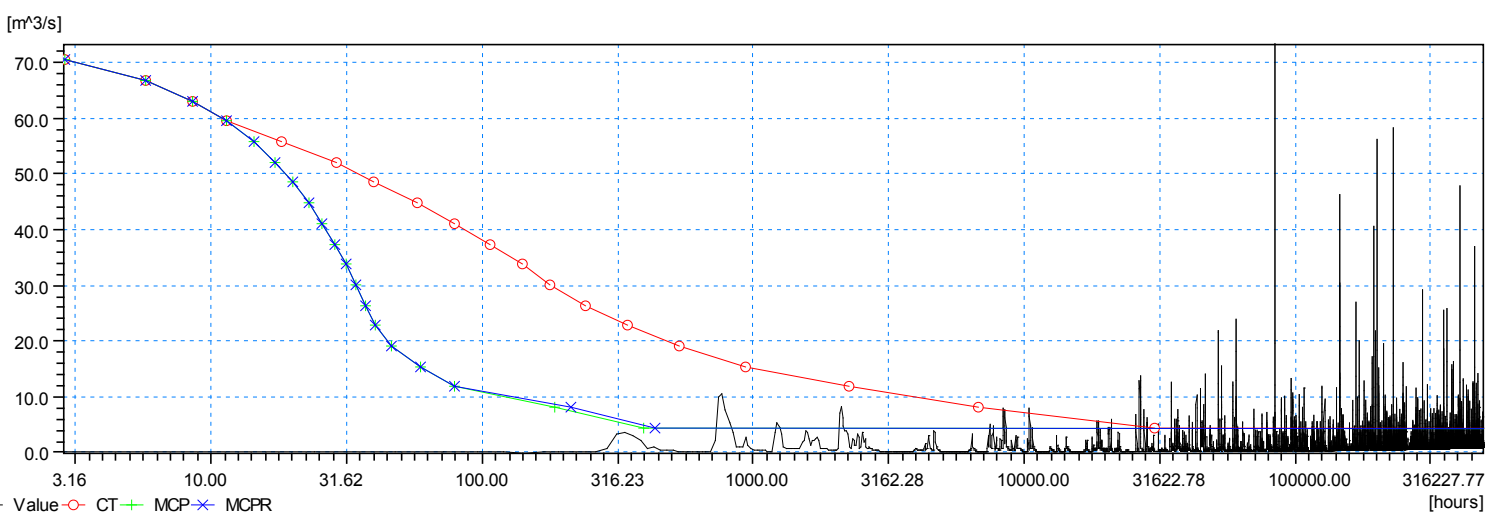

Figure 26 Duration curve computed for EFPC 20267

A plot of the cumulative distribution functions of EFPC 20267 and USGS station 03538250 (near EFK 6.3) is shown on Figure 27. 


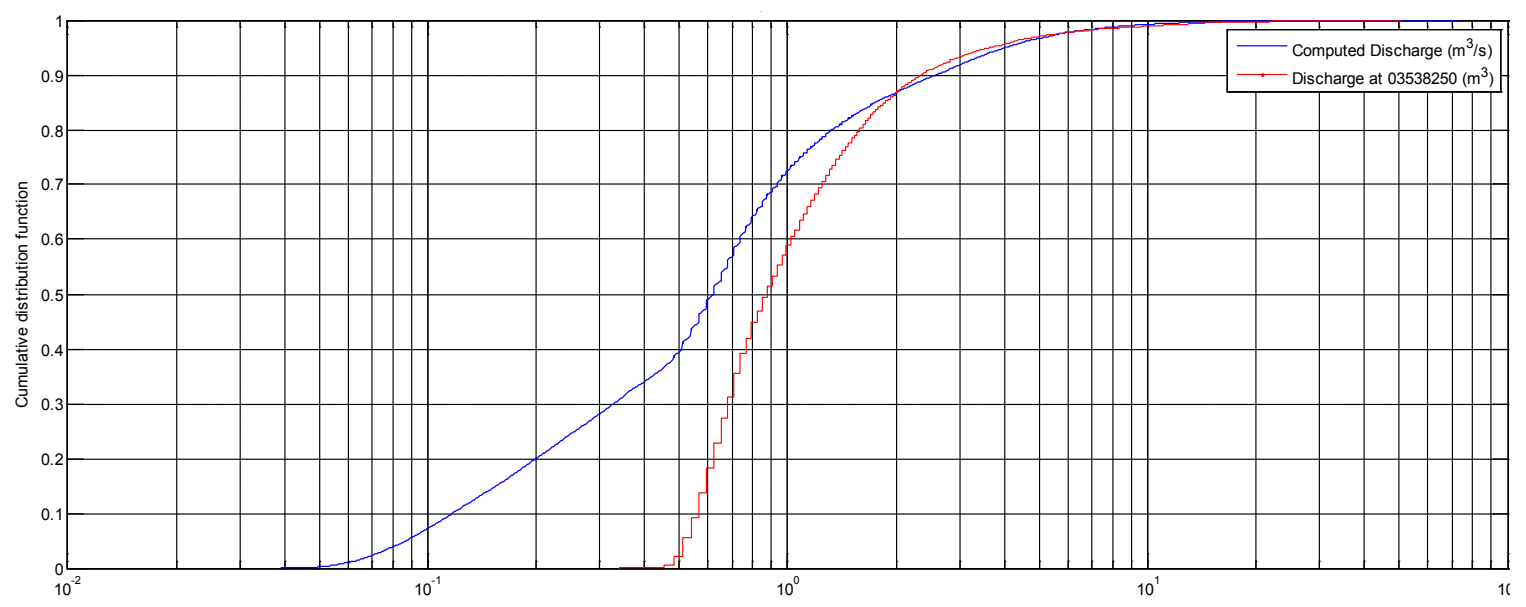

Figure 27 Cumulative distribution of computed and observed discharge at EFPC 20267

The boxplot in Figure 28 shows that there is a discrepancy between the average values of computed (respectively $0.6 \mathrm{~m}^{3} / \mathrm{s}$ vs. $0.9 \mathrm{~m}^{3} / \mathrm{s}$ ) which also shows a difference of approximately $0.3 \mathrm{~m}^{3} / \mathrm{s}$, most likely a result of adding water upstream for dilution.

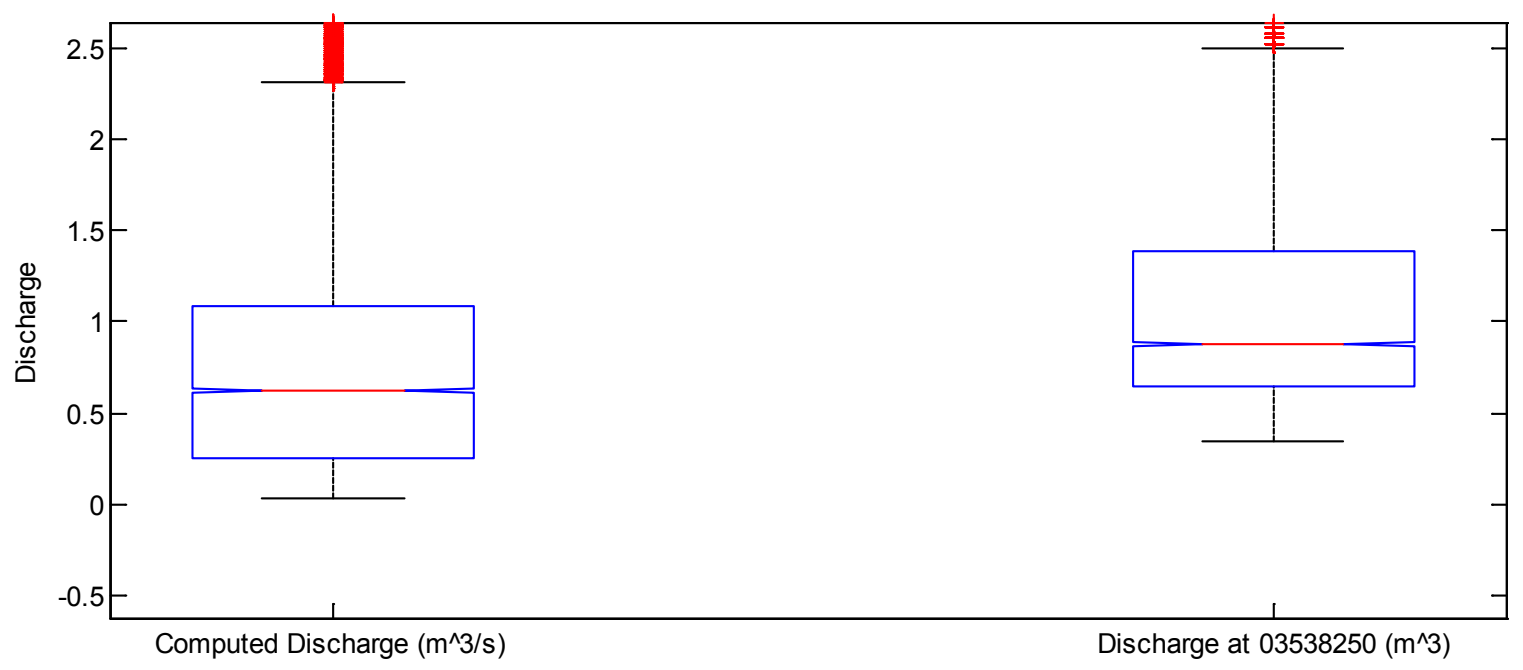

Figure 28 Boxplot of Computed and observed discharge at EFPC 20267

EFPC stream data, including flow duration, flow statistics, and baseflow statistics, are found in the Appendices (see Table 10, Table 11, Table 12, Table 13, and Table 14). 


\section{DEVELOPMENT OF THE MERCURY TRANSPORT MODEL}

The MIKE SHE advection-dispersion (AD) module is comprised of four independent components, each describing the transport processes in one of the parts of the hydrological cycle, including overland transport, transport in rivers (MIKE 11), transport in the vadose zone, and transport in the saturated zone. A number of processes relevant for simulating reactive solute transport are included in MIKE SHE including: water and solute transport in macro pores, sorption of solutes described by either equilibrium sorption isotherms (Linear, Freundlich or Langmuir) or kinetic sorption isotherms, which include effects of hysteresis in the sorption process, attenuation of solutes described by an exponential decay, and plant uptake of solutes. This model did not consider plant uptake and kinetic sorption. More description of the model is provided in the next sections. The model allows simulation with constant flow field (selected by the user), recycled flow field (the period is selected by the user) or complete flow field. The AD module uses the flow fields computed by the hydrological model.

\subsection{Mercury TMDL}

The Clean Water Act and associated regulations require each State to determine which waters do not meet water quality standards applicable according to their uses. Total Maximum Daily Loads (TMDLs) are required for pollutants violating these standards. To comply with these regulations the Tennessee Department of Environment and Conservation is developing the Mercury TMDLs in East Fork Poplar Creek watershed (EPA, 2008). The basis of that effort has been the development of a Load Duration Curve for Station 17 on the Y-12 complex using measured daily discharges and Total Mercury concentrations. 
Although $\mathrm{Hg}$ concentration in water data is available in some stations, many stream reaches on the watershed have no time series discharge and concentration data that would support developing a similar TMDL analysis throughout the watershed. In order to extend the development of TMDLs to other locations on the watershed, a mercury fate and transport model, capable of predicting $\mathrm{Hg}$ concentrations and mass accumulations along the stream reaches of the EFPC watershed, must be developed.

A number of other studies have reported use of models to support TMDLs in watersheds. Ambrose and Wool (2001) have developed TMDLs for mercury in six south Georgia rivers and the Savannah River using the GIS-based Watershed Characterization System (WCS), a mercury delivery spreadsheet was developed, and a water pollutant fate model was developed. These models compute mercury buildup in watershed soils, loading and delivery through the watershed and mercury fate in the main streams. Results were compared against survey data gathered during drought conditions. Despite environmental variability and scientific uncertainties, calculated mercury concentrations in soils, sediment, and water compared reasonably well with the observed data.

The EPA has recently developed the TMDL Modeling Toolbox (Scurlock et al., 2001). This set of software tools is a collection of models and databases that have been used independently in the past to develop TMDLs, including QUAL2K for Stream Water Quality, WAMView Watershed Assessment Model, Water Quality Analysis Simulation Program (WASP) and other tools. According to the EPA (Scurlock et al., 2001), the Toolbox models and databases have been used to develop TMDLs for a number of issues like pathogens, sediment, nutrients, dissolved oxygen, metals, temperature, and toxicants. Mercury TMDLs were developed in Georgia using WCS Mercury Tool and WASP. 
The USGS's Western Geographic Science Center, in collaboration with researchers at Stanford University, are developing an adaptive-management approach at the regional watershed scale to assist wastewater-treatment plants in meeting mercury dischargepermit requirements under TMDL guidelines (Wood et al., 2005). Their study chose statistical models to explicitly state and reduce, where possible, inherent uncertainties in physical, chemical, and biologic processes controlling the fate and transport of $\mathrm{Hg}$ in aquatic environments. In addition, Wood et al. (2005) developed and validated their approach with data from the Cache Creek subbasin of the Sacramento River watershed, in north-central California.

North Carolina Department of Environment and Natural Resources developed TMDLs to address fish consumption advisories for mercury in the Cashie River, a tributary to Albemarle Sound (Roanoke River Basin) in Bertie County, North Carolina (NC DENR, 2004). They used a linked-model approach to estimate the linkage between external mercury loads from the Cashie River watershed and $\mathrm{MeHg}$ exposure concentrations in the river. Loads from atmospheric and watershed sources were simulated with the WCS Mercury Load Estimation Tool. River transport processes were modeled with the WASP-TOXI model. Using this model combination they studied the existing load and stream assimilative capacity, Waste Load, and Load Allocations, and proposed a TMDL implementation plan. The above examples indicate that there is a great potential in using modeling tools to support TMDL development in the Oak Ridge watersheds.

In this project, the MIKE SHE integrated hydrologic and mercury fate and transport model are applied to analyze how $\mathrm{Hg}$ remediation strategies affect the water quality of 
the EFPC watershed. This would extend the existing TMDL approach to other parts of the watershed where presently there is no possibility to have it for lack of adequate data. The MIKE SHE model for the East Fork Poplar Creek watershed was compiled with the objective to provide an assessment of the watershed assimilative capacity, critical conditions, and insight of future scenarios allowing evaluation of remediation options and environmental management plans for the EFPC Watershed.

\subsection{Transport Parameters}

The sorption type that MIKE SHE accepts can be equilibrium or equilibrium-kinetic. In the first case, the sorption is assumed to be instantaneous. In the second case, the sorption is rate dependent. This model assumed instantaneous sorption type (equilibrium). The equilibrium isotherm can be either a linear, or a non-linear isotherm (Freundlich or Langmuir). The model used a linear sorption isotherm which can be described as a linear relationship between the amount of solute sorbed onto the soil material and the aqueous concentration of the solute, where $K_{d}$ is the distribution coefficient. Transport parameters used in the model are shown in Table 8 and are described in detail in the following sections.

Table 8 Transport parameters used in the model

\begin{tabular}{|cccc|}
\hline Input Data & $\begin{array}{c}\text { EUM autotype } \\
\text { in dfs file }\end{array}$ & $\begin{array}{c}\text { Typical values and base } \\
\text { unit for constant values }\end{array}$ & Value \\
\hline distribution coefficient & $\mathrm{K}_{\mathrm{d}}$ value & {$[\mathrm{mL} / \mathrm{g}]$} & $500-520$ \\
\hline effective porosity & Porosity Coef. & fraction between 0 and 1 & $0.4-0.1$ \\
\hline matrix porosity & Porosity Coef. & fraction between 0 and 1 & $0.1-0.04$ \\
\hline diffusivity (SZ, UZ) & $\begin{array}{c}\text { Dispersion } \\
\text { Velocity Factor }\end{array}$ & {$[\mathrm{m}]$} & 0.005 \\
\hline source location & Grid Codes & {$[$ integer codes $]$} & spatial \\
\hline $\begin{array}{c}\text { diffusion coefficient } \\
(\text { OC, River) }\end{array}$ & $\begin{array}{c}\text { Dispersion } \\
\text { coefficient }\end{array}$ & {$\left[\mathrm{m}^{2} / \mathrm{s}\right]$} & $6 \mathrm{e}-008$ \\
\hline
\end{tabular}




\subsubsection{Distribution coefficient}

In natural systems, metals may undergo sorption reactions with the solid matrix with which the water is in contact, i.e. the aquifer or saturated soil column. The metal partition coefficient, $\mathrm{K}_{\mathrm{d}}$, is a ratio of the sorbed metal concentration (usually in terms of mg of metal per $\mathrm{kg}$ of sorbing material) to the dissolved metal concentration (usually in terms of mg of metal per L of solution) at equilibrium (Allison, 2005).

For typical environmental conditions $(\mathrm{pH}>6$ and dissolved oxygen greater than 0.2 $\mathrm{mg} / \mathrm{L}$ ), the most abundant species is $\mathrm{Hg}(\mathrm{II})$. Furthermore, in aqueous solution $\mathrm{Hg}$ (II) is not a free metal and is always complexed with a variety of ligands including chloride and dissolved organic material. The complexed mercury species are in equilibrium with the soil mercury species depending on the stability constant of mercury with the ligands. The equilibrium between sorbed species in soil and aqueous complexed mercury is linear and is expressed through a soil-water partition coefficient. A $\mathrm{K}_{\mathrm{d}}$ value for $\mathrm{Hg}$ (II) was determined from experimental work using ORR soils and it was in the range of 508-511 $\mathrm{mL} / \mathrm{g}$ (or $\log \mathrm{K}_{\mathrm{d}}$ of $2.706-2.708 \mathrm{~mL} / \mathrm{g}$ ) (Katsenovitch, 2009). This value is slightly lower than the results for the statistical analysis prepared by Allison and Allison in 2005 for the EPA which estimates a soil/soil water partition coefficient, or $\log \mathrm{K}_{\mathrm{d}}$, for $\mathrm{Hg}(\mathrm{II})$ from 2.2 $-5.8 \mathrm{~mL} / \mathrm{g}$ with a mean of $3.6 \mathrm{~mL} / \mathrm{g}$. The mean for the methylmercury for $\log$ of the soil/soil water partition coefficient was $2.7 \mathrm{~mL} / \mathrm{g}$, which corresponds well with the lab results for ORR soils.

The range of $K_{d}$ values used for the model was from $100-5000 \mathrm{~mL} / \mathrm{g}$ and was optimized to create a best fit for Station 17 data using visual estimation of the timeseries. The total mercury $\mathrm{K}_{\mathrm{d}}$ value used in the final transport model was $500 \mathrm{~mL} / \mathrm{g}$, which is 
within $10 \%$ agreement of the literature data.

\subsubsection{Effective porosity}

Fluxes of water are automatically read from a flow result file according to the storage frequency in the specified simulation period. Together with these fluxes the effective porosity in the groundwater determines the advective velocity of the species. The effective porosity is in the range between 0 and 1 i.e. for porous media usually 0.15 to 0.3 depending of the grain size distribution (the more uniform the higher effective porosity) and for fractured media usually 0.01 to 0.05 . The effective porosity can be given either as a uniform value over the entire domain, or through a spatially distributed file (if necessary the porosity can be specified for each cell using a dfs 2 file). This model used a uniform distribution of 0.4 and a single layer.

\subsubsection{Matrix porosity}

Solutes in a fractured media will be transported by diffusion in and out of the soil matrix of the media causing fast breakthroughs and long tailings. This process was included in MIKE SHE AD by activating the dual porosity transport component (this required providing information about the matrix porosity and mass transfer coefficient of the medium). Matrix porosity is given as a value between 0 and 1 , which can be specified by either a uniform value for the entire area or distributed values using dfs 2 files. Matrix

porosities are generally very difficult to measure and application of this component may require calibration against breakthrough curves to give realistic estimates of the parameters. Furthermore, input should be the "effective" matrix porosity i.e. the matrix porosity that is "actively" involved in the solute diffusion. This can be significantly lower than the matrix porosity measured by core analysis. This model used a value of 0.04 
which is typical for a limestone aquifer (for a clay sample this factor can vary up to 0.30 or slightly below the effective porosity).

\subsubsection{Dual porosity transport}

This feature was used to describe solute transport in both the fractures and in the aquifer matrix. The exchange of mass between the fractures and the matrix is described by a diffusion process and the mass transfer coefficient controls rate of solute exchange between the two phases. As this coefficient is increased, solute diffusion takes place at a faster rate which causes lower peaks but a slower attenuation of the peak in a concentration break through curve. It is an empirical constant and cannot be compared directly with the diffusion coefficient for the species. Since the mass transfer coefficient is an empirical constant and varies both with the characteristics of the species and of the media it is difficult to determine its range. For initial simulations, the model used the diffusion parameters equal to $6 \mathrm{e}-008 \mathrm{sec}^{-1}$, which were in the range of the diffusion parameters, obtained from experimental work, (this parameter can be as low as 1e-012 $\left.\sec ^{-1}\right)$.

\subsubsection{Dispersion in $\mathrm{SZ}$}

The dispersion model allows two different options (isotropy and anisotropy with axial symmetry around the z-axis). Assuming isotropic conditions, only the longitudinal dispersivity, $\alpha \mathrm{L}=0.005 \mathrm{~m}$, and the transversal dispersivity, $\alpha \mathrm{T}=0.005 \mathrm{~m}$ were used. Under anisotropic conditions five dispersivity parameters are required, which depend on the degree of heterogeneity in the geology (and factors affecting the velocity field). Larger dispersivities are characteristic for greater heterogeneities of the geology. Furthermore, the magnitudes of the dispersivity factors depend on the scale of modeling and on the 
applied grid size. A larger scale will achieve larger dispersivities and a larger grid size will achieve smaller dispersivities, which are generally used because of numerical dispersion. The longitudinal dispersivity is recommended by DHI to be in the range of $1 \%$ or less of the travel distance, the transversal, horizontal dispersivity should be at least $2 \%$ of longitudinal and the transversal, vertical dispersivity should $1 \%$ of the transversal (DHI, 2008).

\subsubsection{Sources in SZ}

Sources can externally be introduced into the groundwater transport component in four different ways i.e. as a point or line (over depth) source in specific grids or as a spatially distributed source in a certain depth interval. In both cases the source can either be time varying flux of mass (mass/time [point or line] or mass/area/time [area source]) or fixed concentrations (mass/volume) which may vary in time: A point or line source is introduced by specifying the upper and lower layer and the $\mathrm{X}$ and $\mathrm{Y}$ co-ordinates of the horizontal location of the point ("grid") in the model coordinate system. A spatially distributed source is introduced by specifying the upper and lower layers and the spatial distribution as a dfs 2 file with code ' 1 ' in the source area and ' 0 ' elsewhere.

\subsubsection{Dispersivity for $\mathrm{UZ}$}

For UZ, which is 1-D, the dispersivity is specified as a single dispersivity value. Each of the input elements consists of a depth input indicating the depth in meters below ground surface to which the dispersion input is valid and the actual value to use which can be either a constant value or a dfs 2 file. The same comments as given for dispersion in groundwater apply for solute transport in unsaturated media. In unsaturated porous media recommended values for dispersivity are 0.1 meter for travel distances less than 2 
meters (DHI, 2008). The longitudinal dispersivity can be distributed over depth by specifying depth intervals (as described above).

\subsubsection{UZ sources}

Normally, solutes are introduced in the unsaturated zone by the precipitation, and MIKE SHE determines the infiltration rate and thereby the mass flux in the upper node. However, mass of solutes can externally be introduced into the unsaturated zone transport component in two other ways namely as a point or line source over a certain depth in a specific soil column (grid) or as spatially distributed source in a certain depth interval. In both cases the source is given as time varying flux of mass (mass/time or mass/area/time). A point or line source is introduced by specifying the upper and lower layer and the $\mathrm{X}$ and $\mathrm{Y}$ co-ordinates of the horizontal location of the point ("grid") in the model coordinate system. A spatially distributed source is introduced by specifying the upper and lower depth and the spatial distribution as a dfs 2 file with code ' 1 ' in the source area and ' 0 ' elsewhere. Input that varies with depth can be given in UZ over depth intervals i.e. the user specifies the depths (depth1, depth2, depthN as numbers) and the parameter distributions in the entire model area for that depth interval as a dfs 2 data file or a constant value. The parameters will then be uniform in each grid from soil surface to depth1 from depth1 to depth2 etc. until the bottom of the unsaturated zone is reached. While this method has the advantage of easily describing the vertical discretization, it does not take into account the discretization which can vary from one UZ column to the next. Source strengths are specified in the Species Dependent input part. 


\subsubsection{Dispersion in overland flow}

For the 2-D overland transport component two dispersion coefficients $\left(\mathrm{m}^{2} / \mathrm{s}\right)$ were specified, which were different from the dispersivity (m) used for SZ and UZ.

\subsubsection{Overland sources}

A point source was introduced by specifying the $\mathrm{X}$ and $\mathrm{Y}$ coordinates of the location of the point ("grid") in the model coordinate system. A spatially distributed source is introduced by specifying the spatial distribution as a dfs 2 file with code ' 1 ' in the source area and '0' elsewhere. Source strengths are specified in the Species Dependent input part.

\subsection{Mercury Transport Model Calibration}

The objective of the transport calibration was to provide maximum mercury concentration peak values that are within the range of the observed. This method improves the model to provide a more accurate simulation for toxicity calculations. The mercury linear $K_{d}$ value was varied based on matching measured peak mercury values at Station 17 with calculated peak values.

The calculated values at Station 17 were compared with measured values and the results showed magnitude of the peaks similar to measured values. The results for the period 1/1/2004-12/31/2004 are shown in Figure 29 (the red line is measured data at Station 17, blue line is calculated data at Station 17 and the purple line represents calculated concentrations at the watershed exit; the vertical axis is in parts per trillion). 


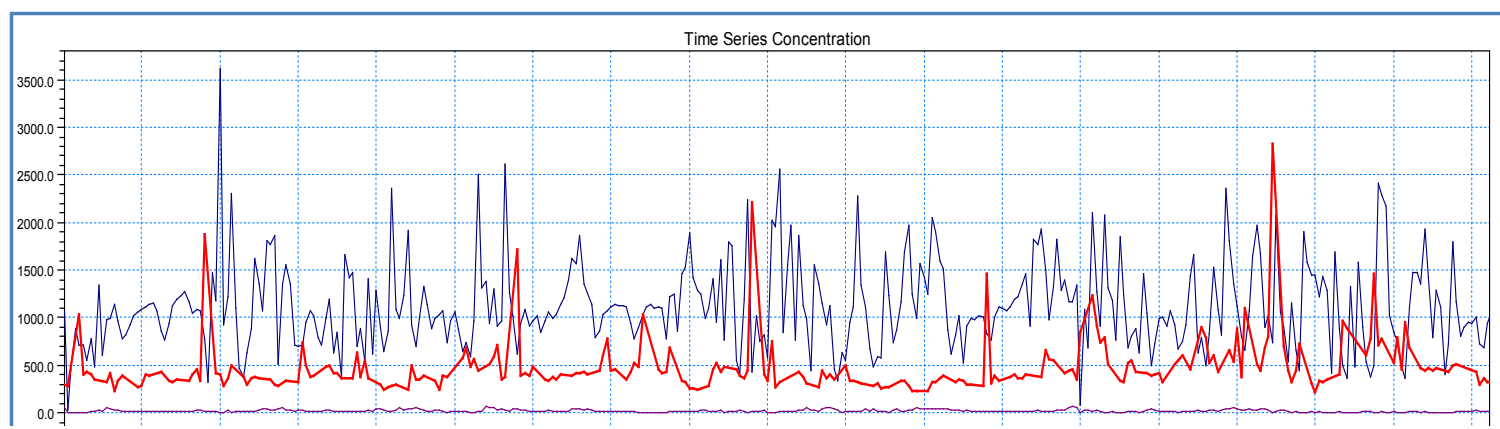

Figure 29 Observed and computed mercury concentration at Station 17

Figure 30 shows significant attenuation of mercury concentrations downstream EFPC (the result is consistent with dilution caused by downstream water addition), which may not be always valid considering that the model did not include sediment processes. The total mercury mass calculated for the year (in $\mathrm{kg}$ ) is shown below.
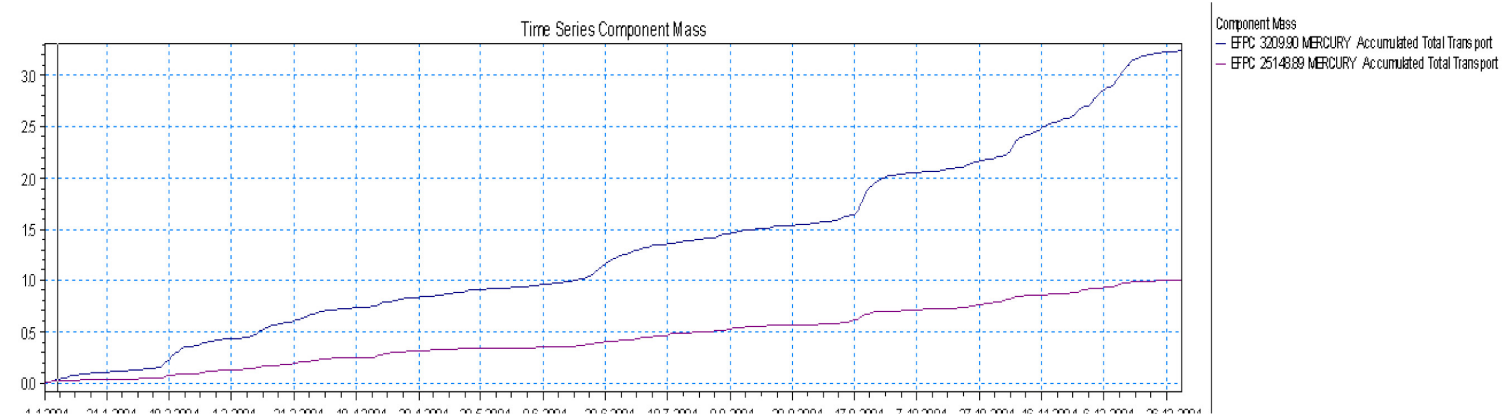

Figure 30 Observed and computed mercury at the outfall for existing conditions

The total mass accumulated at the watershed exit (shown in purple) by river transport is lower by a factor of 3 when compared with the accumulated mass at Station 17 (shown in blue). The mass balance shows that the difference is attributed to exchange with baseflow and sorption downstream. These results are ab initio, which need to be correlated to measured data downstream. Furthermore, the model can be improved by considering sediment transport in the EFPC streams.

Flow and load duration curves were determined for Station 17 which provides daily monitoring for flow and mercury concentrations. 


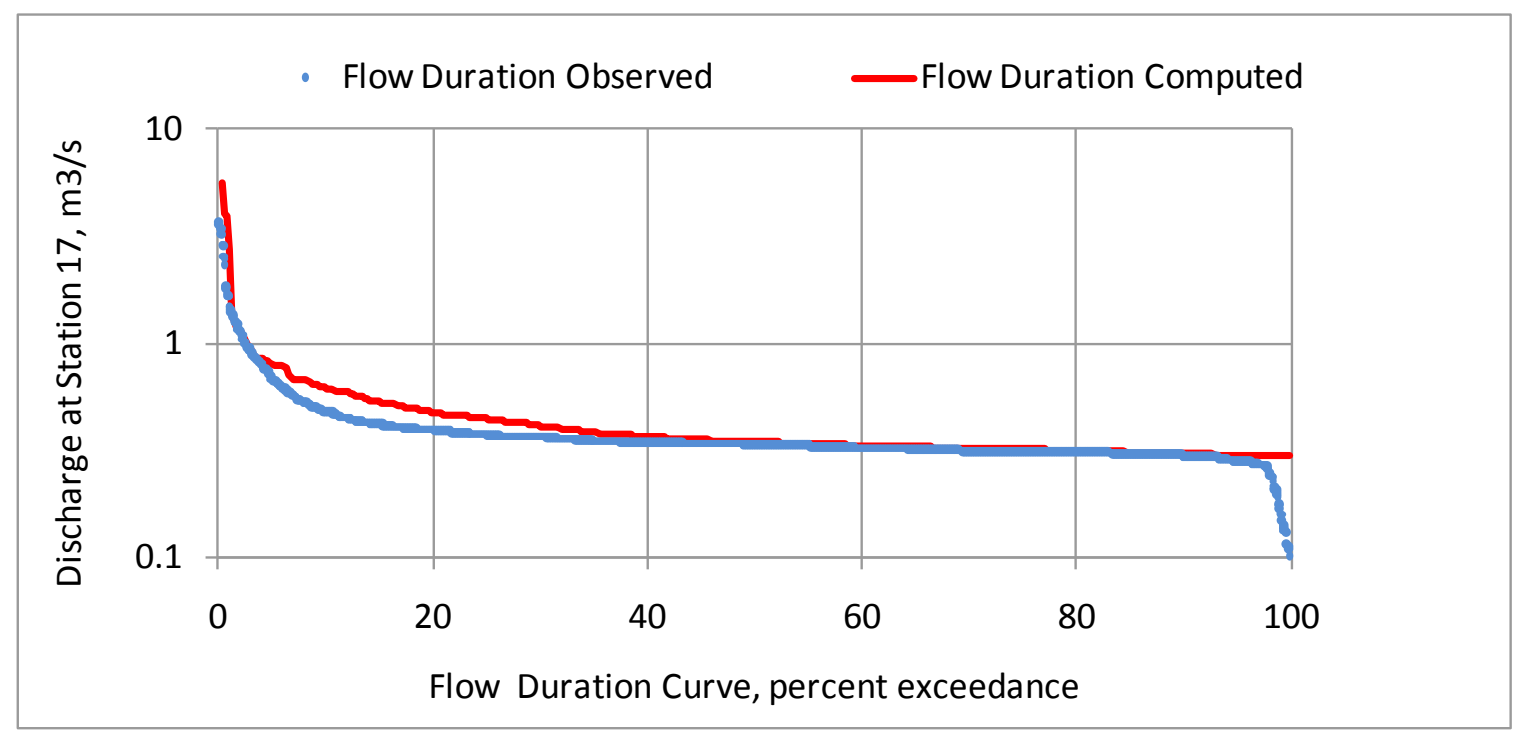

Figure 31 Flow Duration Curve at Station 17 (1997-2007)

Figure 31 shows the Flow Duration Curve for Station 17. It has an observed median of $11.0 \mathrm{cfs}$, observed average of $14.0 \mathrm{cfs}$, computed median of $12.35 \mathrm{cfs}(+4 \%$ difference), and a computed average of $15.95 \mathrm{cfs}(+14 \%$ difference).

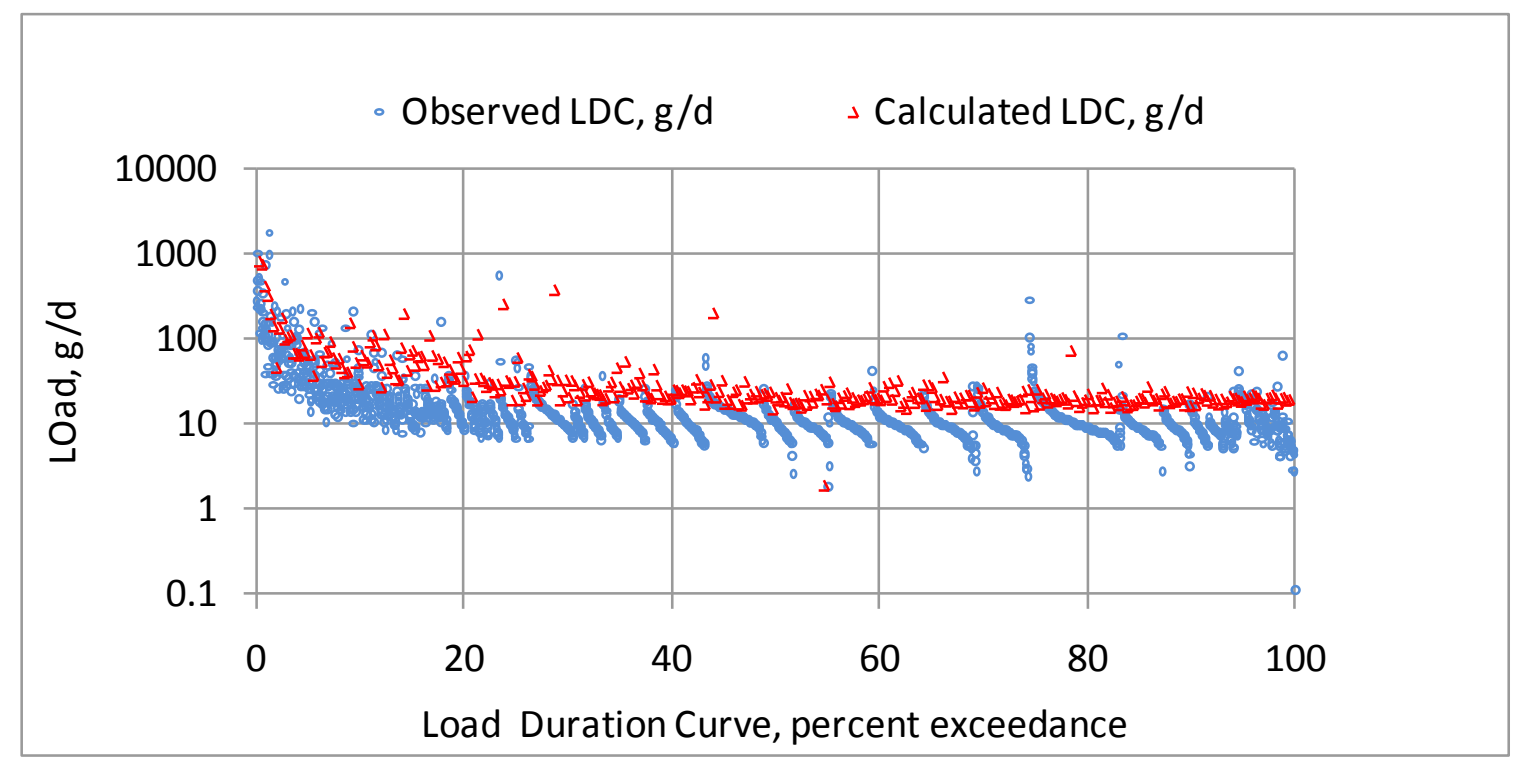

Figure 32 Load Duration Curve at Station 17 (1997-2007) 
Figure 32 shows the Load Duration Curve for Station 17. It has an observed median of $10.0 \mathrm{~g} / \mathrm{d}$, observed average of $20.6 \mathrm{~g} / \mathrm{d}$, computed median of $14.2 \mathrm{~g} / \mathrm{d}(+40 \%$ difference), and a computed average of $26.9 \mathrm{~g} / \mathrm{d}(+30 \%$ difference).

\section{SIMULATIONS OF MERCURY TRANSPORT}

The purpose of the mercury transport model simulations are to provide information about the effect of hydrological events on mercury transport and the effect of various remediation strategies on mercury concentration downstream East Fork Poplar Creek. Important components which define the concentration downstream include i) the mobilization of sorbed mercury species from solid to aqueous media, ii) the exchange of mercury between the saturated zone and the overland, and iii) the effect of the precipitation. The capability of the model to analyze the exchange of water and mercury between different subdomains will provide the basis for selecting a more efficient remediation strategy for the Y-12 complex to maximize the efficiency of the remediation project. Remediation strategies can be developed based on short-term or long-term goals. Various distinct remediation scenarios were conceptualized and simulated using the model to provide a wide range of results.

\subsection{No Remediation Simulation}

The basis of comparison was the observed discharge data and concentrations at Station 17 located EFPC. Figure 33 shows the observed discharged discharge data (cfs) and mercury concentrations $(\mathrm{mg} / \mathrm{L})$ at Station 17. 


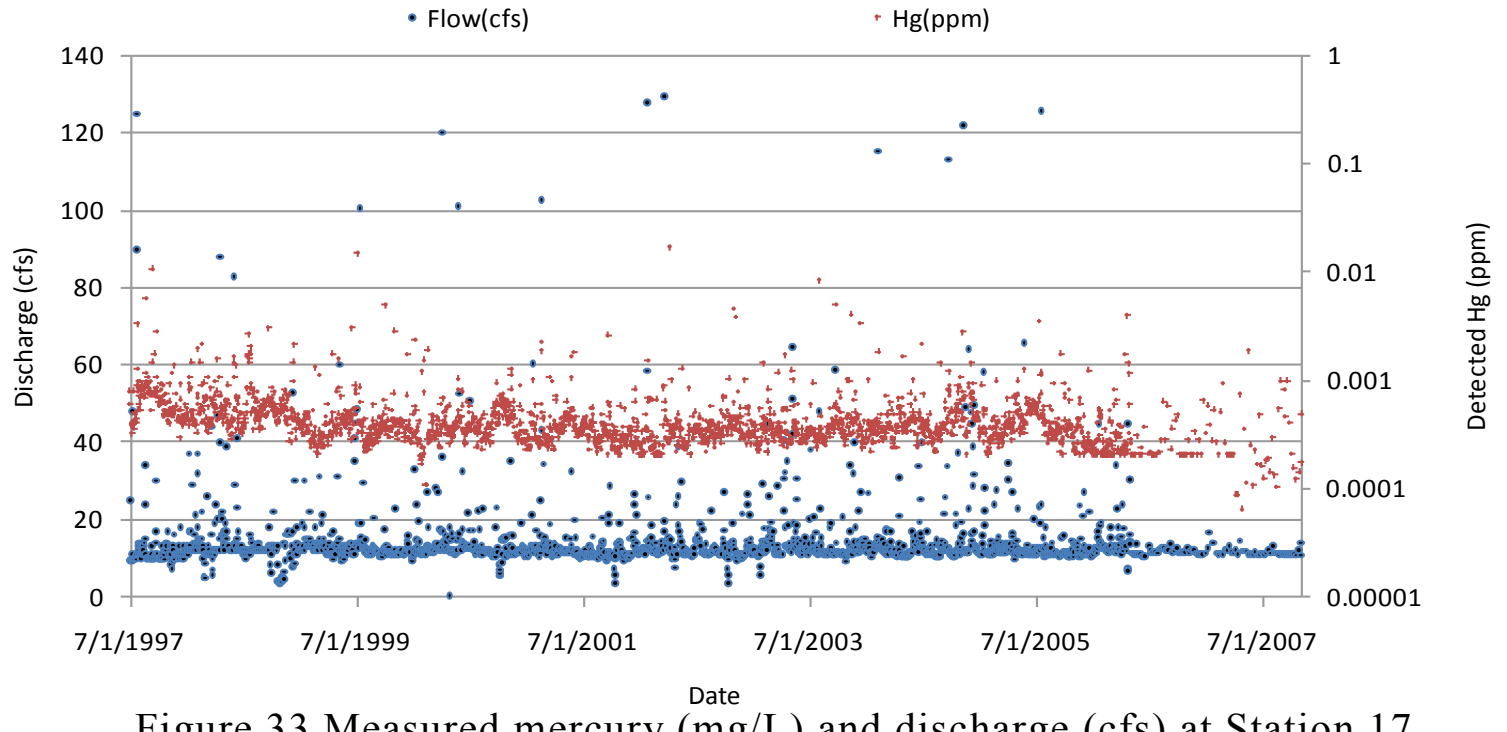

Figure 33 Measured mercury $(\mathrm{mg} / \mathrm{L})$ and discharge (cfs) at Station 17

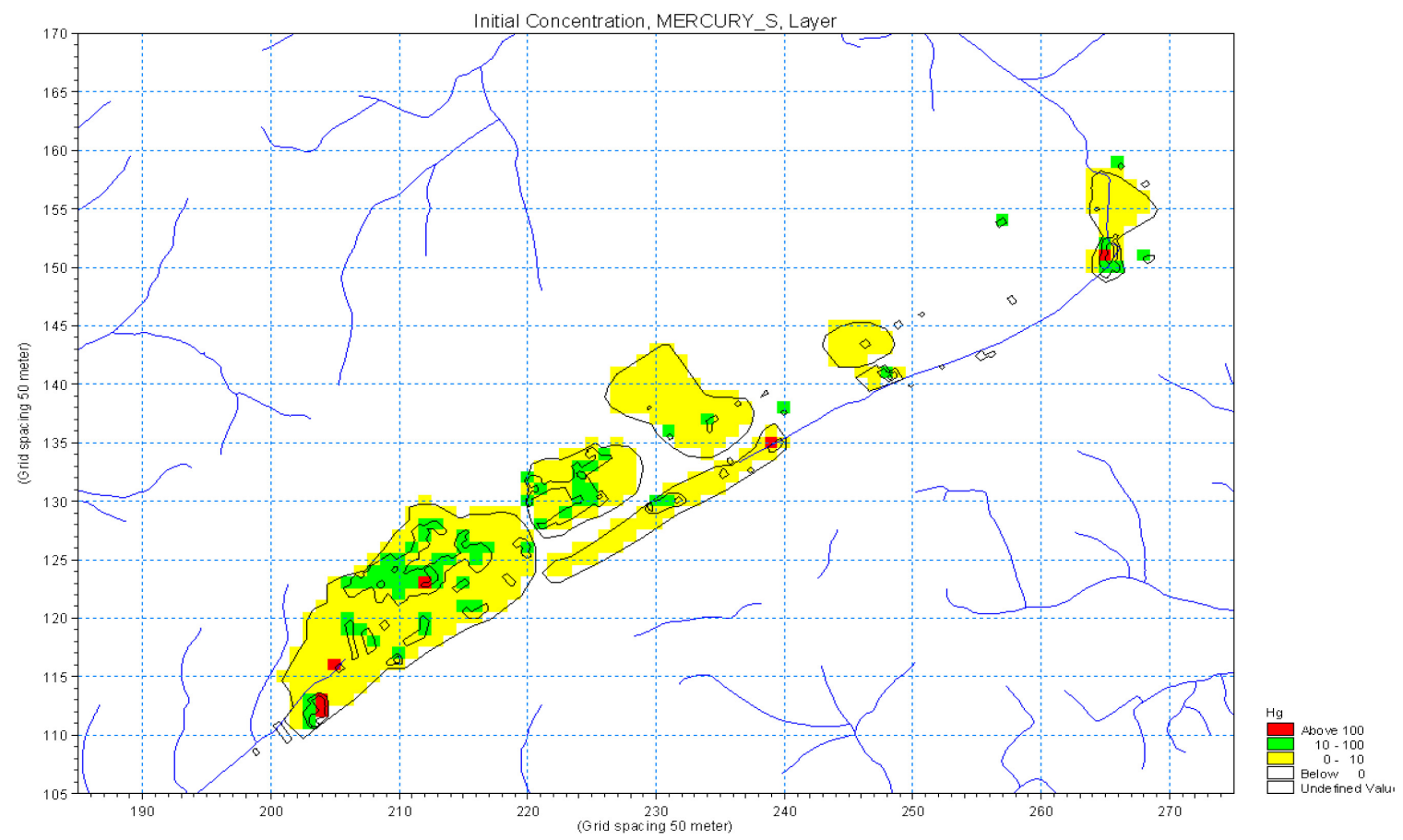

Figure 34 Initial concentrations for the no-remediation simulation

Using the soil mercury contamination map from ROD I\&II a no-remediation simulation was created to provide general characteristics of the mercury transport in the watershed. Figure 34 shows the inputs for the saturated zone at $10 \mathrm{~m}$ depth. The yellow 
indicates cells with mercury concentrations of $10 \mathrm{ppm}$, green indicates $100 \mathrm{ppm}$, and red indicates cells with 7,700 ppm.

After conducting one year of simulation, the distribution of mercury within the watershed is shown on Figure 35. Note, the blue areas represent very low concentration and demonstrate the capability of the model to couple hydrology with transport.

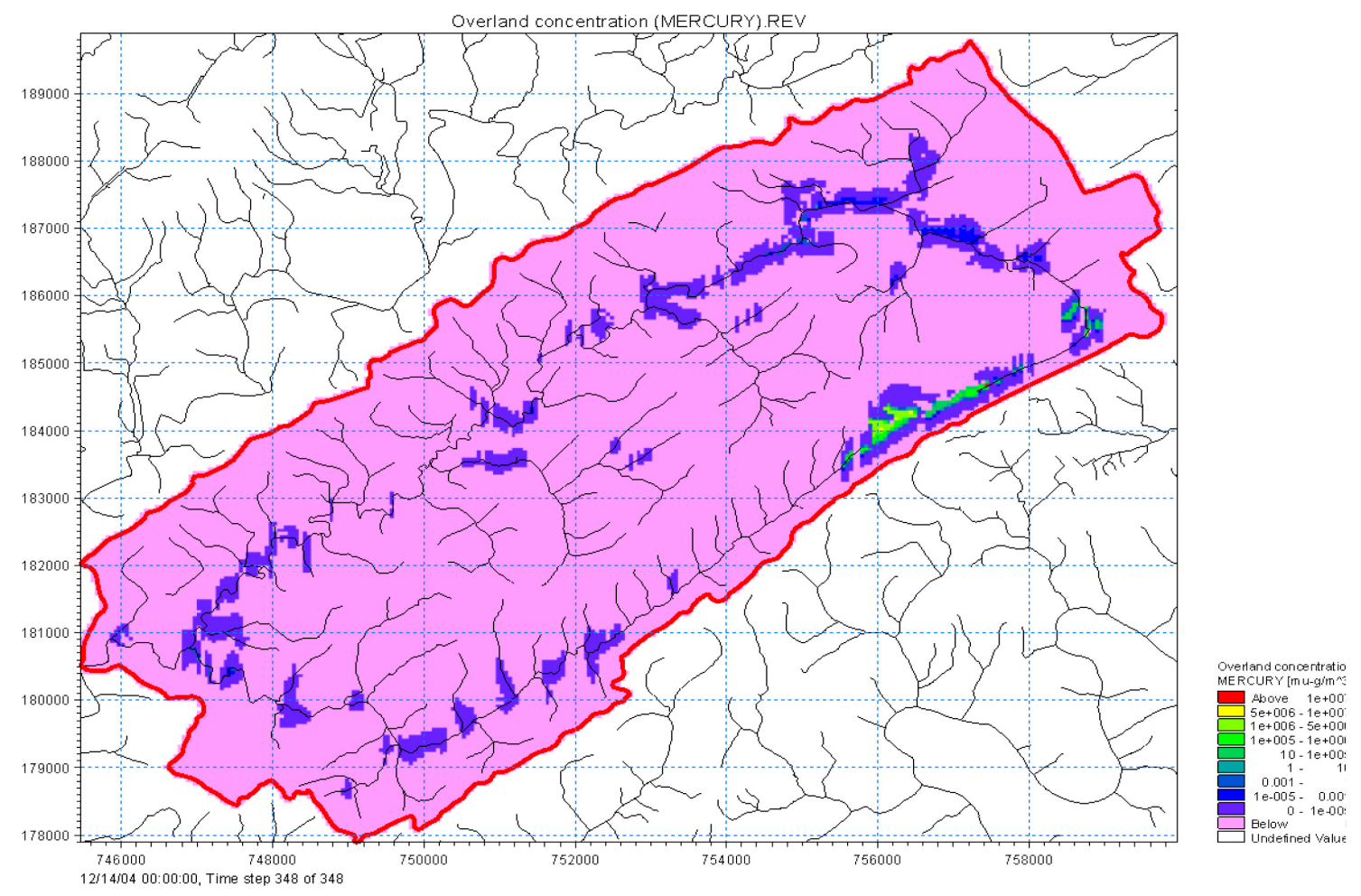

Figure 35 Simulated distribution of overland mercury transport mass per unit area 


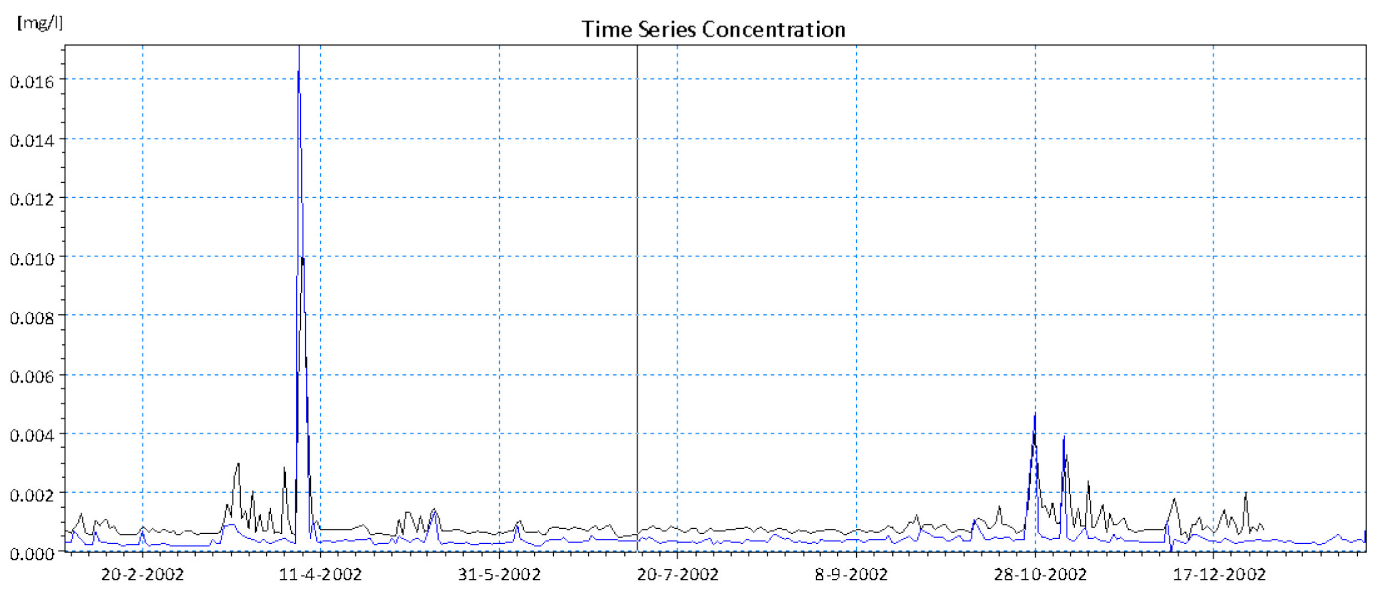

Figure 36 Observed and calculated mercury concentrations at Station 17 during year 2002

Figure 37 shows a simulation of mercury concentrations in EFPC along the seven DOE stations (shown are stations EFK 2.1, EFK 6.3, EFK 10.0, EFK 13.8, EFK 18.2, EFK 23.4, EFK 24.4). The data shows that the highest peak is observed at Station 17 (EFK 23.4) with gradual decreases downstream (caused by dilution of the tributaries).

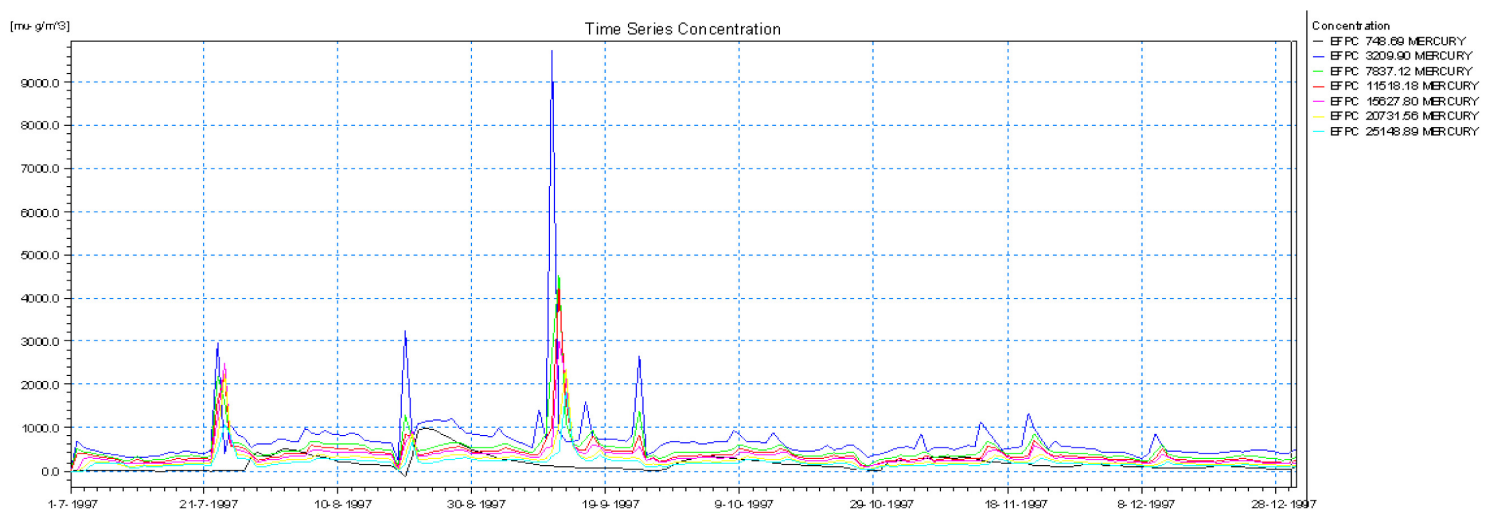

Figure 37 Calculation of $\mathrm{Hg}$ in $\mathrm{mg} / \mathrm{L}$ at various locations in EFPC

Using the initial conditions described in the previous section, the distribution of mercury was computed. Figure 35 shows the distributed overland mercury concentration on day $12 / 14 / 2004$ of the simulation. Maximum concentrations are located in the vicinity of the Y-12 complex and lower concentrations are found downstream. Traces of mercury 
$\left(>1 \mathrm{e}-005 \mu \mathrm{g} / \mathrm{m}^{3}\right)$ are found in upper reaches of tributaries, shown in purple. The model calculates the dilution effect downstream.

\subsection{Batch A Remediation Simulations}

A set of remediation scenarios, entitled Batch A, were created using the mercury concentration map shown in Figure 1. The map was converted to a grid file and strategic remediation areas were identified. In Figure 38, yellow areas indicate concentrations of $10 \mathrm{ppm}$, green indicates $100 \mathrm{ppm}$, and red indicates 7,700 ppm.
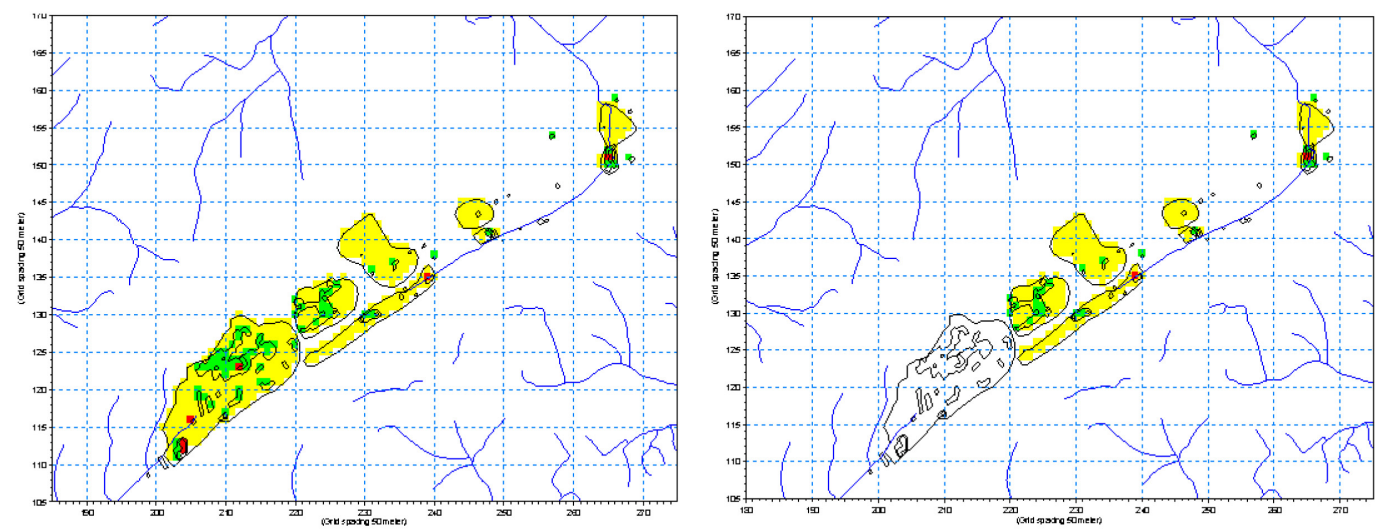

$\mathrm{A} 01$

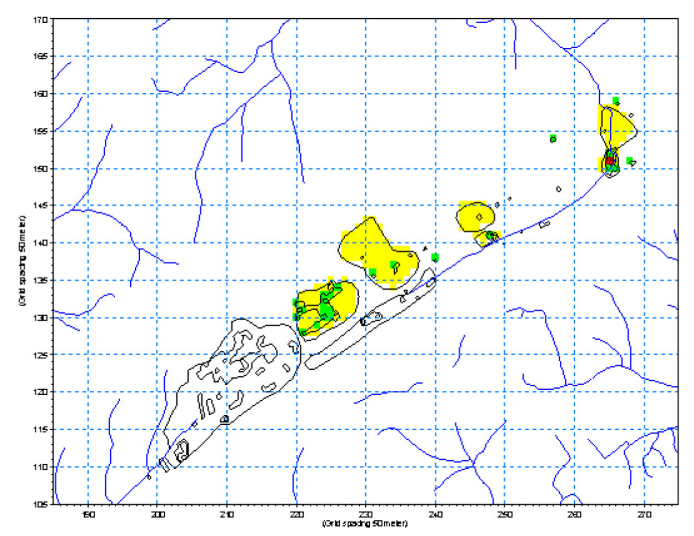

$\mathrm{A} 03$

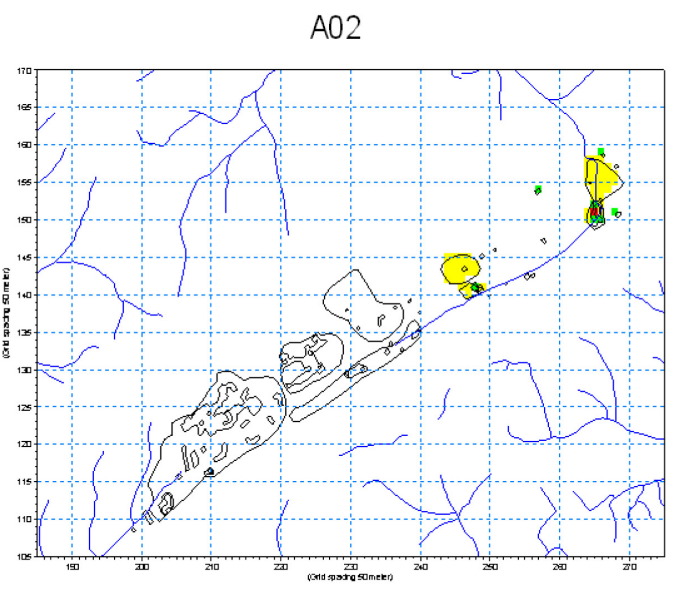

$\mathrm{A} 04$

Figure 38 Initial conditions for Batch A remediation simulations

Batch A simulations represent a phased remediation of the Y-12 complex starting from the upper reaches of EFPC. Four scenarios (including a no-remediation scenario) 
were simulated, each providing complete contaminant removal for a given treatment area as illustrated in Figure 38. Batch A remediation simulations consist of A01 (no remediation), A02 (complete remediation of large contaminant zone), A03 (A02 scenario plus complete remediation of river contaminant zone), A04 (A03 scenario plus complete remediation of upper buildings).

Results for the Batch A remediation simulations were compared for the outfall location of EFPC. Figure 39 shows the $\mathrm{Hg}$ concentrations for each scenario (A01 in red, A02 in green, A03 in blue, and A04 in pink) at the EFPC outfall (EFPC 25,485.20 m).

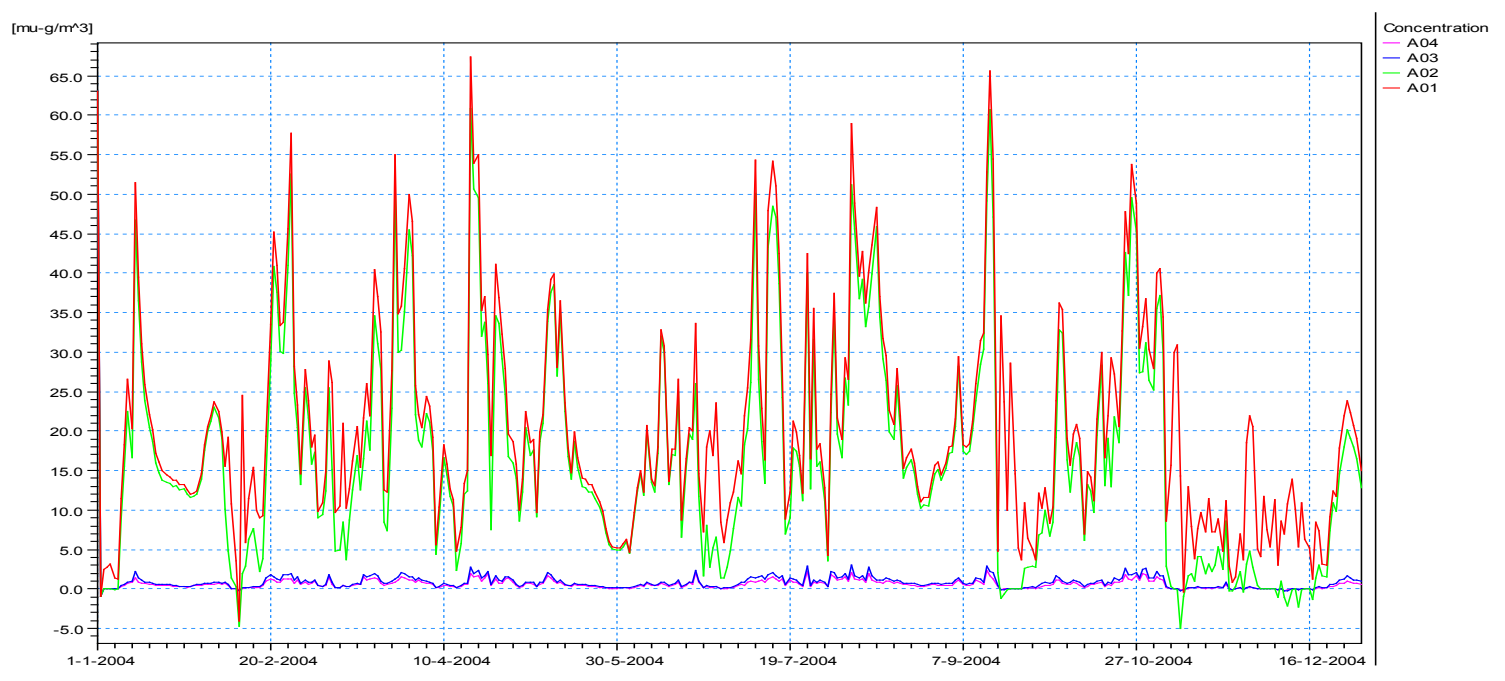

Figure $39 \mathrm{Hg}$ concentrations (mg/L) at the EFPC outfall for the Batch A simulations 


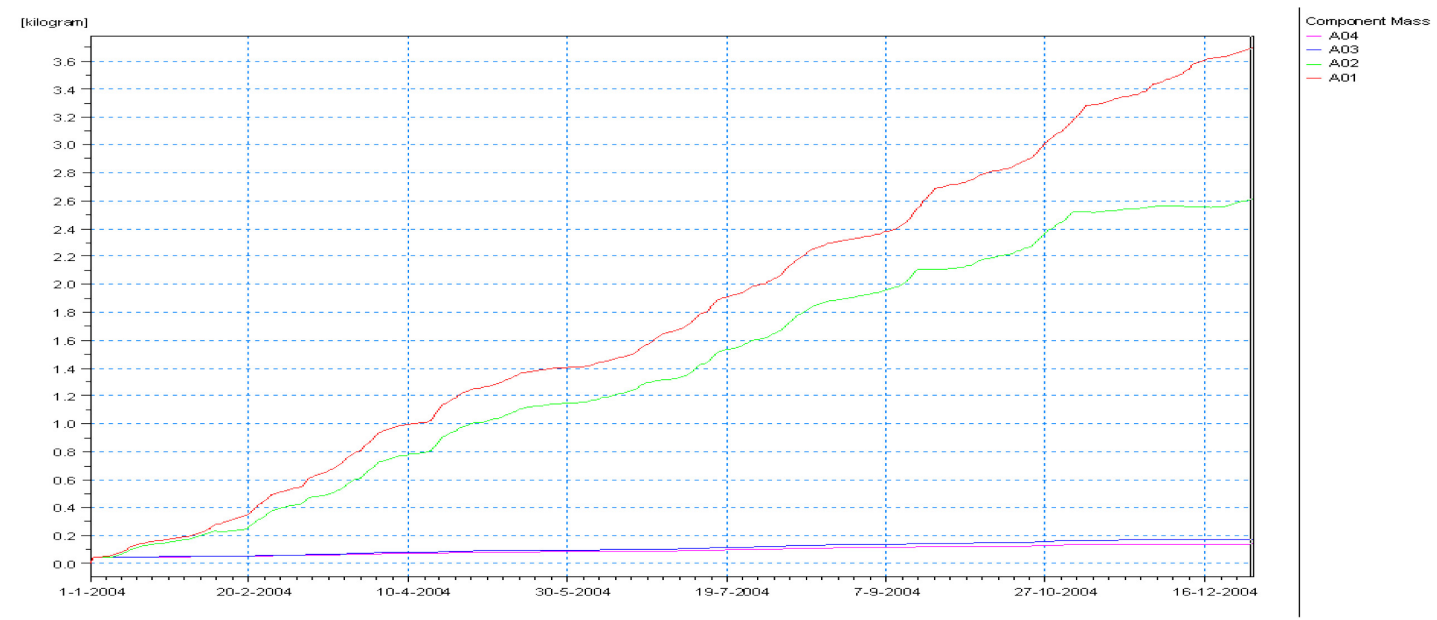

Figure $40 \mathrm{Hg}$ Accumulated Mass (kg) at the EFPC outfall for the Batch A simulations

As evident in Figure 39 and Figure 40, remediation of the larger contaminant zone in simulation A02 (green line) showed minimal Hg reduction at the EFPC outfall; however, remediation along the river (simulation A03 in blue) showed a comparatively large reduction in downstream $\mathrm{Hg}$ contamination. This is evidence that the contaminant zone, removed in $\mathrm{A} 03$, is of key importance to the reduction of $\mathrm{Hg}$ contamination in the lower reaches of EFPC and the EFPC watershed. Contamination in this zone is directly linked to water quality conditions almost $25 \mathrm{~km}$ downstream.

\subsection{Batch B Remediation Simulations}

The conclusions from the Batch A remediation simulations suggest that further simulations of remediation strategies along the river zone will provide valuable results. Batch $\mathrm{B}$ remediation simulations focus on the river contaminant zone and are also compared with the no remediation simulation. 


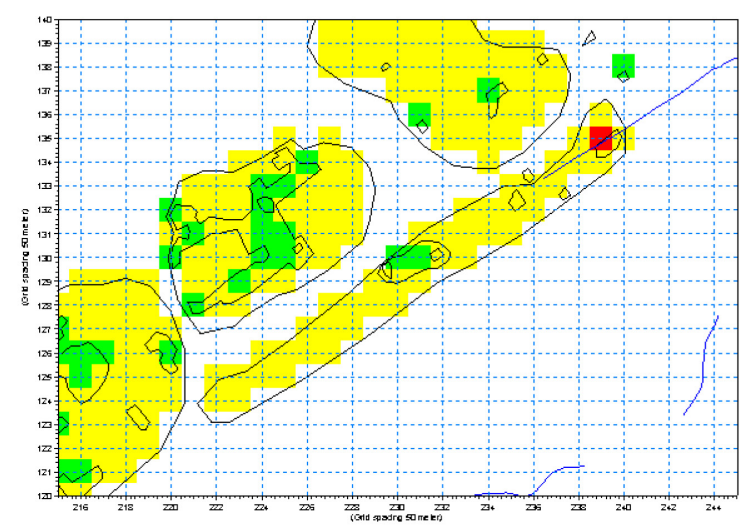

B01

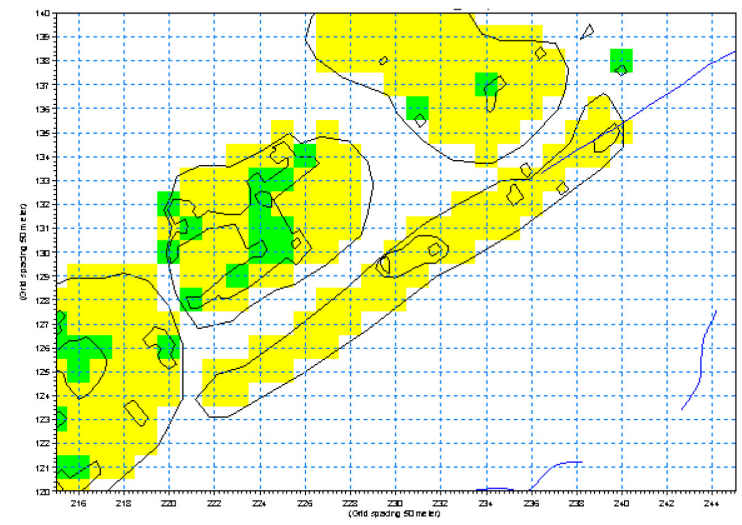

B03

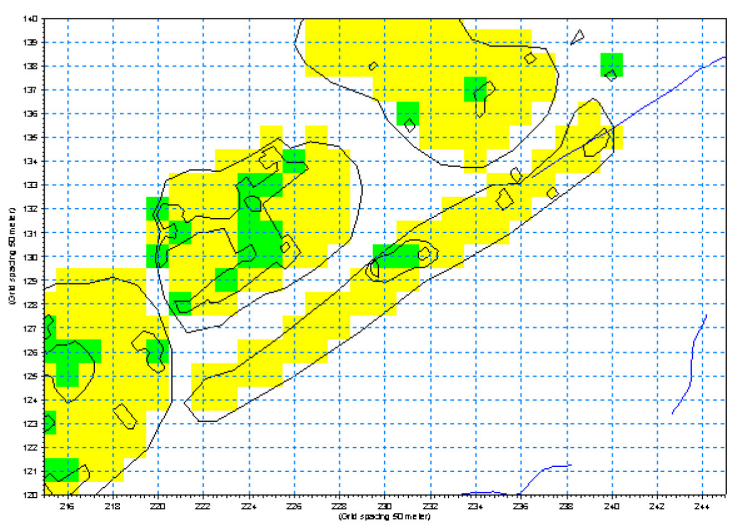

B02

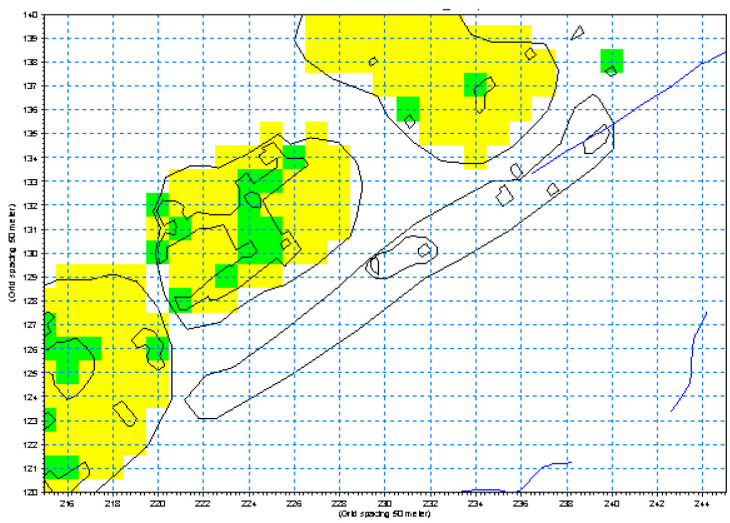

B04

Figure 41 Initial conditions for Batch B remediation simulations

Batch $\mathrm{B}$ remediation simulations focus on the reduction of contaminants from the river zone only, all other contaminant sources remain unaltered. Simulation B01 is the same no-remediation scenario presented earlier. Simulation B02 represents a reduction of the most severely contaminated grid cells $(7700 \mathrm{mg} / \mathrm{kg})$ to $10 \mathrm{mg} / \mathrm{kg}$. Simulation B03 represents a reduction of the grid cells with $100 \mathrm{mg} / \mathrm{kg}$ to $10 \mathrm{mg} / \mathrm{kg}$, so that all contamination is reduced to $10 \mathrm{mg} / \mathrm{kg}$. Finally, simulation B04 represents complete remediation of the contaminated river zone. 


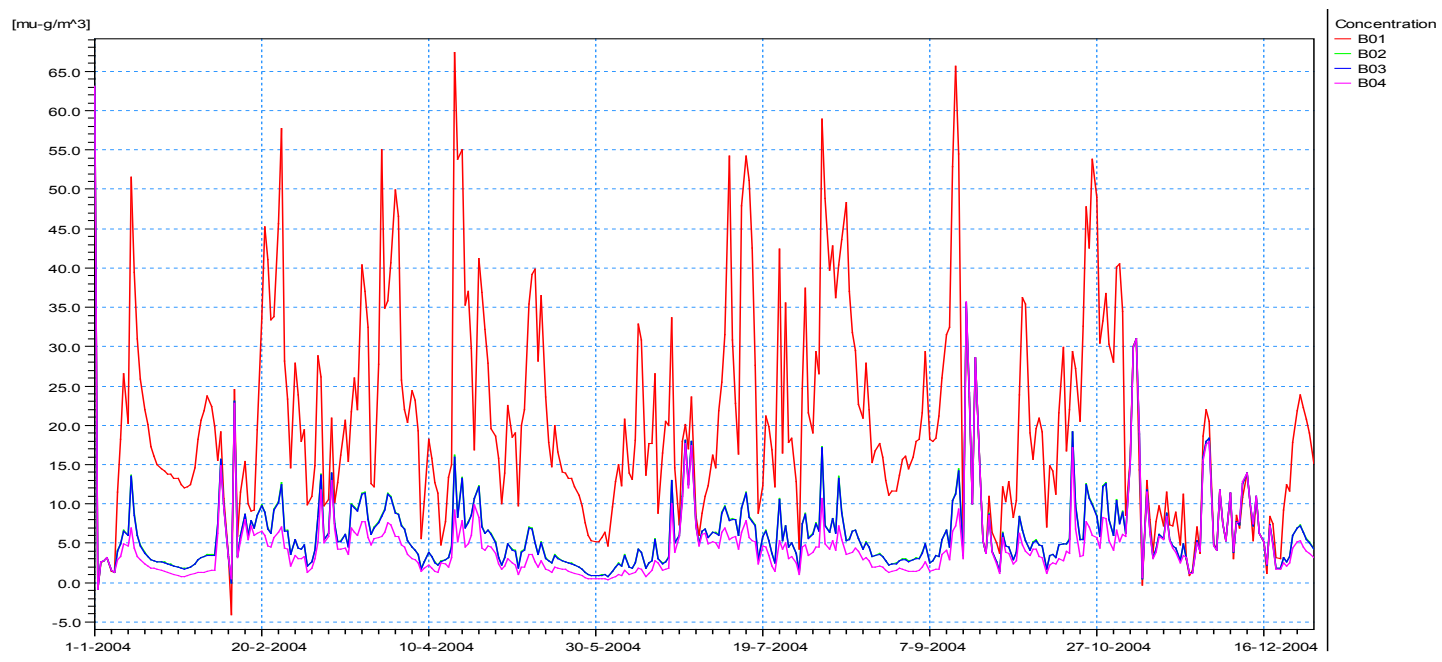

Figure $42 \mathrm{Hg}$ concentrations (mg/L) at the EFPC outfall for Batch B simulations

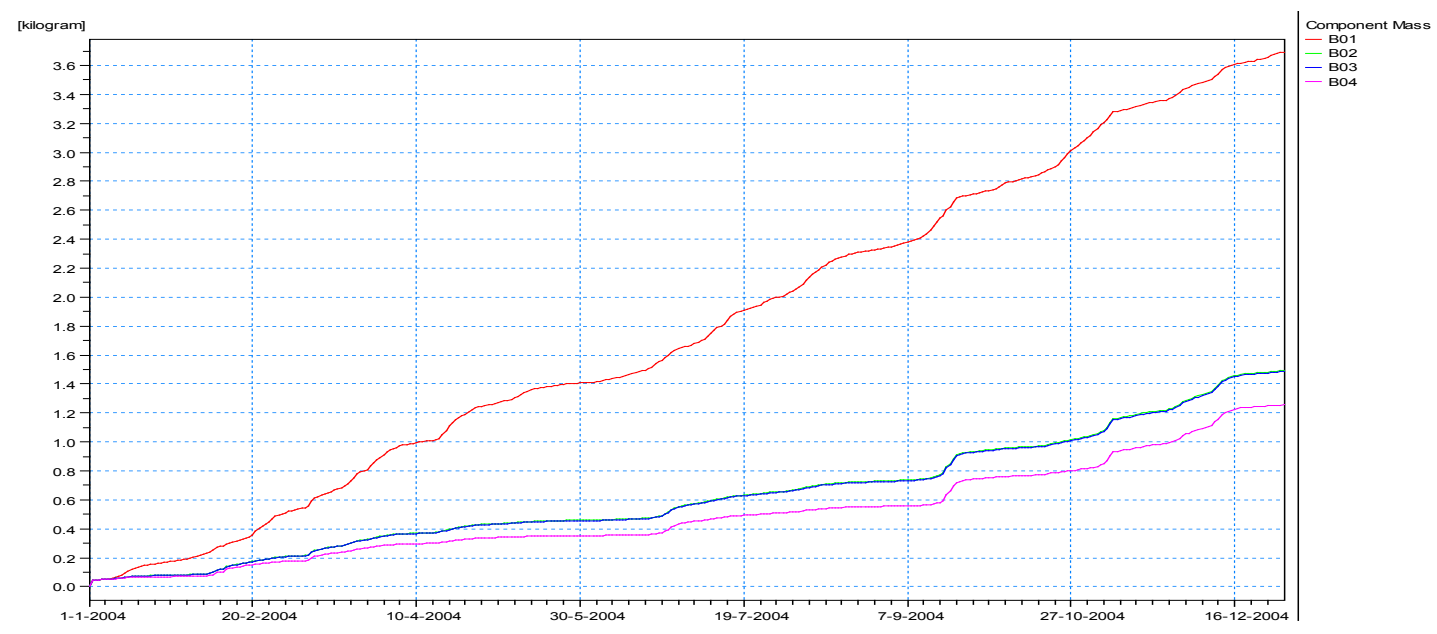

Figure $43 \mathrm{Hg}$ Accumulated Mass (kg) at the EFPC outfall for Batch B simulations

From the Batch B simulations results shown in Figure 42 and Figure 43, it is evident that reducing the contamination in the areas of high concentration (simulation B02 in green) is the most effective remediation strategy. Reducing the $100 \mathrm{mg} / \mathrm{kg}$ cells to 10 $\mathrm{mg} / \mathrm{kg}$ (simulation B03 in blue) had almost no effect on the downstream concentrations and mass accumulation. Completely eliminating the contamination in the river zone (simulation B04 in pink) had a minimal effect as well. 


\subsection{Discussion}

Batch A simulations were initially created to simulate a possible phased remediation scenario, demonstrating complete removal of contaminants for each contaminant zone. However, the simulation results showed that complete removal of contamination for some of the zones did not reduce downstream contaminant concentrations. Batch B simulations attempted to pinpoint the most effective remediation activities for a single contamination zone by simulating contaminant reduction along the river zone. Reduction of a single $7,700 \mathrm{mg} / \mathrm{kg}$ cell to $10 \mathrm{mg} / \mathrm{kg}$ provided the most dramatic reduction of downstream contamination of all the simulations, indicating that the small areas of extreme concentration affect the watershed and downstream EFPC more intensely then the large areas of low concentration. This suggests that identification and reduction of highly concentrated $\mathrm{Hg}$ sources in the $\mathrm{Y}-12$ complex (specifically along the river) is a more effective remediation strategy for the EFPC watershed than phased total zone remediation.

\subsubsection{Remediation scenario comparison}

The results of the simulations are summarized in Table 9, which shows the initial conditions for each scenario and the percent of downstream mercury reduction. By comparing the percent of simulated removal to the percent of downstream contaminant reduction, it is evident that the Batch $\mathrm{B}$ simulations are the most efficient, providing the greatest contaminant reduction with the least contaminant removal. 
Table 9 Simulation initial conditions and results

\begin{tabular}{|c|c|c|c|c|c|c|}
\hline & $\begin{array}{c}\text { Initial } \\
\text { Total Hg } \\
\text { Mass } \\
(\mathbf{k g})\end{array}$ & $\begin{array}{c}\text { Mass } \\
\text { from red } \\
\text { cells (kg) }\end{array}$ & $\begin{array}{c}\text { Mass from } \\
\text { green cells } \\
(\mathrm{kg})\end{array}$ & $\begin{array}{c}\text { Mass from } \\
\text { yellow cells } \\
(\mathrm{kg})\end{array}$ & $\begin{array}{c}\text { Scenario } \\
\text { Removal }\end{array}$ & $\begin{array}{c}\text { Downstream } \\
\text { Hg } \\
\text { Reduction }\end{array}$ \\
\hline Batch A & \multicolumn{7}{|l|}{} \\
\hline A01 & 2383825 & 1963500 & 280500 & 139825 & $0.00 \%$ & $0.00 \%$ \\
\hline A02 & 837675 & 654500 & 106250 & 76925 & $64.86 \%$ & $29.26 \%$ \\
\hline A03 & 484925 & 327250 & 97750 & 59925 & $79.66 \%$ & $95.27 \%$ \\
\hline A04 & 376975 & 327250 & 29750 & 19975 & $84.19 \%$ & $96.20 \%$ \\
\hline Batch B & \multicolumn{7}{|l|}{} \\
\hline B01 & 2383825 & 1963500 & 280500 & 139825 & $0.00 \%$ & $0.00 \%$ \\
\hline B02 & 2057000 & 1636250 & 280500 & 140250 & $13.71 \%$ & $59.55 \%$ \\
\hline B03 & 2049350 & 1636250 & 272000 & 141100 & $14.03 \%$ & $59.77 \%$ \\
\hline B04 & 2031075 & 1636250 & 272000 & 122825 & $14.80 \%$ & $66.00 \%$ \\
\hline \multicolumn{7}{|l|}{} \\
\hline Final & 422875 & 0 & 280500 & 142375 & $82.26 \%$ & $83.15 \%$ \\
\hline
\end{tabular}

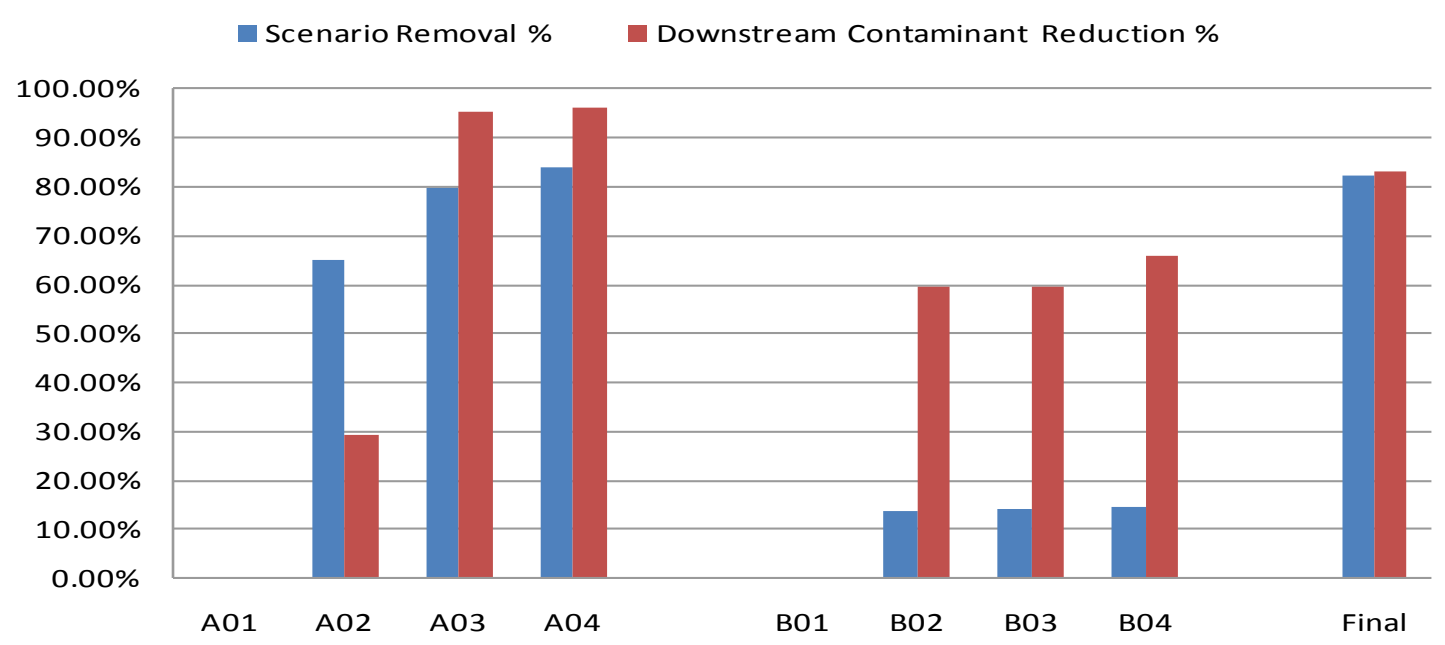

Figure 44 Comparison of percent removal and percent reduction

The results are also illustrated in Figure 44 which compares the percent scenario removal with the percent downstream contaminant reduction for each simulation. While 
all the Batch B simulations demonstrate high efficiency, simulation B02 requires the least amount of soil removal because only one $40 \mathrm{~m}$ by $40 \mathrm{~m}$ cell is removed.

\subsubsection{Mercury transport timeseries}

The model generated a set of more than 35 timeseries for each simulation, documenting the movement of mercury through the hydrologic zones of EFPC watershed for the simulation period. Timeseries include storage in saturated zone, unsaturated zone, and overland zone as well as exchange of mercury between the zones. The SZ Storage Rate is the rate of change of storage of mercury in the saturated zone. The saturated zone is a crucial hydrologic zone in the model as it is where the mercury is loaded initially. As seen in Figure 45 and Figure 47, the SZ experiences a reduction of mercury (or negative rate of change) throughout most of the year, until storage in other hydrologic zones increases and begins to exchange back to the SZ. The rate of change of storage of mercury for all three hydrologic zones tends to coincide with the precipitation for 2004, demonstrating peaks in February, June, September, and November.

Selected data was used Figure 46 and Figure 48 to illustrate the rates of exchange between different hydrologic zones; the saturated zone to river, the saturated zone to overland, and the overland to river. The exchange between the saturated zone and unsaturated zone is not shown; it tends to spike during heavy rains and remain unchanged during moderate to low precipitation. The SZ Drain -> River is reduced in the Batch A scenarios after removing the entire contamination zone along the river, but is largely unchanged in the Batch B scenarios. This is likely due to the fact that while the contamination is reduced in the $\mathrm{B} 02$ simulation, the area of contamination remains the same and continues to exchange with the river at the same rate. 


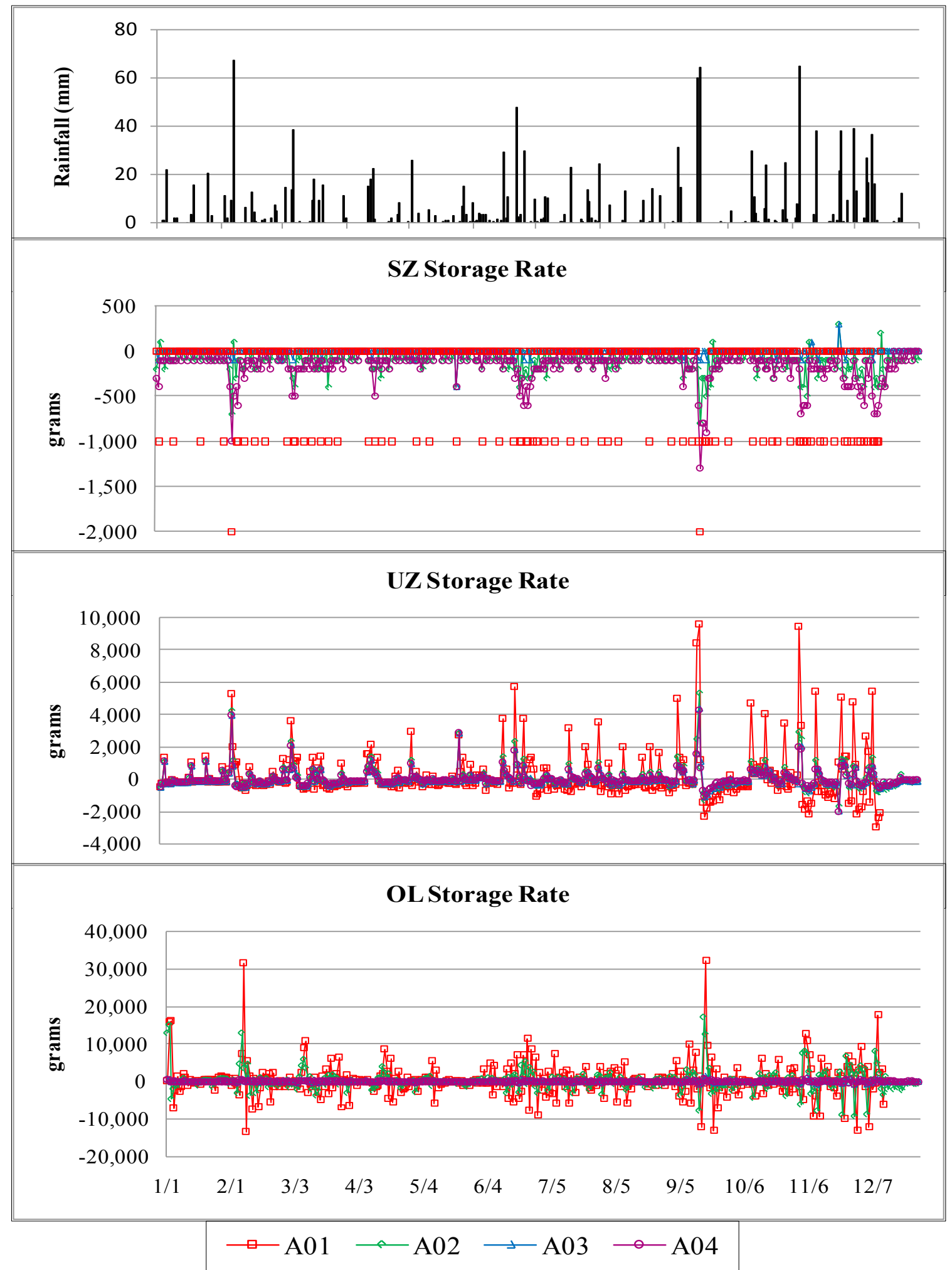

Figure 45 Mercury storage rates in SZ, UZ, and OL zone for Batch A simulations 


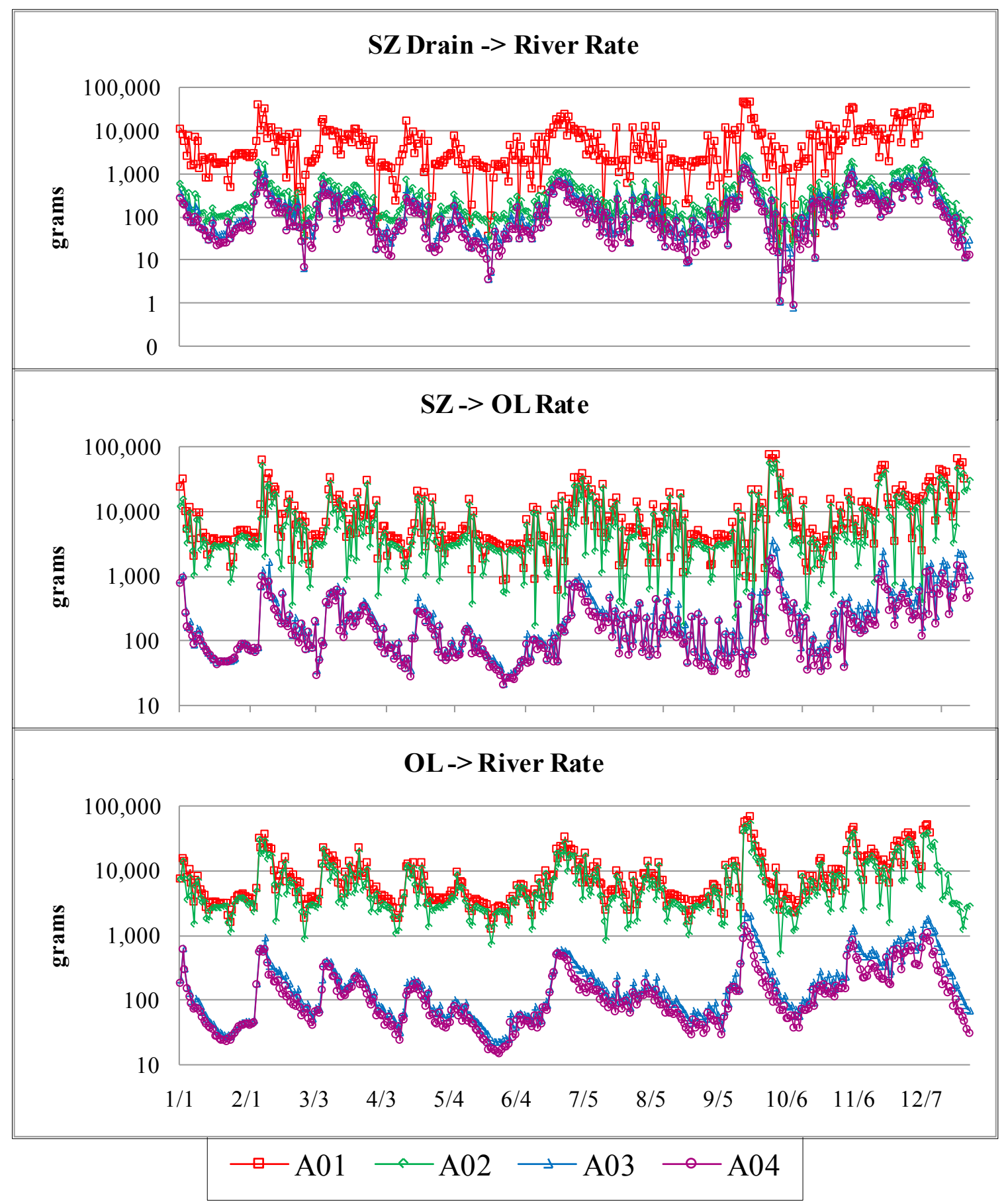

Figure 46 Exchange rates between hydrologic zones for Batch A simulations 


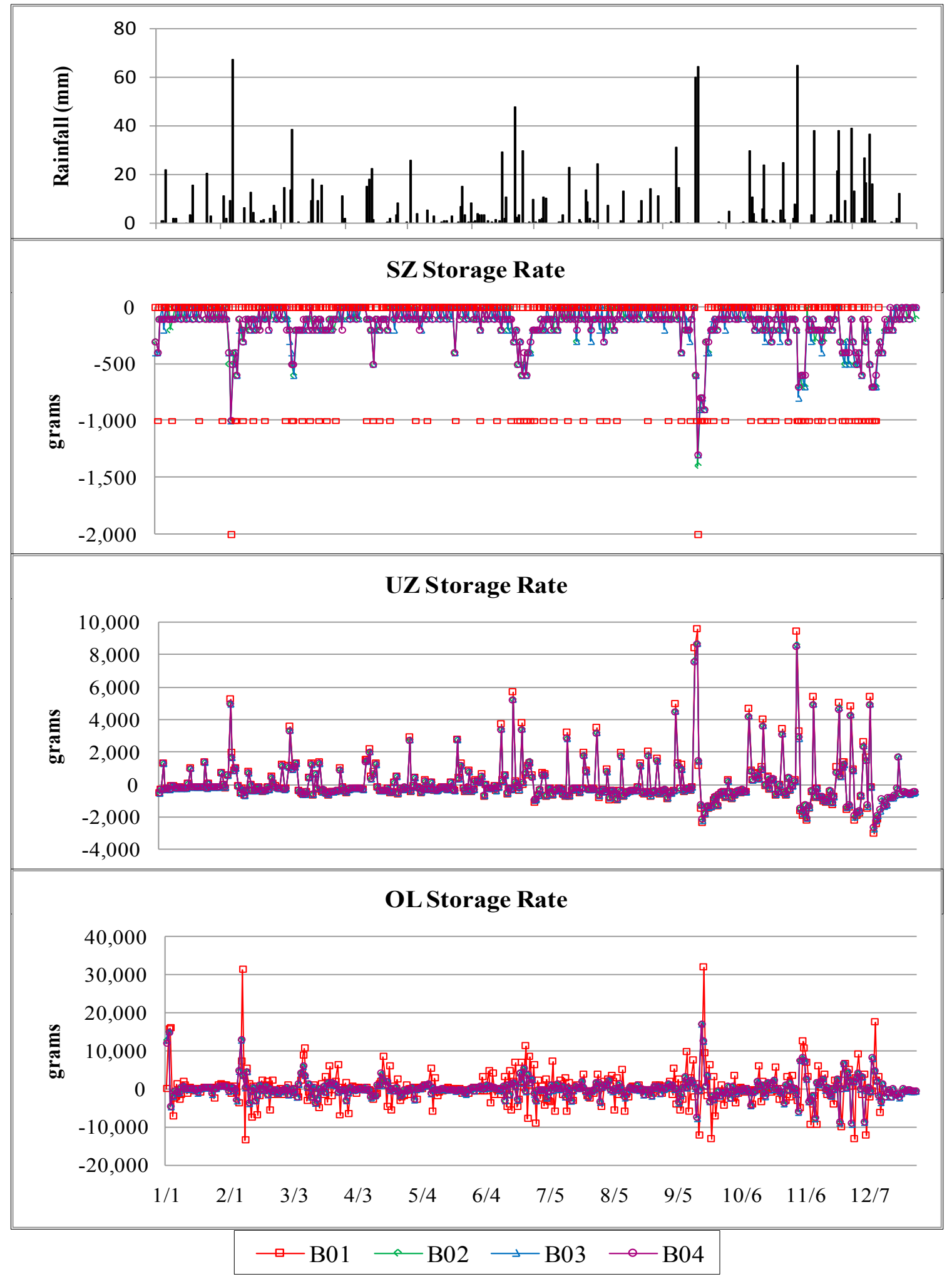

Figure 47 Mercury storage rates in SZ, UZ, and OL zone for Batch B simulations 


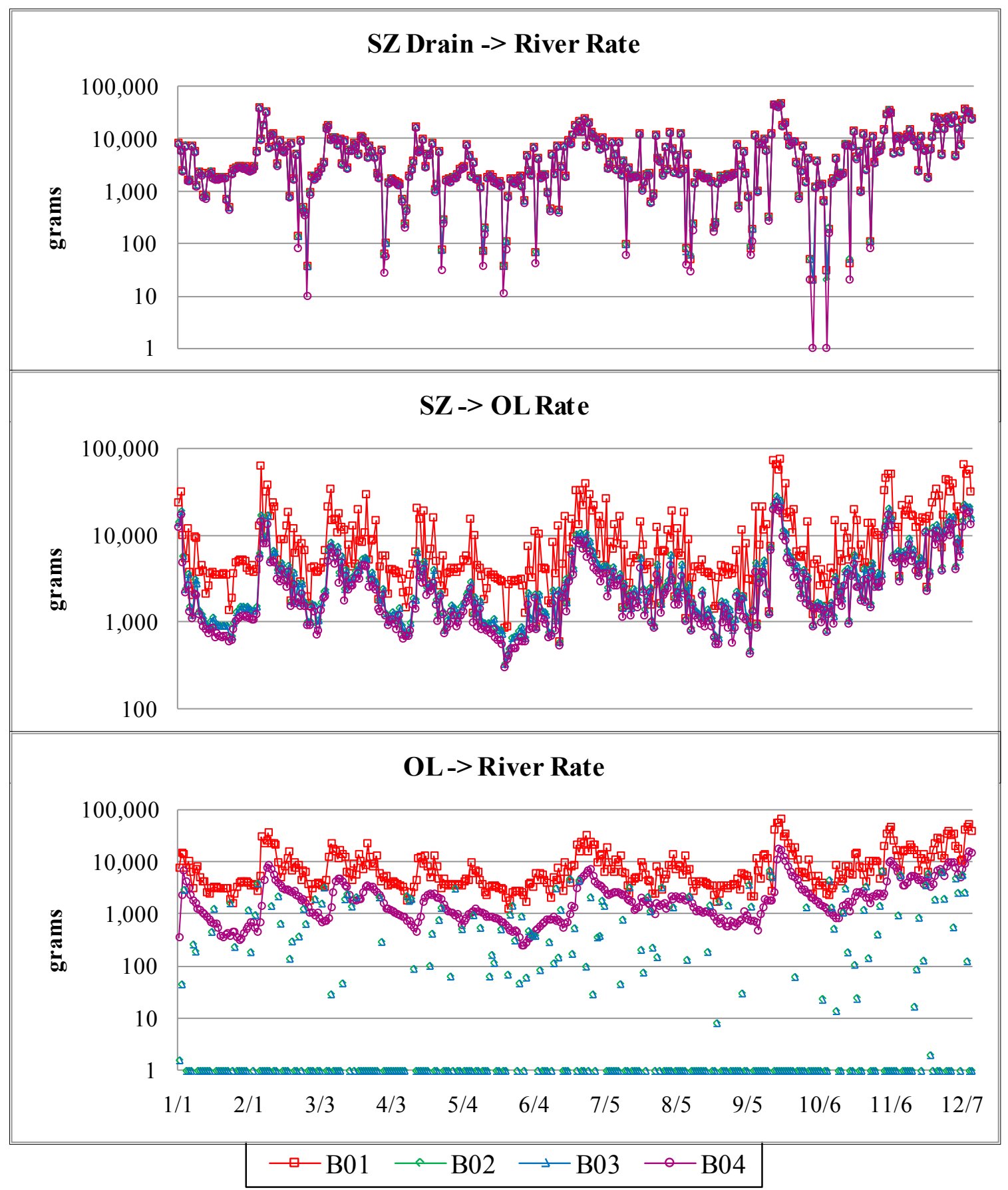

Figure 48 Exchange rates between hydrologic zones for Batch B simulations

\subsubsection{Effect of rainfall}

The rainfall data for all of the simulations plays an important role in the exchange of mercury. Rainfall affects the exchange of mercury by facilitating its movement through 
the hydrologic zones. To visualize how the rainfall affects the transport of mercury, two of the peak rainfall months in 2004 were selected and compared with the input rates to the saturated and unsaturated zones as shown in Figure 49 and Figure 50. The rate of input of mercury to the saturated zone tends to follow after precipitation events by 24 to 48 hours, as shown in Figure 49 where the blue bars are rainfall in millimeters and the red bars are mercury in kilograms. In addition, mercury continues to transfer for over a week after the heavy precipitation event on September $16^{\text {th }}$ and $17^{\text {th }}$. This trailing effect indicates the drainage and transport parameters associated with the system when confronted with complete saturation from a precipitation event.

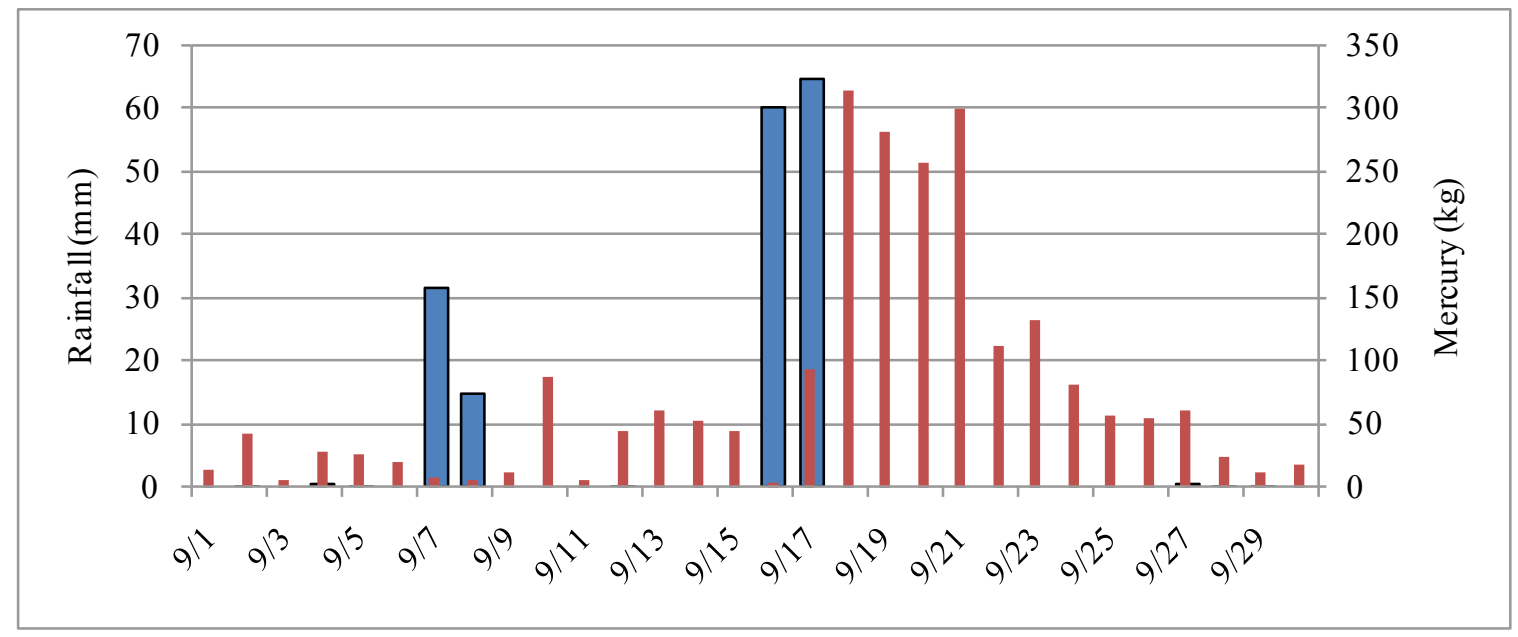

Figure 49 The affect of rainfall on mercury transport to the SZ for September Mercury transport to the unsaturated zone tends to be more sensitive to rainfall. Figure 50 shows the rate of input of mercury to the unsaturated zone in red. The inputs to the UZ directly correspond to rainfall; however, in the case of heavy precipitation events, mercury continues to exchange for a few days after the event. 


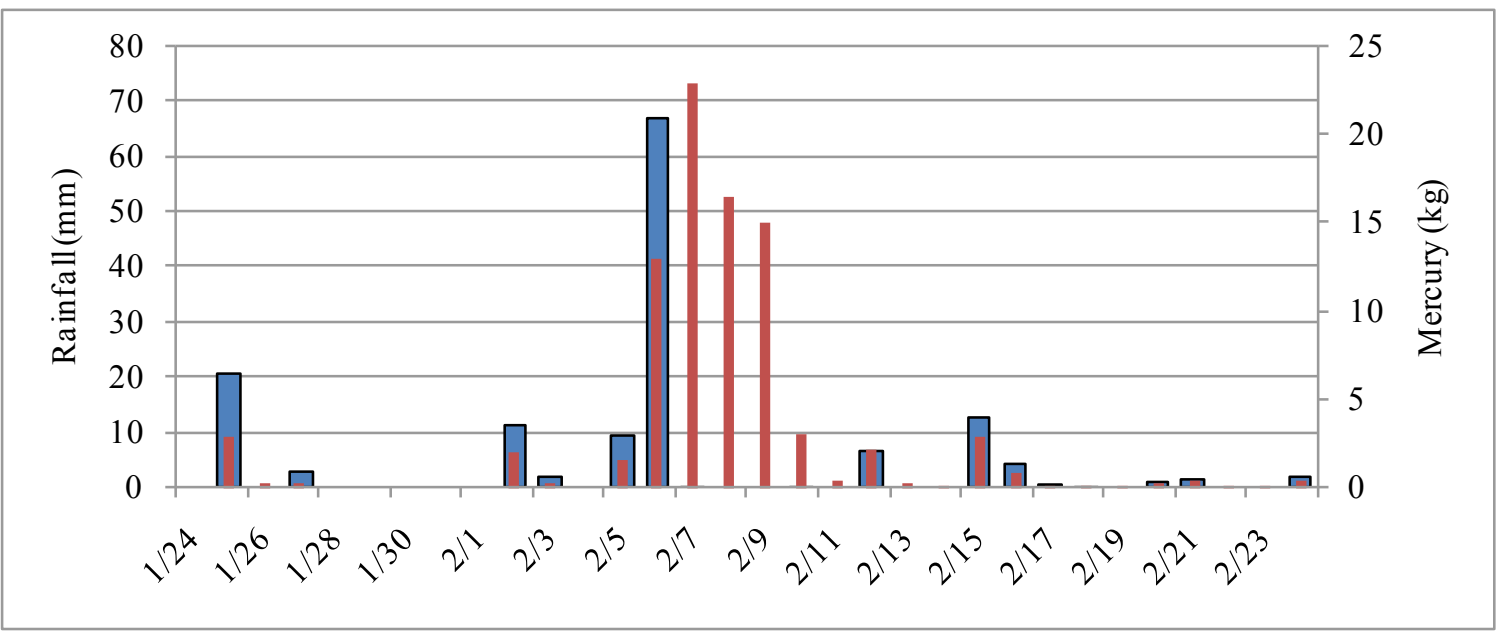

Figure 50 The affect of rainfall on mercury transport to the UZ for February

\section{CONCLUSIONS}

The environment in the vicinity of the Y-12 Plant in East Fork Poplar Creek watershed at the Oak Ridge Reservation (ORR) has been contaminated by mercury as a result of thermonuclear processing activities. To comply with the regulatory standards of mercury concentrations in streams and total maximum daily loads, a significant reduction of the mercury levels will be required, particularly in the natural waters, with target levels in the low parts per trillion. The hydrology of the East Fork Poplar Creek watershed has been analyzed using MIKE SHE/MIKE 11 software, which is an integrated surface and subsurface finite difference model. The model integrates the main components of a hydrological cycle, and includes groundwater flow (3D saturated and unsaturated), overland flow, flow in rivers and evapotranspiration.

The model simulates one-dimensional flow within the river; once the flow rate exceeds the corresponding conveyance capacity, the rivers flood and the software applies a two-dimensional simulation to compute the flow stages and rates. The objective was to analyze the mercury cycle in the environment and to determine the transport of 
contamination within the watershed. The integrated modeling of river, surface and groundwater provides understanding of the mechanisms of mercury transport within the watershed.

An integrated surface and groundwater flow model has been developed which incorporates the entire hydrological cycle: precipitation, evapotranspiration, overland and river flow, and flow in the groundwater saturated and unsaturated zones. The model includes a transport component which uses advection, dispersion, sorption/desorption to provide high resolution information about water and contaminant fluxes between various hydrologic components. The objective of the numerical models was to provide an improved understanding of the transport of mercury in saturated and variably saturated zones, and transport of mercury within the EFPC watershed under various remediation scenarios and evaluate the impact of remediation alternatives on water and mercury interaction within the hydrologic domains (streamflow, overland flow, vadoze zone and saturated flow).

The remediation scenarios focused on determining the optimal source control strategy that will ensure minimum excavation and treatment of contaminated soil with greatest reduction of downstream loading at Station 17. Scenarios included total plume removal, which involves extensive soil removal (Batch A), and source control, which involves sump contaminant reduction (Batch B). Removal of contamination along key stormflow zones proved highly effective at reducing downstream concentrations. However, the most effective strategy was to remove the small areas with high levels of contamination, i.e. capture zones and stormflow sumps within the Y-12 Complex. This strategy provides immediate 6-fold reduction of mercury contamination in downstream EFPC with the least 
amount of soil removal. Remediation activities, including soil removal, in a contaminated area may mobilize pollutants into the river. Therefore, strategies which do not require extensive earthwork are more environmentally safe, as well as more cost-efficient. The results from these simulations support the research hypothesis in that the most efficient remediation strategy, evaluated in this paper, was the removal of areas of high contamination or hot spots rather than the wide-scale treatment of contaminated groundwater.

Retardation factor has significant impact on remedial actions related to soil excavation, effecting the exchange of mercury between saturated, unsaturated and river subdomains. Retardation factor is defined as the ratio of the groundwater velocity to the retarded solute velocity which is expressed as, $\mathrm{Rf}=1+\frac{\rho_{\mathrm{b}} \mathrm{K}_{\mathrm{d}}}{\theta}$. Where the Kd value is the linear equilibrium between aqueous and soil concentration. The large retardation factor for mercury in ORR soil shows that the solute velocity is about 1,900 times smaller than the groundwater velocity Therefore, source removal in the vicinity of stream has greatest effect on exchange of river with subsurface domain.

The reduction of a single, highly-contaminated cell along the river in the Y-12 complex was the most efficient remediation scenario analyzed (as proved with simulation B02). This cell corresponds with the beginning of the North/South Pipe in the Y-12 complex, the outfall of the pipe is defined as the headwaters of EFPC by the Tennessee Department of Environment and Conservation (TDEC) (Hollerman et al., 1999). This is a key remediation area, as contamination from historical mercury spill zones in Y-12 are drained to the North/South Pipe. Based on the results from the simulations, it is 
recommended that future short-term, mercury remediation strategies focus on this single area to achieve immediate reduction of mercury contamination throughout the EFPC watershed.

The results from this work illustrate that a more effective cleanup effort of mercury contaminated streams, soil and groundwater at Y-12 National Security Complex will be achieved by analyzing the relative impact of selected remediation scenarios on water and mercury fluxes across the model domain.

\section{DISCLAIMER:}

All data used in this work was obtained from publically available sources. 


\section{REFERENCES}

Aastrup, M, Johnson, J., Bringmark, E., Bringmark, I and A. Iverfeldt. 1991. Occurrence and transport of mercury within a small catchment area. Water, Air, and Soil Pollution 56, 155-167.

Abbott M. B. and J. C. Refsgaard. 1996. Distributed Hydrological Modeling. Kluwer Academic: Dordrecht.

Akçay, H., Kilin, S. and C. Karapire. 1996. A comparative study on the sorption and desorption of $\mathrm{Hg}$, $\mathrm{Th}$ and $\mathrm{U}$ on clay. Journal of Radioanalytical and Nuclear Chemistry. V. 214, N. 1, 51-66.

Allison J, D. and T. L. Allison. 2005. Partition coefficient for metals in surface water, soil, and Waste. EPA/600/R-05/074.

Ambrose, R. \& Wool, T. Modeling Tools Used for Mercury TMDLs in Georgia Rivers. Proceedings of the 2001 Georgia Water Resources Conference, March 26-27, 2001, at the University of Georgia. Kathryn. J. Hatcher, editor, Institute of Ecology, The University of Georgia, Athens, Georgia.

Anderson, James R, Ernest E. Hardy, John T. Roach, Richard E. Witmer. 1976. A Land Use and Land Cover Classification System for Use with Remote Sensor Data. USGS Circular 671.

ATSDR (Agency for Toxic Substances and Disease Registry), Federal Facilities Assessment Branch and Division of Health Assessment and Consultation. 2006. Public Health Assessment: Evaluation of Potential Exposures to Contaminated Off-Site Groundwater from the Oak Ridge Reservation (USDOE) Oak Ridge, Tennessee.

Basic Concepts of Open Channel Flow Measurement. US EPA. 2004. Available from URL: http://www.epa.gov/ORD/NRMRL/Pubs/600R01043/600R01043chap2.pdf

Bectel Jacobs Company LLC. 2009. 2009 Remediation Effectiveness Report for the US Department of Energy, Oak Ridge Reservation, Oak Ridge, Tennessee.

Bibler, J. P. and D. B. Marson. 1992. Behavior of mercury, lead, cesium, and uranium ions on four SRS soils. Report WSRC-RP-92-326, p.50. Available at http://www.osti.gov/bridge/servlets/purl/7064035-hwmdrD/7064035.pdf.

Carsel, R. F. and R. S. Parrish. 1988. Developing Joint Probability Distributions of Soil Water Retention Characteristics. Water Resources Research, V. 24, N. 5, P 755769. 
ChemRisk. (1999a). Radionuclide releases to the Clinch River from White Oak Creek on the Oak Ridge Reservation - an assessment of historical quantities released, offsite radiation doses, and health risks, task 4 . Reports of the Oak Ridge dose reconstruction, volume 4. Tennessee Department of Health. July 1999. Available from URL: http://www2.state.tn.us/health/CEDS/OakRidge/WOak1.pdf.

ChemRisk. 1999b. Screening-level evaluation of additional potential materials of concern, task 7. Reports of the Oak Ridge dose reconstruction, volume 6. Tennessee Department of Health. July 1999. Available at URL: http://www2.state.tn.us/health/CEDS/OakRidge/Screen.pdf

Chow, V.T., 1959. Open-Channel Hydraulics. McGraw-Hill, New York, NY.

Clapp, R., and G. Hornberger. 1978. Empirical Equations for Some Soil Hydraulic Properties, Water Resour. Res., 14(4), 601-604.

Danish Hydraulic Institute (DHI). 2008. MIKE 11 Short Descriptions. Hørsholm: Danish Hydraulic Institute.

Danish Hydraulic Institute (DHI). 2008. MIKE SHE Reference Manual. Hørsholm: Danish Hydraulic Institute.

Danish Hydraulic Institute (DHI). 2008. MIKE SHE Reference Manual. Hørsholm: Danish Hydraulic Institute.

EPA. 2008. Proposed Total Maximum Daily Load (TMDL) for Mercury in East Fork Poplar Creek Lower Clinch River Watershed (HUC 0601 0207) Anderson and Roane Counties, Tennessee, Preliminary 2nd Draft, October 2008.

EPA. 2008. Total Maximum Daily Load (TMDL) Modeling Toolbox, http://www.epa.gov/athens/wwqtsc/html/tools.html. Accessed October 2008.

Fröberg, M., Jardine, P. M., Hanson, P. J., Swanston, C. W., Todd, D. E., Tarver J. R., and C. T. Garten, Jr. 2007. Low Dissolved Organic Carbon Input from Fresh Litter to Deep Mineral Soils. Soil Sci Soc Am J., 71, p. 347-354.

Glass, G. E, Sorenson, J. A., Schmidt, K. W. and G.R. Rapp. 1990. New source identification of mercury contamination in the Great Lakes, Environmental Science and Technology, 24 (7), 1059-1069.

Graham, D.N. and M.B. Butts, 2005. Flexible, integrated watershed modeling with MIKE SHE. Singh, V.P., Frevert, D.K. (Eds.), Watershed Models, pp. 245-272, CRC Press. 
Han, Fengxiang X, Yi Su, David L Monts, Charles A Waggoner, M John Plodinec. 2006. Binding, distribution, and plant uptake of mercury in a soil from Oak Ridge, Tennessee, USA.

Hardeman, William D. Geologic Map of Tennessee. Tennessee Division of Geology, Published by the Tennessee Division of Geology, 1966, at a scale of 1:250,000.

Hatcher, R. D. et al. 1989. Field Guide and Perspective on the Geology and Hydrology of the Oak Ridge Reservation. Oak Ridge National Laboratory/University of Tennessee, Oak Ridge, Tennessee.

Hatcher, R. D., Lemiszki, P. J., Dreier, R. B., Ketelle, R. H., Lee, R. R., Leitzke, D. A., McMaster, W. M., Foreman, J. L., and S. Y. Lee. 1992. Status Report on the Geology of the Oak Ridge Reservation, ORNL/TM-12074. Prepared for the Office of Environmental Restoration and Waste Management.

Hollerman, W. et al. 1999. Results from the low level mercury sorbent test at Oak Ridge Y-12 Plant in Tennessee. Journal of Hazardous Materials B68, p. 193-203.

Hornberger, G. M., J. P. Raffensperger, P. L. Wiberg, K. N. Eshelman, 1998: Elements of Physical Hydrology, Johns Hopkins University Press, Baltimore, pp.302.DHI, 2008. MIKE SHE User Manual, Danish Hydraulic Institute, Hørsholm, Denmark.

Kaplan, D. I. Knox, S. and J. Myers. 2002. Mercury Geochemistry in a Wetland and its Implications for In-situ Remediation Available from URL: http://sti.srs.gov/fulltext/ms2002056/ms2002056.html

Kaplan, D. I., and G. M. Iversen. 1999. Material and Methods for the Ford Building Sediment Hg-Kd Study. Report WSRC-TR-99-00357 prepared for DOE under the contract number DE-AC09-96SR18500.

Kaplan, D. I., and S. M. Serkiz. 2000. In-situ Kd Values and Geochemical Behavior for Inorganic and Organic Constituents of Concern at the TNX Outfall Delta. WSRCTR-99-00488. Aiken, SC.

Katsenovitch, Yelena. 2009. Appendix T6-003 Experimental Studies of the Transport Parameters of Mercury (II) in Oak Ridge Reservation (ORR) Soil. Technical Report Prepared for U.S. Department of Energy.

Law, G.S., and Tasker G.D., 2003, Flood-Frequency Prediction Methods for Unregulated Streams of Tennessee, 2000: U.S. Geological Survey, Water-Resources Investigations Report 03-4176, 79p.

Lee, Y., Borg, G. C., Iverfeldt, A. and H. Hultberg. 1994. Fluxes and turnover of methylmercury mercury pools in forest soils. In Mercury Pollution: Integration and Synthesis. 
Lietzke, D. A., S. Y. Lee, T. Tamura. 1986. Resource Management Plan for the Oak Ridge Reservation, Volume 20: Soil Conservation Plan for the Oak Ridge Reservation. ORNL/ESH-1/V20.

Lyon, B. F., Ambrose, R., Rice, G. and C. J. Maxwell. 1997. "Calculation of Soil- Water and Benthic Sediment Partition Coefficients for Mercury", Chemosphere, Vol.35, No. 4, pp. 791-808.

Martin (1988) In: Seiler G. and Siegel H. (Eds), Handbook of toxicity of inorganic compounds. New York: Marcel Dekker, p 14.

Moore, G. K. 1988. Concepts of Groundwater Occurrence and Flow near Oak Ridge National Laboratory, Tennessee. ORNL/TM-10969, Martin Marietta Energy Systems, Inc., Oak Ridge, Tennessee.

Moore, G. K. 1988. Groundwater parameters and flow systems near Oak Ridge National Laboratory, ORNL/TM-11368. Oak Ridge National Laboratory.

Moore, J. W. and S. Ramamodoray. 1984. Heavy Metal in Natural Waters- Applied Monitoring in Impact Assessment, Springer-Verlag, NewYork.

NC DENR. 2004. North Carolina Department of Environment and Natural Resources. Total Maximum Daily Load for Mercury in the Cashie River, North Carolina. Public Review Draft 7/28/2004

NOAA (National Oceanic and Atmospheric Administration). 2006. Local Climatological Data Annual Survey with Comparative Data, Oak Ridge, Tenn. National Oceanic and Atmospheric Administration, National Climatic Data Center, Asheville, NC.

Oak Ridge National Laboratory (ORNL), 2006. Oak Ridge Y-12 Plant, and East Tennessee Technology Park. Oak Ridge Reservation. Annual Site Environmental Report for 2005. Prepared for the U.S. Department of Energy. September 2006. Report\#DOE/ORO/2218. Available from URL: http://www.ornl.gov/aser

Oak Ridge National Laboratory (ORNL). 1992. Status Report on the Geology of the Oak Ridge Reservation. Prepared for the Office of Environmental Restoration and Waste Management, U.S. Department of Energy. October 1992. Publication No. 3860 .

Oakes, T. W. to Wing, J. F. (Letter). 1983a. Department of Energy/Oak Ridge Operations. Mercury in Soil and Sediment at ORNL.

Oakes, T. W. to Wing, J. F. (Letter). 1983b. Department of Energy/Oak Ridge Operations. Mercury in Soil Samples at ORNL. 
Parr, P. D. and J. F. Hughes. 2006. Oak Ridge Reservation Physical Characteristics and Natural Resources. ORNL/TM-2006/110.

Refsgaard, J. C.and B. Storm. 1995. In: Singh, V. P., (Ed.), Computer Models of Watershed Hydrology, Water Resources Publications, Englewood, USA, pp. 809846.

Rivers, J. M., Nyquist, J. E., Roh, Y., Terry, D. O. and W. E. Doll. 2004. Investigation into the Origin of Magnetic Soils on the Oak Ridge Reservation, Tennessee. Soil Sci. Soc. Am. J. 68, p.1772-1779.

Robinson, K. G. and M. S. Shuman. 1989. Determination of mercury in surface waters using an optimized cold vapor spectrophotometric technique. International Journal of Environmental Chemistry, 36, 111-123.

Roelant, David, et al. Remediation and Treatment Technology Development and Support for DOE/ORR. Year-End Technical Report prepared for U.S. DOE Office of Environmental Management. Florida International University, 2009.

Sarkar, D., M. E. Essington, et al. (1999). "Adsorption of Mercury (II) by Variable Charge Surfaces of Quarz and Gibbsite." Soil Science Society of America Journal, 63: 1626-1636.

Sarkar, D., M. E. Essington, et al. (2000). "Adsorption of Mercury (II) by Kaoline." Soil Science Society America Journal, 64: 1968-1975.

Schlüter, K. 1997. Sorption of Inorganic Mercury and Monomethyl Mercury in an IronHumus Podzol Soil of Southern Norway Studied by Batch Experiments. Environmental Geology, 30(3/4), p. 266-279.

Scurlock, J. M. O., Asner, G. P. and S. T. Gower. 2001. Worldwide historical estimates of Leaf Area Index, 1932-2000. Office of Scientific and Technical Information, Oak Ridge, TN, USA, Report ORNL/TM-2001/268.

Scurlock, J. M. O., Asner, G. P. and S. T. Gower. 2001. Worldwide historical estimates of Leaf Area Index, 1932-2000. Office of Scientific and Technical Information, Oak Ridge, TN, USA, Report ORNL/TM-2001/268.

Solomon, D. K., Moore G. K., Toran, L. E., Dreier, R. B., and W. M. McMaster. 1992. Status report. A Hydrological Framework for the for the Oak Ridge Reservation. ORNL/TM/12026.

Taylor, Jr., F. G. 1989. Mercury Assessment for Water and Sediment in Oak Ridge National Laboratory Streams. U.S. DOE Oak Ridge National Laboratory, Oak Ridge, Tennessee. Report \# ORNL/M-713. 
Tennessee Spatial Data Server, Available from URL: http://www.tngis.org/frequently_accessed_data.html

Tennessee Valley Authority (TVA). 1972. Upper Bear Creek Experimental Project: A Continuous Daily Streamflow Model. Research Paper No. 8, Tennessee Valley Authority Division of Water Control Planning, Knoxville, Tennessee.

Turner RR, Olsen CR, Wilson Jr WJ. Environmental fate of Hg and 137 Cs discharged from Oak Ridge facilities. In: Hemphill DD, editor. Trace substances in the environment. New York: Elsevier/North-Holland Biomed. Press: 1985.

US DOE. 1999. Remedial Investigation/Feasibility Study for Bethel Valley Watershed at Oak Ridge National Laboratory, Oak Ridge, Tennessee. Report\# DOE/OR/011748/V1\&D2.

US Environmental Protection Agency. 2007. Ecoregions of Tennessee. Available from URL: http://www.epa.gov/wed/pages/ecoregions/tn_eco.htm

USGS, 2007. Tennessee StreamStats. Available at URL: http://streamstats.usgs.gov/tnstreamstats/index.asp

USGS. 1989. Guide for Selecting Manning's Roughness Coefficients for Natural Channels and Flood Plains United States Geological Survey. Water Supply Paper 2339. Washington DC. US Government Printing Office

Van Genuchten, M., Th. 1976. A closed-form equation for predicting the hydraulic conductivity of unsaturated soils. Soil Sci Soc. J., 44(5), 892-898.

Watson, D. B., Kostka, J. E., Fields, M. W. and P. M. Jardine. 2004. The Oak Ridge Field Research Center Conceptual Model. NABIR Field Research Center Technical Report, Oak Ridge, Tennessee. Available from URL: http://public.ornl.gov/nabirfrc/other/frcconmod.pdf

Wolock, D.M., 2003a, Flow characteristics at U.S. Geological Survey streamgages in the conterminous United States: U.S. Geological Survey Open-File Report 03-146, digital data set, available at URL http://water.usgs.gov/lookup/getspatial?qsitesdd

Wolock, D.M., 2003b, Base-flow index grid for the conterminous United States: U.S. Geological Survey Open-File Report 03-263, digital data set, available at URL: http://water.usgs.gov/lookup/getspatial?bfi48grd 
Wood, A. W., Bernknopf, R., Rytuba, J.. Singer, D.A., Champion, R. 2005. Offsetbased Decision Support Models for Mitigating Mercury Sources in the Cache Creek Watershed, North Central California. Proceedings of the Water Environment Federation, National TMDL Science and Policy 2005 , pp. 1496$1516(21)$.

Y-12 Fact Sheet. http://www.y12.doe.gov/about/factsheet.php. Maintained by B\&W Y12, 2009. Accessed March 2008.

Yin, Y., H. E. Allen, et al. (1996). "Adsorption of Mercury (II) by Soil: Effects of pH, Chloride, and Organic Matter." Journal of Environmental Quality, 25: 837-844. 
APPENDICES

Table 10 Flow duration statistics for EFPC

\begin{tabular}{|ccc|}
\hline Parameter & Value & Units \\
\hline 1_Percent_Duration & 370.8 & cfs \\
\hline 5_Percent_Duration & 129 & cfs \\
\hline 10_Percent_Duration & 83 & cfs \\
\hline 20_Percent_Duration & 56 & cfs \\
\hline 25_Percent_Duration & 49 & cfs \\
\hline 30_Percent_Duration & 44 & cfs \\
\hline 40_Percent_Duration & 36 & cfs \\
\hline 50_Percent_Duration & 31 & cfs \\
\hline 60_Percent_Duration & 27 & cfs \\
\hline 70_Percent_Duration & 24 & cfs \\
\hline 75_Percent_Duration & 23 & cfs \\
\hline 80_Percent_Duration & 22 & cfs \\
\hline 90_Percent_Duration & 20 & cfs \\
\hline 95_Percent_Duration & 18 & cfs \\
\hline 99_Percent_Duration & 17 & cfs \\
\hline All data from: Rivers et al., 2004 & \\
\hline
\end{tabular}

Table 11 Annual flow statistics for EFPC

\begin{tabular}{|ccc|}
\hline Parameter & Value & Units \\
\hline Daily_flow_years & 19 & years \\
\hline Mean_Annual_Flow & 53.2 & cfs \\
\hline Stand_Dev_of_Mean_Annual_Flow & 11.4 & cfs \\
\hline All data from: Moore, 1988 & & \\
\hline
\end{tabular}

Table 12 Monthly flow statistics for EFPC

\begin{tabular}{|ccc|}
\hline Parameter & Value & Units \\
\hline April_Mean_Flow & 62.1 & cfs \\
\hline April_STD & 28.1 & cfs \\
\hline August_Mean_Flow & 31.7 & cfs \\
\hline August_STD & 8.05 & cfs \\
\hline December_Mean_Flow & 68.4 & cfs \\
\hline December_STD & 34.6 & cfs \\
\hline February_Mean_Flow & 70.9 & cfs \\
\hline February_STD & 26.9 & cfs \\
\hline
\end{tabular}




\begin{tabular}{|ccc|}
\hline January_Mean_Flow & 75.2 & cfs \\
\hline January_STD & 30.3 & cfs \\
\hline July_Mean_Flow & 44.7 & cfs \\
\hline July_STD & 45.3 & cfs \\
\hline June_Mean_Flow & 40.3 & cfs \\
\hline June_STD & 13.5 & cfs \\
\hline March_Mean_Flow & 91.1 & cfs \\
\hline March_STD & 39.7 & cfs \\
\hline May_Mean_Flow & 49 & cfs \\
\hline May_STD & 28.5 & cfs \\
\hline November_Mean_Flow & 45.8 & cfs \\
\hline November_STD & 33.9 & cfs \\
\hline October_Mean_Flow & 30.9 & cfs \\
\hline October_STD & 11.4 & cfs \\
\hline September_Mean_Flow & 28.8 & cfs \\
\hline September_STD & 8.71 & cfs \\
\hline All data from: Moore, 1988 & & \\
\hline
\end{tabular}

Table 13 General flow statistics for EFPC

\begin{tabular}{|ccc|}
\hline Parameter & Value & Units \\
\hline Average_daily_streamflow & 49.803 & cfs \\
\hline Maximum_daily_flow & 1790 & cfs \\
\hline Minimum_daily_flow & 12 & cfs \\
\hline Std_Dev_of_daily_flows & 77.92 & cfs \\
\hline All data from: Rivers et al., 2004 & \\
\hline
\end{tabular}

Table 14 Baseflow statistics for EFPC

\begin{tabular}{|ccc|}
\hline Parameter & Value & Units \\
\hline Average_BFI_value & 0.558 & dimensionless \\
\hline Number_of_years_to_compute_BFI & 27 & years \\
\hline Std_dev_of_annual_BFI_values & 0.073 & dimensionless \\
\hline All data from: Robinson and Shuman, 1989 & \\
\hline
\end{tabular}

Table 15 River network and MIKE SHE coupling branches

\begin{tabular}{|ccccc|}
\hline Branch Name & $\begin{array}{c}\text { US. } \\
\text { Chaninage }\end{array}$ & $\begin{array}{c}\text { DS. } \\
\text { Chainage }\end{array}$ & Conductance & $\begin{array}{c}\text { Leakage } \\
\text { Coefficient }\end{array}$ \\
\hline BC-A-N01 & 0 & 2627.009 & Aquifer + Bed & $1.00 \mathrm{E}-06$ \\
\hline
\end{tabular}




\begin{tabular}{|c|c|c|c|c|}
\hline BC-A-S01 & 0 & 1679.789 & Aquifer + Bed & $1.00 \mathrm{E}-06$ \\
\hline Bear Creek & 0 & 12393.2 & Aquifer + Bed & $1.00 \mathrm{E}-06$ \\
\hline Branch100 & 0 & 570.5153 & Aquifer + Bed & $1.00 \mathrm{E}-06$ \\
\hline Branch101 & 0 & 645.5479 & Aquifer + Bed & $1.00 \mathrm{E}-06$ \\
\hline Branch102 & 0 & 371.0575 & Aquifer + Bed & $1.00 \mathrm{E}-06$ \\
\hline Branch103 & 0 & 367.1307 & Aquifer + Bed & $1.00 \mathrm{E}-06$ \\
\hline Branch104 & 0 & 676.628 & Aquifer + Bed & $1.00 \mathrm{E}-06$ \\
\hline Branch105 & 0 & 738.474 & Aquifer + Bed & $1.00 \mathrm{E}-06$ \\
\hline Branch106 & 0 & 320.1355 & Aquifer + Bed & $1.00 \mathrm{E}-06$ \\
\hline Branch107 & 0 & 494.1946 & Aquifer + Bed & $1.00 \mathrm{E}-06$ \\
\hline Branch108 & 0 & 337.9415 & Aquifer + Bed & $1.00 \mathrm{E}-06$ \\
\hline Branch109 & 0 & 272.4182 & Aquifer + Bed & $1.00 \mathrm{E}-06$ \\
\hline Branch110 & 0 & 928.0936 & Aquifer + Bed & $1.00 \mathrm{E}-06$ \\
\hline Branch111 & 0 & 512.9622 & Aquifer + Bed & $1.00 \mathrm{E}-06$ \\
\hline Branch112 & 0 & 407.5125 & Aquifer + Bed & $1.00 \mathrm{E}-06$ \\
\hline Branch113 & 0 & 885.2734 & Aquifer + Bed & $1.00 \mathrm{E}-06$ \\
\hline Branch18 & 0 & 572.2349 & Aquifer + Bed & $1.00 \mathrm{E}-06$ \\
\hline Branch19 & 0 & 767.0324 & Aquifer + Bed & $1.00 \mathrm{E}-06$ \\
\hline Branch20 & 0 & 1508.714 & Aquifer + Bed & $1.00 \mathrm{E}-06$ \\
\hline Branch21 & 0 & 714.3443 & Aquifer + Bed & $1.00 \mathrm{E}-06$ \\
\hline Branch22 & 0 & 434.2925 & Aquifer + Bed & $1.00 \mathrm{E}-06$ \\
\hline Branch23 & 0 & 733.9068 & Aquifer + Bed & $1.00 \mathrm{E}-06$ \\
\hline Branch24 & 0 & 1010.745 & Aquifer + Bed & $1.00 \mathrm{E}-06$ \\
\hline Branch25 & 0 & 574.901 & Aquifer + Bed & $1.00 \mathrm{E}-06$ \\
\hline Branch26 & 0 & 1349.794 & Aquifer + Bed & $1.00 \mathrm{E}-06$ \\
\hline Branch27 & 0 & 305.551 & Aquifer + Bed & $1.00 \mathrm{E}-06$ \\
\hline Branch28 & 0 & 1385.653 & Aquifer + Bed & $1.00 \mathrm{E}-06$ \\
\hline Branch29 & 0 & 321.9663 & Aquifer + Bed & $1.00 \mathrm{E}-06$ \\
\hline Branch30 & 0 & 1220.469 & Aquifer + Bed & $1.00 \mathrm{E}-06$ \\
\hline Branch31 & 0 & 1100.442 & Aquifer + Bed & $1.00 \mathrm{E}-06$ \\
\hline Branch32 & 0 & 1119.248 & Aquifer + Bed & $1.00 \mathrm{E}-06$ \\
\hline Branch33 & 0 & 640.3945 & Aquifer + Bed & $1.00 \mathrm{E}-06$ \\
\hline Branch34 & 0 & 394.4704 & Aquifer + Bed & $1.00 \mathrm{E}-06$ \\
\hline Branch35 & 0 & 1094.315 & Aquifer + Bed & $1.00 \mathrm{E}-06$ \\
\hline Branch36 & 0 & 555.9898 & Aquifer + Bed & $1.00 \mathrm{E}-06$ \\
\hline Branch37 & 0 & 1389.404 & Aquifer + Bed & $1.00 \mathrm{E}-06$ \\
\hline Branch38 & 0 & 258.9063 & Aquifer + Bed & $1.00 \mathrm{E}-06$ \\
\hline Branch39 & 0 & 763.9674 & Aquifer + Bed & $1.00 \mathrm{E}-06$ \\
\hline Branch40 & 0 & 349.9719 & Aquifer + Bed & $1.00 \mathrm{E}-06$ \\
\hline Branch41 & 0 & 306.8962 & Aquifer + Bed & $1.00 \mathrm{E}-06$ \\
\hline
\end{tabular}




\begin{tabular}{|c|c|c|c|c|}
\hline Branch42 & 0 & 648.6201 & Aquifer + Bed & $1.00 \mathrm{E}-06$ \\
\hline Branch43 & 0 & 410.2066 & Aquifer + Bed & $1.00 \mathrm{E}-06$ \\
\hline Branch44 & 0 & 341.9655 & Aquifer + Bed & $1.00 \mathrm{E}-06$ \\
\hline Branch45 & 0 & 345.3987 & Aquifer + Bed & $1.00 \mathrm{E}-06$ \\
\hline Branch46 & 0 & 1343.248 & Aquifer + Bed & $1.00 \mathrm{E}-06$ \\
\hline Branch47 & 0 & 491.9328 & Aquifer + Bed & $1.00 \mathrm{E}-06$ \\
\hline Branch48 & 0 & 1123.569 & Aquifer + Bed & $1.00 \mathrm{E}-06$ \\
\hline Branch49 & 0 & 613.0007 & Aquifer + Bed & $1.00 \mathrm{E}-06$ \\
\hline Branch50 & 0 & 1074.729 & Aquifer + Bed & $1.00 \mathrm{E}-06$ \\
\hline Branch51 & 0 & 1674.477 & Aquifer + Bed & $1.00 \mathrm{E}-06$ \\
\hline Branch53 & 0 & 1168.691 & Aquifer + Bed & $1.00 \mathrm{E}-06$ \\
\hline Branch54 & 0 & 614.2799 & Aquifer + Bed & $1.00 \mathrm{E}-06$ \\
\hline Branch55 & 0 & 420.9591 & Aquifer + Bed & $1.00 \mathrm{E}-06$ \\
\hline Branch56 & 0 & 1506.09 & Aquifer + Bed & $1.00 \mathrm{E}-06$ \\
\hline Branch57 & 0 & 349.039 & Aquifer + Bed & $1.00 \mathrm{E}-06$ \\
\hline Branch58 & 0 & 367.6437 & Aquifer + Bed & $1.00 \mathrm{E}-06$ \\
\hline Branch59 & 0 & 1362.674 & Aquifer + Bed & $1.00 \mathrm{E}-06$ \\
\hline Branch60 & 0 & 785.5916 & Aquifer + Bed & $1.00 \mathrm{E}-06$ \\
\hline Branch61 & 0 & 455.3194 & Aquifer + Bed & $1.00 \mathrm{E}-06$ \\
\hline Branch62 & 0 & 1090.513 & Aquifer + Bed & $1.00 \mathrm{E}-06$ \\
\hline Branch63 & 0 & 1095.6 & Aquifer + Bed & $1.00 \mathrm{E}-06$ \\
\hline Branch64 & 0 & 1783.792 & Aquifer + Bed & $1.00 \mathrm{E}-06$ \\
\hline Branch65 & 0 & 365.3412 & Aquifer + Bed & $1.00 \mathrm{E}-06$ \\
\hline Branch66 & 0 & 372.1474 & Aquifer + Bed & $1.00 \mathrm{E}-06$ \\
\hline Branch67 & 0 & 565.5998 & Aquifer + Bed & $1.00 \mathrm{E}-06$ \\
\hline Branch68 & 0 & 589.8957 & Aquifer + Bed & $1.00 \mathrm{E}-06$ \\
\hline Branch69 & 0 & 710.8594 & Aquifer + Bed & $1.00 \mathrm{E}-06$ \\
\hline Branch70 & 0 & 604.1159 & Aquifer + Bed & $1.00 \mathrm{E}-06$ \\
\hline Branch71 & 0 & 603.7158 & Aquifer + Bed & $1.00 \mathrm{E}-06$ \\
\hline Branch72 & 0 & 466.2401 & Aquifer + Bed & $1.00 \mathrm{E}-06$ \\
\hline Branch73 & 0 & 1553.593 & Aquifer + Bed & $1.00 \mathrm{E}-06$ \\
\hline Branch74 & 0 & 957.999 & Aquifer + Bed & $1.00 \mathrm{E}-06$ \\
\hline Branch75 & 0 & 565.6058 & Aquifer + Bed & $1.00 \mathrm{E}-06$ \\
\hline Branch76 & 0 & 386.094 & Aquifer + Bed & $1.00 \mathrm{E}-06$ \\
\hline Branch77 & 0 & 757.1665 & Aquifer + Bed & $1.00 \mathrm{E}-06$ \\
\hline Branch78 & 0 & 1180.437 & Aquifer + Bed & $1.00 \mathrm{E}-06$ \\
\hline Branch79 & 0 & 747.8143 & Aquifer + Bed & $1.00 \mathrm{E}-06$ \\
\hline Branch80 & 0 & 656.3352 & Aquifer + Bed & $1.00 \mathrm{E}-06$ \\
\hline Branch81 & 0 & 1061.413 & Aquifer + Bed & $1.00 \mathrm{E}-06$ \\
\hline Branch82 & 0 & 455.7928 & Aquifer + Bed & $1.00 \mathrm{E}-06$ \\
\hline
\end{tabular}




\begin{tabular}{|ccccc|}
\hline Branch83 & 0 & 459.7968 & Aquifer + Bed & $1.00 \mathrm{E}-06$ \\
\hline Branch84 & 0 & 1335.563 & Aquifer + Bed & $1.00 \mathrm{E}-06$ \\
\hline Branch85 & 0 & 253.1162 & Aquifer + Bed & $1.00 \mathrm{E}-06$ \\
\hline Branch86 & 0 & 1598.993 & Aquifer + Bed & $1.00 \mathrm{E}-06$ \\
\hline Branch87 & 0 & 1219.094 & Aquifer + Bed & $1.00 \mathrm{E}-06$ \\
\hline Branch88 & 0 & 1504.984 & Aquifer + Bed & $1.00 \mathrm{E}-06$ \\
\hline Branch89 & 0 & 602.005 & Aquifer + Bed & $1.00 \mathrm{E}-06$ \\
\hline Branch90 & 0 & 776.6201 & Aquifer + Bed & $1.00 \mathrm{E}-06$ \\
\hline Branch91 & 0 & 508.74 & Aquifer + Bed & $1.00 \mathrm{E}-06$ \\
\hline Branch92 & 0 & 619.2092 & Aquifer + Bed & $1.00 \mathrm{E}-06$ \\
\hline Branch93 & 0 & 696.9681 & Aquifer + Bed & $1.00 \mathrm{E}-06$ \\
\hline Branch94 & 0 & 628.9183 & Aquifer + Bed & $1.00 \mathrm{E}-06$ \\
\hline Branch95 & 0 & 643.7243 & Aquifer + Bed & $1.00 \mathrm{E}-06$ \\
\hline Branch96 & 0 & 574.7264 & Aquifer + Bed & $1.00 \mathrm{E}-06$ \\
\hline Branch97 & 0 & 643.2892 & Aquifer + Bed & $1.00 \mathrm{E}-06$ \\
\hline Branch98 & 0 & 608.2769 & Aquifer + Bed & $1.00 \mathrm{E}-06$ \\
\hline Branch99 & 0 & 568.2906 & Aquifer + Bed & $1.00 \mathrm{E}-06$ \\
\hline EFPC & 0 & 25485.2 & Aquifer + Bed & $1.00 \mathrm{E}-06$ \\
\hline EFPC-A-N01 & 0 & 1820.508 & Aquifer + Bed & $1.00 \mathrm{E}-06$ \\
\hline EFPC-A-N02 & 0 & 1546.164 & Aquifer + Bed & $1.00 \mathrm{E}-06$ \\
\hline EFPC-A-N03 & 0 & 1616.786 & Aquifer + Bed & $1.00 \mathrm{E}-06$ \\
\hline EFPC-A-N04 & 0 & 2934.288 & Aquifer + Bed & $1.00 \mathrm{E}-06$ \\
\hline EFPC-A-N04- & 0 & 1611.753 & Aquifer + Bed & $1.00 \mathrm{E}-06$ \\
N01 & & & & \\
\hline EFPC-A-S01 & 0 & 2243.133 & Aquifer + Bed & $1.00 \mathrm{E}-06$ \\
\hline EFPC-A-S02 & 0 & 1435.423 & Aquifer + Bed & $1.00 \mathrm{E}-06$ \\
\hline EFPC-A-S03 & 0 & 1671.922 & Aquifer + Bed & $1.00 \mathrm{E}-06$ \\
\hline EFPC-A-S04 & 0 & 2272.142 & Aquifer + Bed & $1.00 \mathrm{E}-06$ \\
\hline GHB-A-S05 & 0 & 1829.85 & Aquifer + Bed & $1.00 \mathrm{E}-06$ \\
\hline Gum Hollow & 0 & 4259.921 & Aquifer + Bed & $1.00 \mathrm{E}-06$ \\
\hline Branch & 0 & 3414.32 & Aquifer + Bed & $1.00 \mathrm{E}-06$ \\
\hline Milton Branch & 0 & 2016.485 & Aquifer + Bed & $1.00 \mathrm{E}-06$ \\
\hline Pinhook Branch & 0 & & & \\
\hline
\end{tabular}




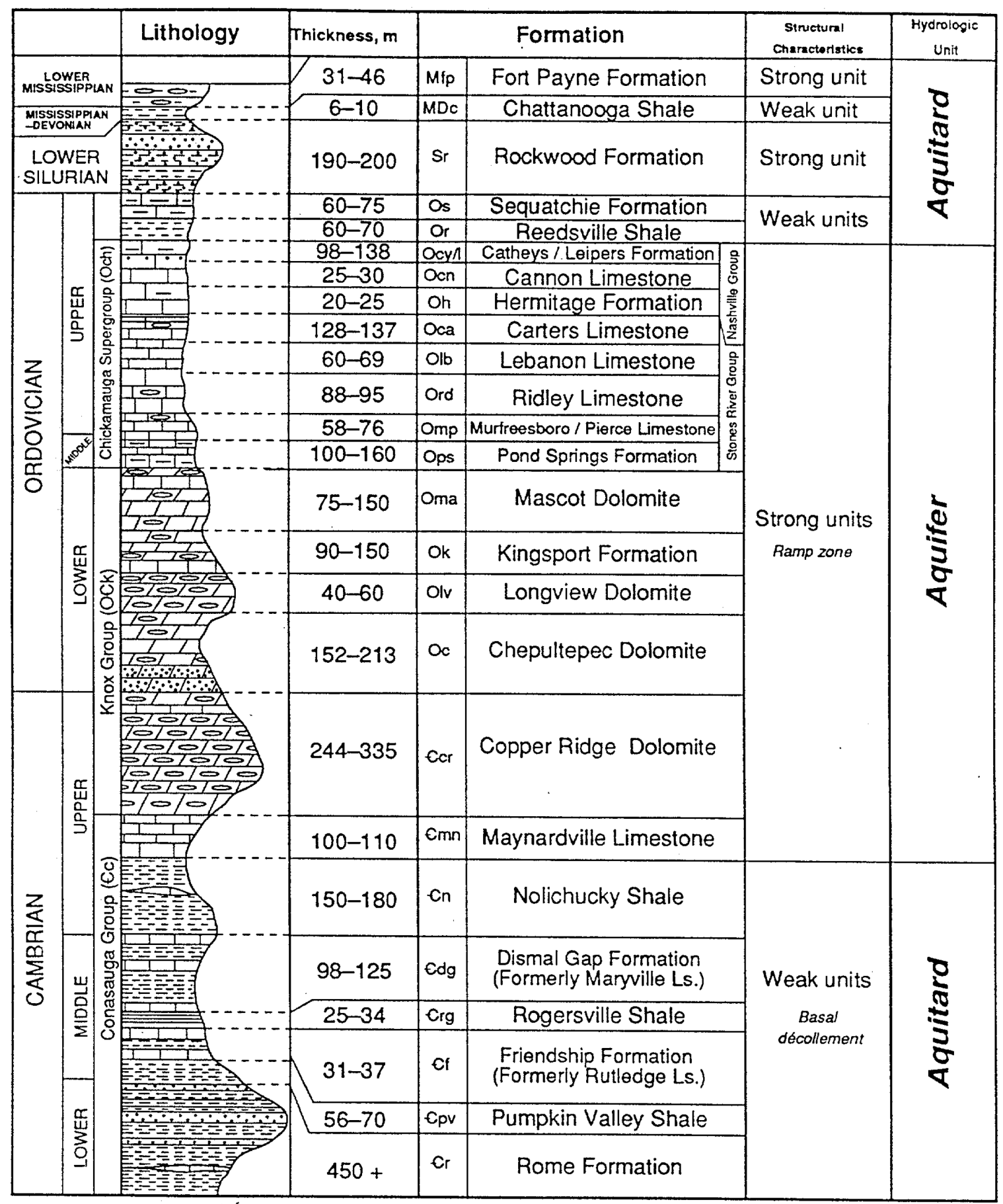

Figure 51 Typical stratigraphic section for EFPC watershed (ORNL, 1992) 